\title{
9. SITE 310: HESS RISE
}

\author{
The Shipboard Scientific Party ${ }^{1}$
}

\section{SITE DATA}

Date Occupied: 19 September 1973 (2219)

Date Departed: 24 September 1973 (1355)

Time on Site: 111 hours

Position: $36^{\circ} 52.11^{\prime} \mathrm{N}, 176^{\circ} 54.09^{\prime} \mathrm{E}$

Water Depth: 3516 corrected meters (echo sounding)

Bottom Felt With Drill Pipe At: 3524 meters below rig floor

Penetration: 352.5 meters

Number of Holes: 2

Number of Cores: 39

Total Length of Cored Section: 357 meters

Total Core Recovered: 173.1 meters

\section{BACKGROUND AND OBJECTIVES}

The principal reason for coring on rises and plateaus is to obtain fossiliferous sediment for the establishment of standard sections for biostratigraphy. These elevated areas of the sea floor are more likely to have planktonic calcareous and siliceous microfossils in their sediments than are the abyssal sea floors of equivalent latitudes and ages. Hess Rise is less well surveyed than OntongJava Plateau and Shatsky Rise, but like those two and other plateaus, it appears to be broken into blocks by normal faulting. In general, the sediment cover is about 0.3 to $0.4 \mathrm{sec}$ of seismic reflection time in thickness and has two major reflectors in the section (Davies et al., 1971).

Although an aim is to core a section on Hess Rise continuously from the sea floor into basement, there are some parts of the geologic column that are of special interest at this site. The highest of these is the Neogene section. It is anticipated that Hess Rise may provide the best possible record of the Central North Pacific Water Mass during the past few millions of years. To date there is no adequate record of the planktonic floras and faunas of this second largest of all surface-water masses. Two other Cenozoic times of particular interest are the early Miocene, which is represented by an unconformity

'Roger L. Larson, Lamont-Doherty Geological Observatory, Palisades, New York (Co-chief scientist); Ralph Moberly, Hawaii Institute of Geophysics, Honolulu, Hawaii (Co-chief scientist); David Bukry, U.S. Geological Survey, La Jolla, California; Helen P. Foreman, Oberlin College, Oberlin, Ohio; James V. Gardner, Scripps Institution of Oceanography, La Jolla, California; John B. Keene, Scripps Institution of Oceanography, La Jolla, California; Yves Lancelot, Lamont-Doherty Geological Observatory, Palisades, New York; Hanspeter Luterbacher, Esso Production Research-European, Begles, France; Monte C. Marshall, U. S. Geological Survey, Menlo Park, California; Albert Matter, Universitat Bern, Bern, Switzerland.

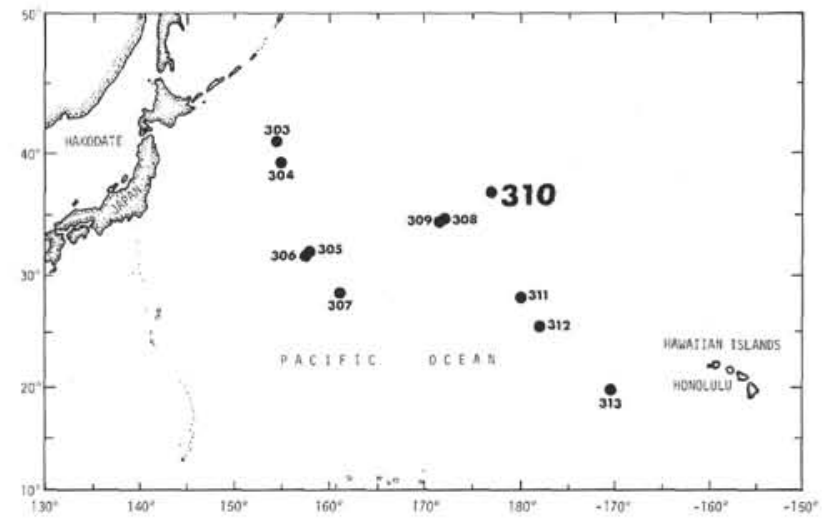

over much of the northwestern Pacific, and the Paleocene, which is thin or absent in much of the Atlantic and Pacific. The middle stages of the Cretaceous may be represented by an equatorial assemblage of fossils, with high sedimentation rates, leading to the possibility of better discrimination of biostratigraphic zonation. The equatorial section on Hess Rise may be earlier (100 to 120 m.y.?) than any other part of the Pacific having a good chance for fossil preservation.

The carbonate sediment provided by fossil skeletons has been used for studies in addition to zoogeography and fossil morphology. In particular, the complex interrelationships of surface and deep water temperature, carbon dioxide content, water depth, and general oceanic circulation may be approached through studies of the dissolution of carbonate and of ratios of oxygen isotopes through time. Studies of calcium-carbonate compensation depths (CCD) and of isotopic temperatures are more readily understood when placed in a spatial as well as in a temporal framework, and the carbonate sections on Hess Rise will thereby be especially valuable.

If sufficient Mesozoic cores are obtained as planned, their study aided by the paleooceanographic work described above may provide insight into whether the composition of the Mesozoic ocean differed significantly from that of the Cenozoic ocean. Abundance of silica, types of cations in authigenic silicates, magnesium content of carbonates, and types of layered and framework silicates have been suggested as clues to the geochemical balance, as well as relating to such problems as intensity of weathering on land and availability of nutrients in the ocean during the Mesozoic.

Because of our inability to penetrate the cherty Mesozoic section into basement at Sites 305 and 306 on Shatsky Rise, we consider it especially important to sample the basement at Hess Rise. The basement is assumed to be basalt, but it may be of a significantly 
different type than the basalt of the abyssal crust. The rises and plateaus certainly represent a different tectonic environment than the deep sea floor. Moreover, the profile of basement on reflection records is generally smoother than is typical deep-sea basement.

We will also attempt to match reflection profiler records with the actual cored section, and also attempt to take an oriented basement core to aid in the interpretation of movements of the Pacific lithospheric plate.

\section{OPERATIONS}

We approached Hess Rise (Figure 1) from the westsouthwest on a direct track from Site 309 on Kōko Guyot (Figure 2). The proposed site on the Aries-7 track appeared satisfactory when we passed over it after slowing to 7 knots (Figure 3). We continued on course for another $15 \mathrm{~min}$, executed a Williamson turn and headed back to the site at 4 knots. At $1018 \mathrm{Z}$ on 19 September 1973 we dropped a beacon on the run in $1881 \mathrm{fm}$ of water ( $3526 \mathrm{~m}$ corrected to the rig floor).

On 23 September we ran an sonobuoy that gave a somewhat noisy and short-lived record.

We did not make a pass across the beacon upon leaving the site because of difficulty in maneuvering in the rough weather that we were experiencing. We had been blown several miles south of the beacon while pulling the pipe out of Hole $310 \mathrm{~A}$. When getting underway at 0155Z, 24 September, we turned to our new course (southeast), streamed the gear, and steamed directly away.

Table 1 is a summary of coring at Site 310 . We reached the sea floor at 3524 meters $8 \mathrm{hr}$ after we began to run in pipe. It took an extra $2 \mathrm{hr}$ because we had to pick up, make, break, and remake the new portion of the bottom-hole assembly whose counterpart was lost at the end of Site 309. The sea floor proved to be soft, and we cored a 5-meter interval. After the "mudline" core, we were blown off the hole, so we regained the beacon

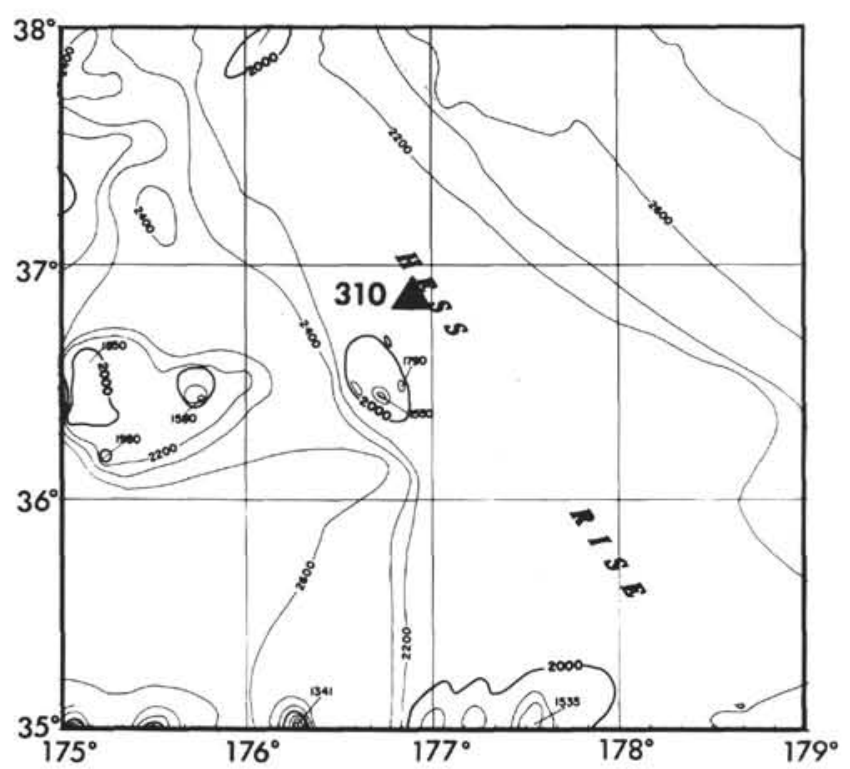

Figure 1. Bathymetry in the region of Site 310 (after Chase et al., 1971). Contour interval $200 \mathrm{fm}$ uncorrected. and respudded the hole by washing in the first 5 meters. We continuously cored Hole 310 with generally excellent recoveries down to Core 19 where we began to encounter chert of Campanian age. After Core 19 the wind began to build as a gale approached. Winds were steady at $40 \mathrm{mph}$, gusting to $50 \mathrm{mph}$. The ship maintained its position well, but it took $450 \mathrm{rpm}$ on the thrusters to manage it. The wind continued to build and at $0640 \mathrm{~L}$ on 21 September 1973 we began to pull out of the hole just after cutting Core 21 . The wind and sea were out of the south-southwest with winds of 40-50 $\mathrm{mph}$ and swells of 3 meters. To maintain position, the thrusters were reaching their maximum capacity of 600 $\mathrm{rpm}$ and threatened to overload, which would have resulted in a serious excursion from the beacon and probable loss of all the drill string in the hole.

Having continuously cored to the early Campanian at 175 meters and having at least 230 meters more section beneath, we decided to wait out the gale and redrill the hole.

By 1200L, 21 September we were in a whole gale with winds steady at $45-55 \mathrm{mph}$ and gusting to $65-70 \mathrm{mph}$. The swells were 4-4.5 meters with some breakers and green water, and a lot of blowing foam. At $1600 \mathrm{~L}$ on 21 September a cold front came through as heavy squalls. The wind then swung around to the northwest and decreased to $40 \mathrm{mph}$. This caused us to be blown out of range of the beacon because we had to maintain our heading into the heavy swells, putting the wind on our starboard beam. At $2000 \mathrm{~L}$ on 21 September the sea was

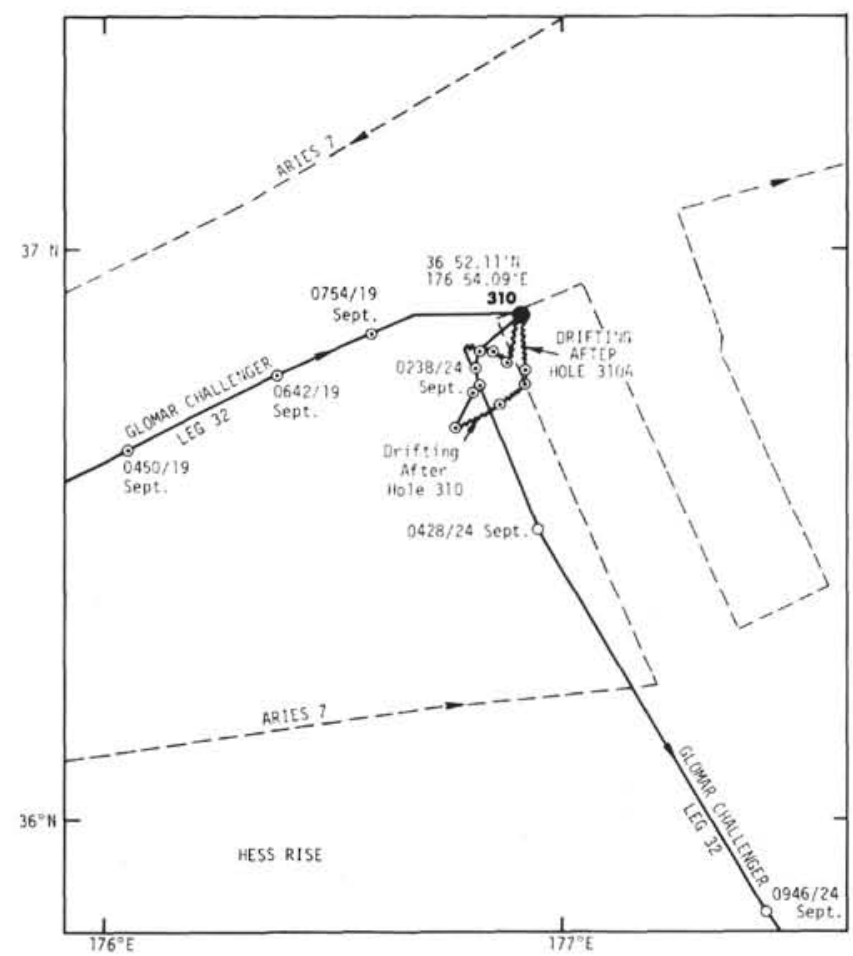

Figure 2. Track chart in the vicinity of Site 310. Solid track is Leg 32 Glomar Challenger, dashed track is Aries-7. Glomar Challenger navigation points are indicated by open circles and annotated time/day-month. 

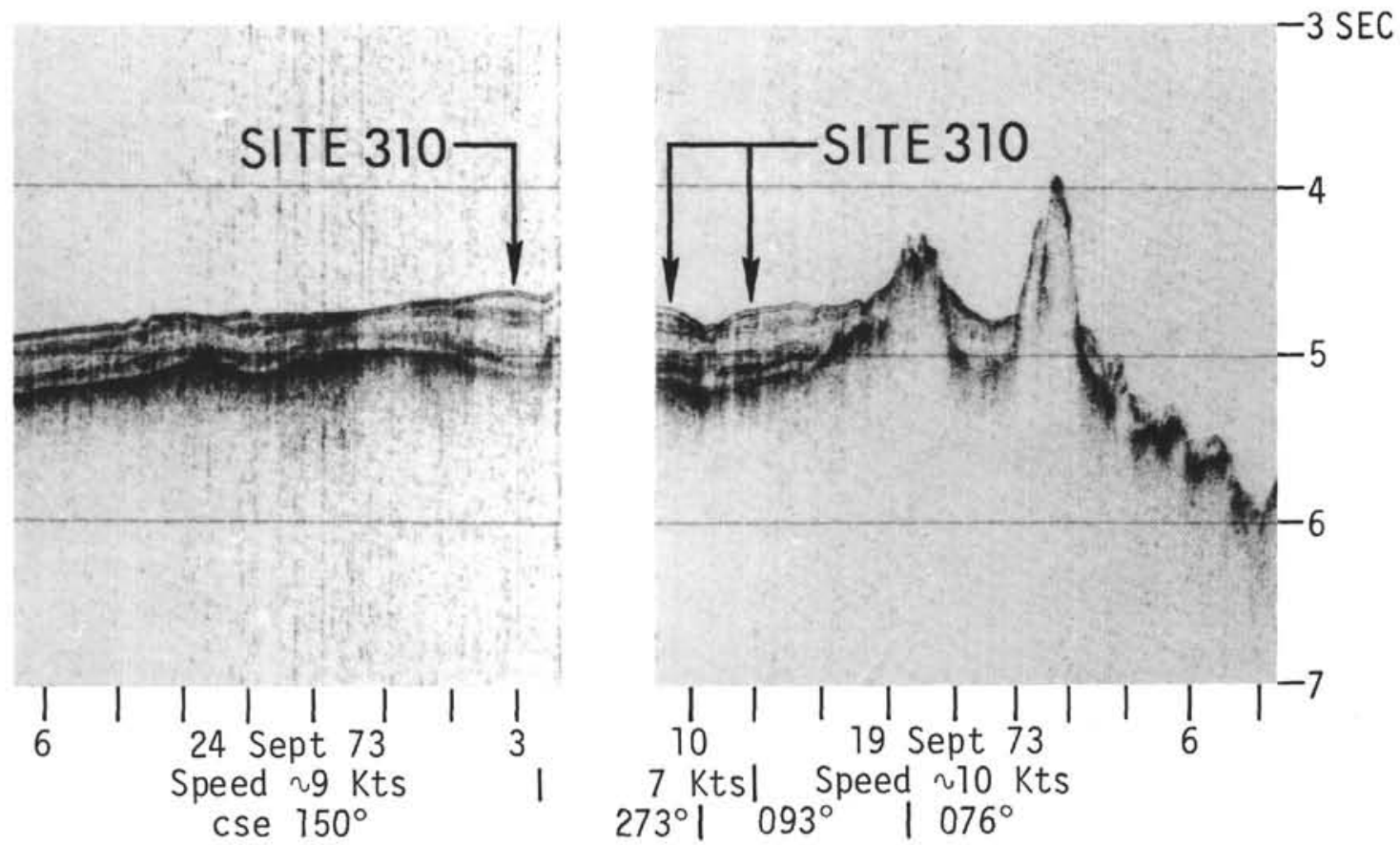

Figure 3. Seismic profiler section approaching and leaving Site 310.

somewhat calmer, and we began to retrieve the pipe to check the connections of the bottom-hole assembly.

At $0230 \mathrm{~L}$ on 22 September the bottom-hole assembly was taken on board, the joints found to be secure, and the bit in good shape. At 0430L, 22 September, we acquired a satellite fix placing us 12.5 miles south-southwest of the beacon. We then got underway at 4 knots toward the beacon. At $0715 \mathrm{~L}, 22$ September, we reacquired the beacon, and began to run in pipe for Hole $310 \mathrm{~A}$ at $0845 \mathrm{~L}$. Weather conditions at this time were much improved. There was a $20-\mathrm{mph}$ wind out of the north, the swell was confused at 2-2.5 meters, and the barometer was rising. After running in the bottom-hole assembly and five stands of pipe, we stopped running in pipe to wa t for the swells to die down. After a $2.5-\mathrm{hr}$ delay we began to run in pipe again slowly, and $8 \mathrm{hr}$ later we were at the sea floor.

We took two cores at 95-114 meters in an attempt to recover the Mesozoic-Cenozoic boundary which had fallen between cores on the first hole, and apparently missed it by coring too deeply. We began continuous coring at 184 meters in the Campanian cherts and chalks. Hole $310 \mathrm{~A}$ has very poor recoveries because it is in the Cretaceous cherty sequence. For Core 14 we attempted to improve recovery by running a springloaded, extended core barrel. This leads the bit by 4 in. in soft sediments and retracts to the level of the bit when it encounters hard material. We cut a 4.5 -meter core before hitting a hard spot and pulled the core out. We recovered 0.8 meter of soft chalks which was a vast improvement in the recovery of soft sediment. However, 1$3 / 4$ in. was milled off the end of the core-barrel extension, and the end was slightly flared because the extension was slightly longer than necessary for the bit being used. This slight flaring resulted in it being difficult to pull loose the inner core barrel.

After Core 16 was cut and retrieved at $2350 \mathrm{~L}, 23$ September, the wind began to build and gusted to 65-75 $\mathrm{mph}$. The wind continued to stay at high speeds, and we skipped two core sections in an attempt to get down the hole more quickly. While cutting Cores 17 and 18 we experienced two more 65-75 mph gusts of wind, the second of which broke the anemometer. During the second gust, the bow and one bow thruster came out of the water, allowing the bow thruster to overspeed. By the time we had restored power to the bow thruster, the ship was rolling broadside in the trough of the seas, and we had been blown $1500 \mathrm{ft}$ from the beacon. Throughout this period the hole conditions were deteriorating. The bit stuck temporarily after Core 15 and plugged during Core 17.

The wind continued to build and overwork the thrusters. We could not maintain position over the beacon except for one heading where we could not receive the beacon signal. At $0545 \mathrm{~L}, 24$ September, we were forced to pull out of the hole. We cleared the sea floor at $0700 \mathrm{~L}$ after we had been blown $1200 \mathrm{ft}$ from the beacon.

The weather forecast predicted another serious gale through the area within 24 to $36 \mathrm{hr}$, so we abandoned the site and got underway toward Site 311 .

\section{LITHOLOGIC SUMMARY}

The sedimentary section sampled at Site 310 was recovered by drilling two successive holes, 310 and $310 \mathrm{~A}$. Hole 310 was continuously cored down to 193.5 meters below the sea floor. Coring in Hole $310 \mathrm{~A}$ was initiated from 95 to 116 meters (Cores $1 \mathrm{~A}$ and $2 \mathrm{~A}$ ) in order 
TABLE 1

Coring Summary

\begin{tabular}{|c|c|c|c|c|c|c|c|}
\hline Core & $\begin{array}{l}\text { Date } \\
\text { (Sept. } \\
\text { 1973) }\end{array}$ & Time & $\begin{array}{l}\text { Depth From } \\
\text { Drill Floor } \\
(\mathrm{m})\end{array}$ & $\begin{array}{l}\text { Depth Below } \\
\text { Sea Floor } \\
\text { (m) }\end{array}$ & $\begin{array}{l}\text { Length } \\
\text { Cored } \\
\text { (m) }\end{array}$ & $\begin{array}{l}\text { Length } \\
\text { Recoverd } \\
\text { (m) }\end{array}$ & $\begin{array}{c}\text { Recovery } \\
(\%)\end{array}$ \\
\hline \multicolumn{8}{|c|}{ Hole 310} \\
\hline 1 & 20 & 0725 & $3524.0-3529.0$ & $0.0-5.0$ & 5.0 & 5.0 & 100 \\
\hline 2 & 20 & 0845 & $3529.0-3438.5$ & $5.0-14.5$ & 9.5 & 5.8 & 61 \\
\hline 3 & 20 & 0950 & $3538.5-3548.0$ & $14.5-24.0$ & 9.5 & 9.5 & 100 \\
\hline 4 & 20 & 1100 & $3548.0-3538.5$ & $24.0-33.5$ & 9.5 & 8.5 & 90 \\
\hline 5 & 20 & 1150 & $3538.5-3567.0$ & $33.5-43.0$ & 9.5 & 9.0 & 95 \\
\hline 6 & 20 & 1255 & $3567.0-3576.5$ & $43.0-52.5$ & 9.5 & 8.7 & 92 \\
\hline 7 & 20 & 1400 & $3576.5-3586.0$ & $52.5-62.0$ & 9.5 & 6.8 & 72 \\
\hline 8 & 20 & 1505 & $3586.0-3595.5$ & $62.0-71.5$ & 9.5 & 9.5 & 100 \\
\hline 9 & 20 & 1615 & $3595.5-3604.5$ & $71.5-80.5$ & 9.0 & 9.5 & 106 \\
\hline 10 & 20 & 1730 & $3604.5-3614.0$ & $80.5-90.0$ & 9.5 & 9.5 & 100 \\
\hline 11 & 20 & 1845 & $3614.0-3623.5$ & $90.0-99.5$ & 9.5 & 6.9 & 73 \\
\hline 12 & 20 & 1950 & $3623.5-3633.0$ & $99.5-109.0$ & 9.5 & 7.4 & 78 \\
\hline 13 & 20 & 2050 & $3633.0-3642.5$ & $109.0-118.5$ & 9.5 & 9.5 & 100 \\
\hline 14 & 20 & 2205 & $3642.5-3652.0$ & $118.5-128.0$ & 9.5 & 9.5 & 100 \\
\hline 15 & 20 & 2320 & $3652.0-3661.5$ & $128.0-137.5$ & 9.5 & 3.1 & 33 \\
\hline 16 & 21 & 0030 & $3661.5-3671.0$ & $137.5-147.0$ & 9.5 & 4.7 & 49 \\
\hline 17 & 21 & 0145 & $3671.0-3680.5$ & $147.0-156.5$ & 9.5 & 9.0 & 95 \\
\hline 18 & 21 & 0325 & $3680.5-3689.5$ & $156.5-165.5$ & 9.0 & 5.6 & 62 \\
\hline 19 & 21 & 0435 & $3689.5-3698.5$ & $165.5-174.5$ & 9.0 & 0.1 & 1 \\
\hline 20 & 21 & 0605 & $3698.5-3708.0$ & $174.5-184.0$ & 9.5 & 6.0 & 63 \\
\hline 21 & 21 & 0800 & $3708.0-3715.5$ & $184.0-193.5$ & 9.5 & 2.0 & 21 \\
\hline Total & & & & & 193.5 & 145.6 & 75.2 \\
\hline
\end{tabular}

Hole 310A

\begin{tabular}{rrrrrrrr}
1 & 23 & 0005 & $3619.0-3628.5$ & $95.0-104.5$ & 9.5 & 9.0 & 95 \\
2 & 23 & 0115 & $3628.5-3638.0$ & $104.5-114.0$ & 9.5 & 9.5 & 100 \\
3 & 23 & 0320 & $3708.0-3717.5$ & $184.0-193.5$ & 9.5 & 0.5 & 5 \\
4 & 23 & 0445 & $3717.5-3727.0$ & $193.5-203.0$ & 9.5 & 4.2 & 44 \\
5 & 23 & 0620 & $3727.0-3736.5$ & $203.0-212.5$ & 9.5 & 1.4 & 15 \\
6 & 23 & 0740 & $3736.5-3746.0$ & $212.5-222.0$ & 9.5 & 0.2 & 2 \\
7 & 23 & 0915 & $3746.0-3755.5$ & $222.0-231.5$ & 9.5 & 0.2 & 2 \\
8 & 23 & 1035 & $3755.5-3765.0$ & $231.5-241.0$ & 9.5 & 0.3 & 3 \\
9 & 23 & 1210 & $3765.0-3774.0$ & $241.0-250.0$ & 9.0 & 0.1 & 1 \\
10 & 23 & 1340 & $3774.0-3783.5$ & $250.0-259.5$ & 9.5 & 0.1 & 1 \\
11 & 23 & 1515 & $3783.5-3793.0$ & $259.5-269.0$ & 9.5 & 0.1 & 1 \\
12 & 23 & 1645 & $3793.0-3802.0$ & $269.0-278.0$ & 9.0 & 0.3 & 3 \\
13 & 23 & 1840 & $3802.0-3811.5$ & $278.0-287.5$ & 9.5 & 0.2 & 2 \\
14 & 23 & 2010 & $3811.5-3816.0$ & $287.5-292.0$ & 4.5 & 0.8 & 18 \\
15 & 23 & 2125 & $3821.0-3830.5$ & $297.0-306.5$ & 9.5 & trace & $<1$ \\
16 & 23 & 2350 & $3830.5-3839.5$ & $306.5-315.5$ & 9.0 & 0.2 & 2 \\
17 & 24 & 0150 & $3849.0-3858.0$ & $325.0-334.0$ & 9.0 & 0.2 & 2 \\
18 & 24 & 0500 & $3867.5-3876.5$ & $343.5-352.5$ & 9.0 & 0.2 & 2 \\
Total & & & & & 163.5 & 27.5 & 16.8 \\
\hline
\end{tabular}

to try to sample the Late Cretaceous-early Tertiary unconformity recognized in Hole 310 between Cores 11 and 12 . Then the section was drilled until the depth of the lowest core of Hole 310 was reached, and coring was continuous down to 292 meters and intermittent below (alteration of 9-m cored intervals and 9-m drilled intervals), down to 352.5 meters where the hole was abandoned due to bad weather conditions.

Recovery was generally good from the sea floor down to 165 meters (Cores 1 through 18, and also Cores 1A and $2 \mathrm{~A}$ ) because only minor chert was present in the lower part of this interval. Below that depth the combination of hard chert and relatively soft sediment (probably mainly chalk and some ooze in the uppermost cores of this interval) caused poor recovery. Again, the relative proportion of chert and other lithologies is unknown because most of the soft material was washed away under the high pump pressures required for coring of chert. A smear slide summary appears in Table 2 .

The section can be conveniently subdivided into several units and subunits, mainly using composition changes observed in smear slides and macroscopic observation of the cores. Although these subdivisions are well documented in the upper 180 meters, the detailed composition of the lower interval remains rather speculative.

The following units have been recognized (from top to bottom):

Unit 1-Radiolarian-bearing nanno ooze $(0-79 \mathrm{~m}$, Core 1 through part of Core 9). 
TABLE 2

Smear Slide Summary, Site $\mathbf{3 1 0}$

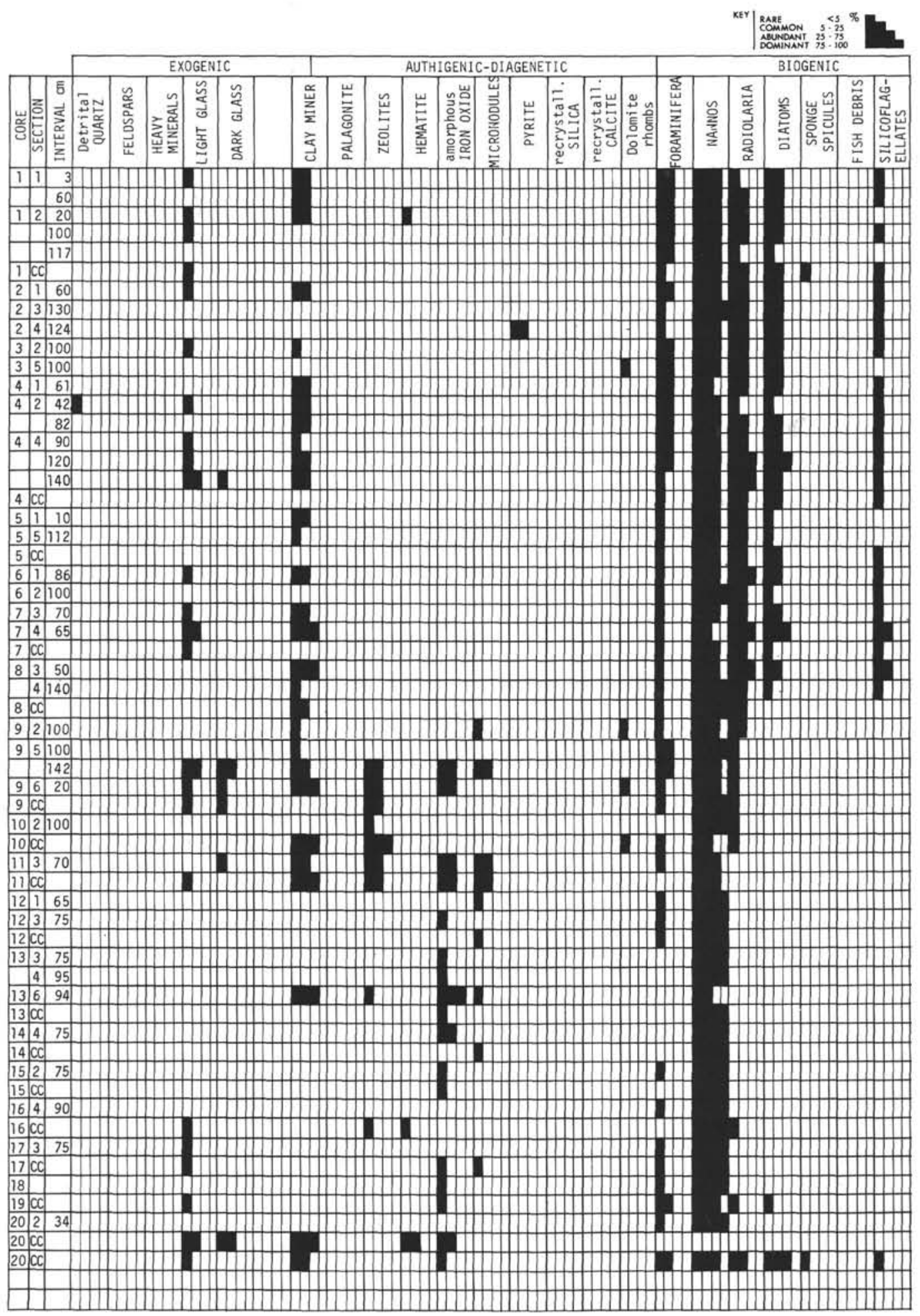




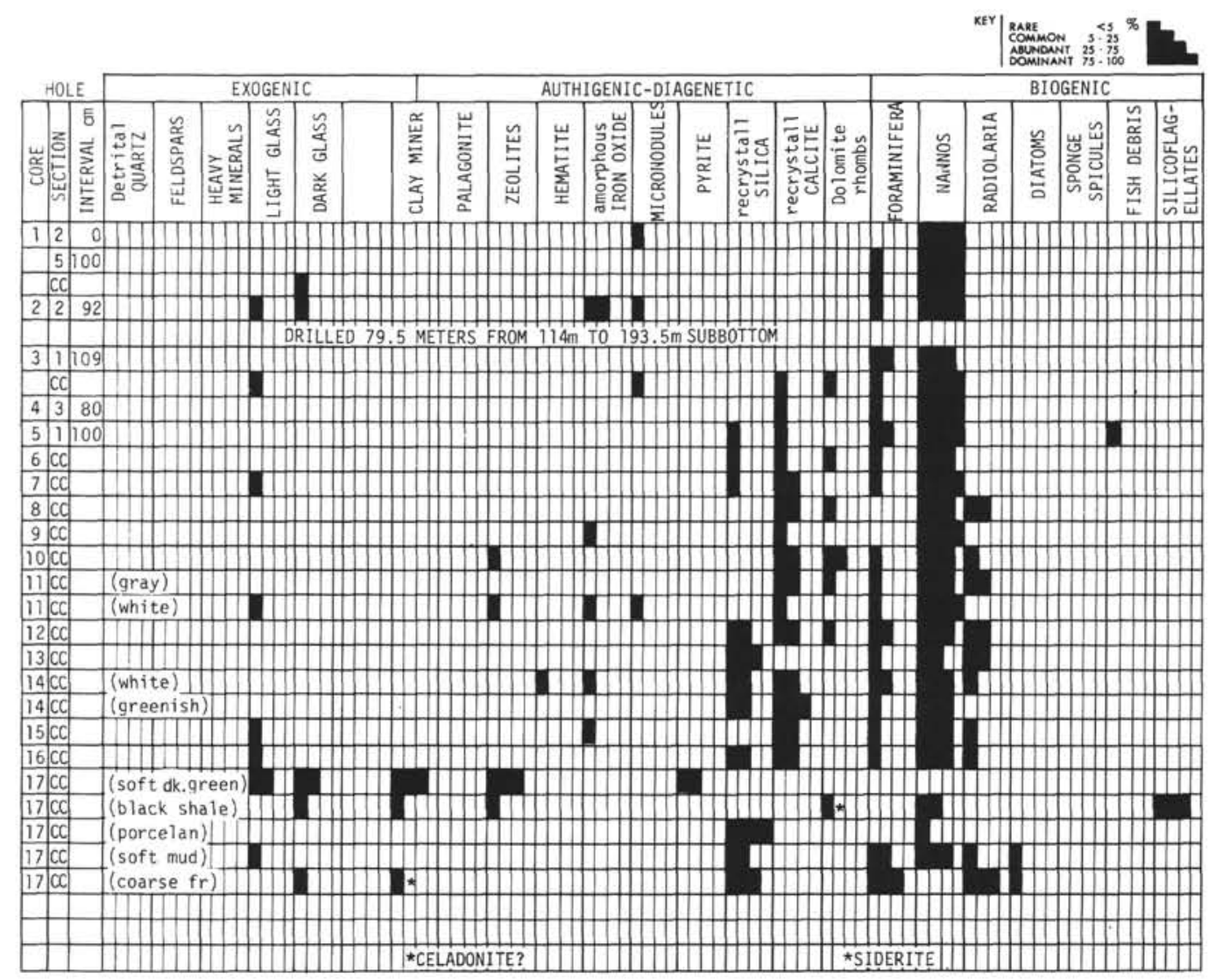

Unit 2-Nanno ooze, more or less zeolitic and nanno-bearing zeolitic pelagic clay (79-95 or $98 \mathrm{~m}$, lower part of Core 9 through Core 11).

Unit 3-Nanno ooze ( 95 or $98-128 \mathrm{~m}$, Cores 12 through 14 and Cores $1 \mathrm{~A}$ and $2 \mathrm{~A}$ ).

Unit 4-Chert, nanno ooze, and chalk with porcellanite and occasional pelagic shale (128-352 m, Cores 15 through 21 and Cores $3 \mathrm{~A}$ through 18A).

\section{Unit 1-Radiolaria-bearing Nanno Ooze (Core 1 through part of 9 )}

The sediment consists of soft, pale brown ooze generally intensely disturbed by the coring operations. The composition is rather constant and shows the predominance of biogenous, calcareous elements with abundant nannofossils and variable amounts of foraminifera decreasing regularly in the lower half of the unit. The siliceous remains, mainly radiolarians and diatoms with smaller amounts of silicoflagellates, are generally common throughout. Diatoms and silicoflagellates do not occur below Core 8 and radiolarians gradually become less abundant in Core 9. As was also noted in diatom-bearing sediments from Sites 303 and 304, the radiolarian fragments often show evidence of dissolution whereas diatoms and silicoflagellates appear relatively well preserved. Other components of the sediment consist of various proportions of clay minerals and occasional volcanic glass within relatively darker layers throughout this interval.

$\mathrm{X}$-ray diffraction analysis shows the large predominance of calcite, also reflected in the carbonate quantitative analysis (37\% to $95 \%$ with an average of $77 \%$ ). Relatively rare clay minerals are mainly mica and chlorite, which correlate with the occurrence of some quartz. These three minerals reflect a rather small but significant contribution of detrital terrigenous components to the sediment.

Organic carbon content remains very low $(0.0 \%$ to $0.2 \%$ ) throughout this unit.

Unit 2-Nanno Ooze, More or Less Zeolitic, and Nannobearing Zeolitic Pelagic Clay (lower part of Core 9 through Core 11)

The top of this unit is marked by the sudden occurrence of abundant zeolite, a lithological change which corresponds to a stratigraphic unconformity sampled in Core 9, Section 5. The sediment in the upper part of the unit consists of abundant nannofossils, common foraminifers, and rare radiolarians. Phillipsite is abundant near the top of the unit (Core 9) and decreases regularly in the white ooze found in Core 10 below another unconformity observed at the base of Core 9 . Phillipsite crystals are generally large (up to $300 \mu \mathrm{m}$ ), well crystallized and commonly show characteristic twinning. Other components of probable volcanic origin consist of clay minerals, volcanic glass, and amorphous iron oxide.

Another unconformity was sampled in Core 10 , Section 6 (early Oligocene to middle Eocene). It corresponds with a sharp boundary between slightly zeolitic pale orange nanno ooze and underlying dark brown nanno-bearing zeolitic pelagic clay. This lower part of 
the unit consists of very zeolitic nanno ooze and nannobearing zeolitic pelagic clay. Carbonate content for the whole unit ranges from $20 \%$ to $97 \%$ with an average of $55.5 \%$. Organic carbon content is nil except at the very top of the unit $(0.1 \%)$.

\section{Unit 3-Nanno Ooze (Cores 12 through 14 and Cores $1 \mathrm{~A}$ and 2A)}

The boundary between this unit and the overlying one is marked by a stratigraphic unconformity between middle to lower Eocene and Maestrichtian sediments. It is first observed (although unsampled) between Cores 11 and 12 and corresponds to a well-defined lithological change (zeolitic pelagic clay in Core 11 and nanno ooze in Core 12). Site 310A, Cores $1 \mathrm{~A}$ and $2 \mathrm{~A}$, was an attempt to core this unconformity but only the upper part of Unit 3 was recovered in these two cores. Therefore, there is some uncertainty about the actual depth of this unconformity; it lies around 95 meters (top of Core 1A) or 98 meters (bottom of Core 11).

The sediment from this unit consists of relatively pure nanno ooze, pale orange, with very rare foraminifera and various amounts of amorphous iron oxides. Apart from a thin layer $(5 \mathrm{~cm})$ of dark brown ferruginous clay, observed in Core 13, most of the color changes are only due to concentrations of amorphous iron oxides without noticeable occurrence of clay minerals or other elements of volcanic origin such as zeolites or glass shards. Clinoptilolite, however, is found in sediments from the base of Core 13 (X-ray diffraction analysis).

Unit 4-Chert and Nanno Ooze and Chalk (With Porcellanite and Occasional Pelagic Shale, Cores 15 through 21 and $3 \mathrm{~A}$ through $18 \mathrm{~A}$ )

All the chert-rich sediments are considered here as a single unit because the poor recovery of the softer sediment precludes any specific estimate of the relative amounts of the different lithologies. However, three subdivisions can tentatively be considered based on: (1) the relative abundance of chert and chalk, and (2) the nature of the sediment accompanying the chert. Because the coring of all these units was moderately rapid, the true proportion of in situ sediment is probably of chalk, ooze, clay, and shale predominating over chert and porcellanite, even though the hard rocks greatly predominated in the recoveries.

\section{Subunit 4a-Nanno Ooze and Chert (128-212.5 m, Cores 15 through 21 and Cores $3 \mathrm{~A}$ through $\mathbf{5 A}$ )}

Chert appears mainly as small fragments dispersed in a nanno ooze similar to the one occurring in the unit above. Abundant radiolarians, diatoms, and foraminifera have been found at the base of this unit (Core 21) but they are admixtures from upper parts of the hole indicating some caving.

\section{Subunit $4 \mathrm{~b}-$ Chert and Radiolarian-bearing Nanno Chalk (212.5-278 m, Cores 6A through 12A)}

In this subunit chert appears more abundant and more massive than above. Also the sediments found around the chert fragments seem more consolidated than above, and partial recrystallization of calcite is ob- served in the smear slides. Radiolarians and foraminifera are common and are often recrystallized and filled with chalcedony. Some rare scattered dolomite rhombs are found regularly in most samples.

\section{Subunit $4 c-$ Chert, Porcellanite, Chalk, Pelagic Shale, and Zeolitic Pelagic Clay (278-352.5 m, Cores 13A through 18A)}

The first hard, well-silicified calcareous porcellanite was found in Core 13A. Below this level chert was the main lithology recovered in core-catcher samples with only minor amounts of chalk and rare other lithological types. The porcellanite consists of abundant finegrained recrystallized silica (isotropic, probably disordered cristobalite) and some nannofossils with chalcedony-filled radiolarians and foraminifera often apparent under the binocular. Chalk is usually partly silicified, rich in nannofossils and recrystallized calcite, and commonly containing chalcedony-filled radiolarians and some foraminifera. In Core 17A (core-catcher sample only) small fragments of black carbonaceous pelagic shale, similar to the one sampled in the lower Upper Cretaceous sediments from Shatsky Rise, were observed. It contains abundant organic matter and some wellcrystallized rhombs of siderite. The porcellanite and the dark green zeolitic pelagic clay and mudstone found in the same core contains abundant pyrite either finely dispersed in the sediment or concentrated in thin layers. The occurrence of pyrite, siderite, and organic matter is indicative of a reducing environment possibly associated with stagnant conditions of the sea floor.

\section{Conclusions}

The nature of the sediments shows that Hess Rise has been accumulating mainly biogenous sediments above the CCD since at least the late Albian. An interval of zeolitic pelagic clay and zeolite-bearing nanno ooze associated with several probable unconformities in the lower Tertiary and uppermost Cretaceous seems to result both from a shoaling of the CCD, possibly associated with the lower productivity of the middle latitudes where the rise was supposedly located at that time (Lancelot et al., in preparation), and with an outburst of nearby volcanic activity associated with the HawaiianEmperor Seamount chain.

The overall impression from the distribution of biogenous components in the sedimentary column is in good agreement with the model of plate motion from Lancelot et al. (in preparation). The distribution of radiolarians and other siliceous microfossils is especially interesting. Radiolarians, diatoms, and silicoflagellates found in the upper part of the section probably correspond with a relatively high latitude environment during the Neogene. The time during which the site was under the middle latitudes is characterized by the large predominance of nannofossils and the absence of siliceous microfossils. The influence of the equatorial high productivity can be observed in the lower section in the Upper Cretaceous sediments where chert and radiolarians are found again. The distribution of foraminifera follows a similar pattern. 


\section{GEOCHEMICAL MEASUREMENTS}

Alkalinity, $p \mathrm{H}$, and salinity measurements for Site 310 are summarized in Table 3 and presented graphically in Figure 4 . The sediments were squeezed at $4^{\circ} \mathrm{C}$ to obtain the interstitial water. Fifteen interstitial water samples down to 179 meters (depth subbottom) were collected. Below this depth the sediment was lithified and recovery decreased. The one sample from Hole 310A was at the same depth as Sample 10 from Hole 310 and gave similar results. The results from this site are similar to those from Site 305 on Shatsky Rise.

\section{Alkalinity}

Alkalinity reaches a maximum measured value of 3.13 $\mathrm{meq} / \mathrm{kg}$ at 87.5 meters and then decreases gradually with depth to $2.15 \mathrm{meq} / \mathrm{kg}$ at 179 meters. The section sampled was nanno ooze down to 128 meters with common radiolarians in the upper part and common zeolites below. Chert and nanno ooze occur below 128 meters. The oldest sample is from the Campanian.

\section{pH}

The $p \mathrm{H}$ of the interstitial water is less than seawater for all samples and remains fairly constant with depth. Using the punch-in method, the $p \mathrm{H}$ varies from a maximum of 7.71 to 7.43 .

\section{Salinity}

The salinity of the interstitial water ranges from $35.3 \%$ to $34.3 \%$. The surface seawater salinity is $34.6 \%$.

\section{PHYSICAL PROPERTIES}

\section{Wet Bulk Density and Porosity of Soft Sediments}

The wet bulk density of the soft-stiff, moderately intensely disturbed sediments was measured continuously with the GRAPE. One or two sections per core were measured, typically Sections 2 and 5. The density of the nanno ooze increases with some fluctuations from 1.5

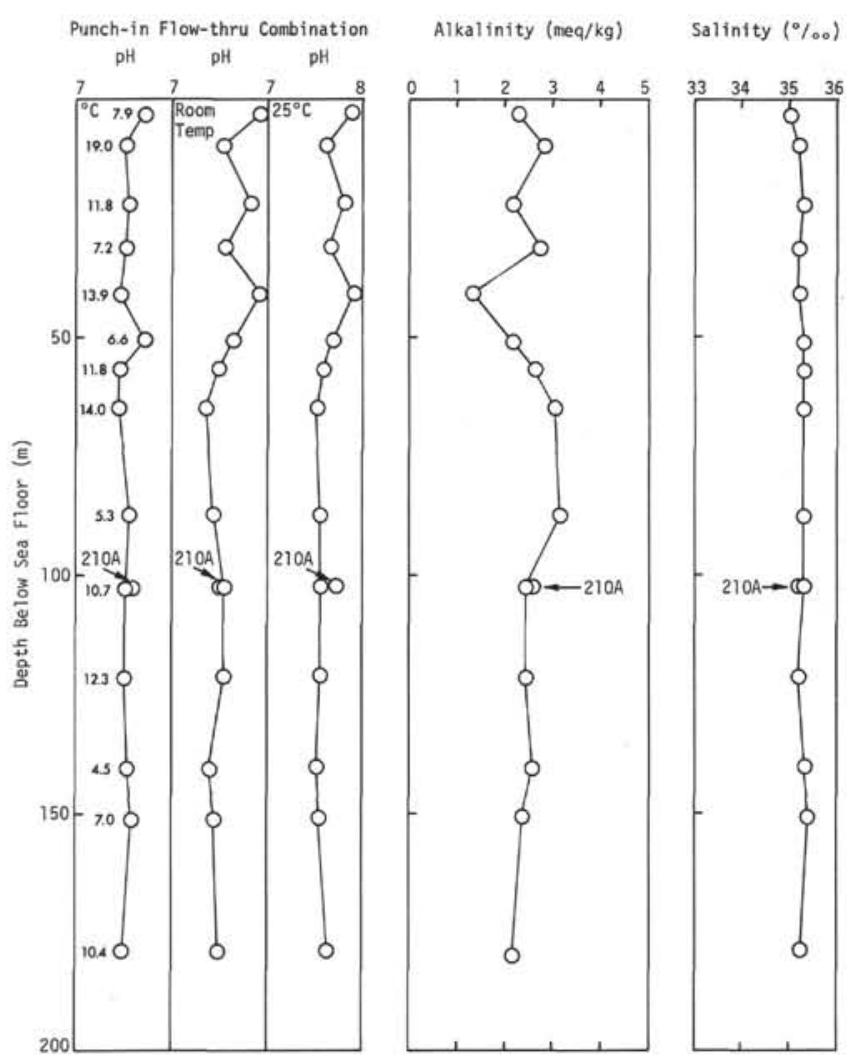

Figure 4. Graphic summary of geochemical data taken at Site 310.

$\mathrm{g} / \mathrm{cc}$ in Core 1 to $1.7 \mathrm{~g} / \mathrm{cc}$ in Core $10(90 \mathrm{~m})$. The density of the zeolitic pelagic clay in Core 11 is quite variable (due largely to drilling disturbance?) and ranges from 1.3 to $1.8 \mathrm{~g} / \mathrm{cc}$. The density of the nanno ooze for Cores 12 to $18(100-160 \mathrm{~m})$ remains fairly constant at about 1.7 $\mathrm{g} / \mathrm{cc}$. Syringe samples were usually taken from the sections measured on the GRAPE as an independent measure of bulk density and porosity. The two sets of

TABLE 3

Summary of Shipboard Geochemical Data

\begin{tabular}{lcccccc}
\hline & \multicolumn{5}{c}{$p \mathrm{H}$} \\
$\begin{array}{c}\text { Sample } \\
\text { (nterval in cm) }\end{array}$ & $\begin{array}{c}\text { Depth Below } \\
\text { Sea Floor (m) }\end{array}$ & $\begin{array}{c}\text { Punch- } \\
\text { in }\end{array}$ & $\begin{array}{c}\text { Flow- } \\
\text { through }\end{array}$ & $\begin{array}{c}\text { Alkalinity } \\
\text { (meq/kg) }\end{array}$ & $\begin{array}{c}\text { Salinity } \\
(\% \circ)\end{array}$ & Remarks \\
\hline Surface Seawater & & 8.23 & 8.27 & 2.27 & 34.6 & 8.30 \\
$1-2,144-150$ & 3 & 7.71 & 7.94 & 2.26 & 35.0 & 7.89 \\
$2-3,144-150$ & 9.5 & 7.50 & 7.53 & 2.82 & 35.2 & 7.63 \\
$3-5,144-150$ & 22 & 7.54 & 7.82 & 2.15 & 35.3 & 7.81 \\
$4-5,144-150$ & 31.5 & 7.50 & 7.54 & 2.72 & 35.2 & 7.66 \\
$5-5,144-150$ & 41.0 & 7.45 & 7.93 & 1.24 & 35.2 & 7.91 \\
$6-6,0-6$ & 50.5 & 7.71 & 7.64 & 2.17 & 35.3 & 7.68 \\
$7-3,144-150$ & 57.0 & 7.44 & 7.47 & 2.63 & 35.3 & 7.59 \\
$8-4,144-150$ & 65.0 & 7.43 & 7.35 & 3.06 & 35.3 & 7.51 \\
$10-6,0-6$ & 87.5 & 7.54 & 7.42 & 3.13 & 35.3 & 7.55 \\
$12-4,144-150$ & 102.5 & 7.50 & 7.52 & 2.44 & 35.3 & 7.54 \\
$14-4,144-150$ & 121.5 & 7.48 & 7.54 & 2.44 & 35.2 & 7.54 \\
$16-2,144-150$ & 140.5 & 7.52 & 7.38 & 2.58 & 34.3 & 7.51 \\
$18-3,144-150$ & 151.0 & 7.57 & 7.43 & 2.38 & 35.4 & 7.52 \\
$20-3,144-150$ & 179.0 & 7.47 & 7.47 & 2.15 & 35.2 & 7.62 \\
$1 \mathrm{~A}-5,144-150$ & 102.5 & 7.55 & 7.46 & 2.59 & 35.2 & 7.64 \\
\hline
\end{tabular}


density values agree within several percent. The syringe data show that the variation in wet bulk density as measured by the GRAPE is due largely to variation in porosity and not grain density. Combining the GRAPE and syringe data, the porosity of the nanno ooze decreases from $70 \%$ in Core 1 to $60 \%$ in Core $10(90 \mathrm{~m})$ and remains at about $60 \%$ down through Core $18(160 \mathrm{~m})$. The porosity of the zeolitic pelagic clay in Core 11 varies from about $55 \%-75 \%$.

\section{Sonic Velocity}

The compressional wave velocity, $V p$, of the soft-stiff, moderately intensely disturbed calcareous ooze recovered at this site is about $1.5 \mathrm{~km} / \mathrm{sec}$. The $V p$ of the stiff, zeolitic pelagic clay approaches $1.6 \mathrm{~km} / \mathrm{sec}$. Single samples of chalk and porcellanite have a $V p$ of 1.8 and $2.4 \mathrm{~km} / \mathrm{sec}$, respectively. Chert has a $V p$ of about 5.0 $\mathrm{km} / \mathrm{sec}$.

\section{CORRELATION OF SEISMIC REFLECTION PROFILES AND DRILLING RESULTS}

This correlation is based on the seismic profile (Figure 3) recorded while approaching Site 310 . The record shows an upper interval, moderately stratified, from the sea floor reflector down to about $0.24 \mathrm{sec}$. This interval overlies a reflective zone apparently stratified and within which a strong reflector can be observed at $0.32 \mathrm{sec}$ below the sea floor. The acoustic basement lies below at about $0.42 \mathrm{sec}$. This basement reflector appears fairly stratified, and it is possible that the real basement reflector lies as deep as $0.02 \mathrm{sec}$ below that level or even deeper. In fact, the relationship between the basement reflector recognized on the profile $2 \mathrm{hr}$ before reaching Site 310 where a basement high is clearly visible and the one observed at the site suggests that the actual basement could lie even slightly deeper than the basement reflector observed at the site, as the continuity of the acoustic basement is difficult to establish.

The top of the reflective zone observed at $0.24 \mathrm{sec}$ below the sea floor correlates well with the occurrence of the uppermost massive and abundant chert in the sediments at 180 meters subbottom (Core 21). Above that level only scattered small chert fragments were found in a nannofossil ooze which remained the largely dominant lithology. The interval velocity computed for the layer above this reflective zone is about $1.5 \mathrm{~km} / \mathrm{sec}$. This value is compatible with the nature of the sediment recovered in this interval (unlithified radiolarian-bearing nanno ooze) and with the shipboard measurements on the cores.

The strong reflector observed at $0.32 \mathrm{sec}$ is tentatively correlated with the occurrence of abundant porcellanite and massive chert in Core 13A at 280 meters below the sea floor, although the poor recovery generally precludes any complete and precise determination of the nature of the different lithologies present below about 200 meters subbottom. This correlation allows for an interval velocity of about $2.5 \mathrm{~km} / \mathrm{sec}$ in the chert and chalk interval observed between 180 and 280 meters subbottom.

As basement was not reached in this hole, it is not possible to determine the nature and actual depth of the acoustic basement observed on the profile. If the top part of the layered acoustic basement is supposed to correspond with the top of the basaltic basement, the latter might be at 410 to 420 meters below the sea floor when using an interval velocity of 2.5 to $2.8 \mathrm{~km} / \mathrm{sec}$ for the overlying sediments (beneath the reflector at $0.32 \mathrm{sec}$ ). If the base of the layered fraction of the acoustic basement ( $0.02 \mathrm{sec}$ below the top) is supposed to correspond with the basalt, then it could lie as deep as 430 meters (using a $2.5 \mathrm{~km} / \mathrm{sec}$ interval velocity) or 450 meters (using a 2.8 $\mathrm{km} / \mathrm{sec}$ velocity) below the sea bottom. It is also possible that the more or less layered acoustic basement could correspond with lithified sediments and that the basalt could lie even deeper than the depth indicated above.

Figure 5 summarizes these correlations.

\section{BIOSTRATIGRAPHIC SUMMARY}

The upper 95 meters, Cores 1 through 11, penetrated are Cenozoic and the remaining 95 to 352.5 meters, Cores 12 through 21 and $1 \mathrm{~A}$ through $18 \mathrm{~A}$, are Cretaceous (Table 4). The age of the oldest sediment, based on foraminifera, is early Cenomanian.

Foraminifera and coccoliths are present throughout the Cenozoic. Radiolaria, however, are present only through Core 9, Section 4, where an apparent unconformity in the lower part of Core 9 juxtaposes middle Miocene assemblages above with those of the early Oligocene below. In the Cretaceous, foraminifera and coccoliths are present throughout, and Radiolaria occur sporadically only in the lower part, Cores $8 \mathrm{~A}$ to $18 \mathrm{~A}$.

The Paleogene is represented by a very compressed section $(19 \mathrm{~m})$ in the lower part of Core 9 through Cores 11 and $1 \mathrm{~A}$. The Paleocene is missing and although two attempts were made the Eocene-Maestrichtian contact was not recovered.

Whereas the complete Neogene section could be zoned by Radiolaria and the complete Cenozoic by coccoliths, in the Cretaceous the best stratigraphic control is provided by the foraminifera (see graphic hole summary and individual group reports).

\section{Foraminifera}

Cores 1 to 3 contain abundant faunas of planktonic foraminifera showing evidence of intense carbonate solution. The assemblages which are largely dominated by Globorotalia inflata are characteristic of temperate waters. The Pleistocene/Pliocene boundary (N22/N21) is marked between Cores 3 and 4 by the lowest occurrence of Globorotalia truncatulinoides.

Cores 5 and 6 are attributed to the Pliocene, the lowermost occurrence of $G$. inflata between Sections 3 and 4 of Core 5 marking the late/early Pliocene boundary. Cores 7, 8, and upper part of Core 9 are attributed to the late Miocene. Core 9, Section 6 which contains Globorotalia praemenardii is attributed to the middle Miocene Zones N10 to N12. The core catcher of Core 9 includes a mixture of Oligocene and Miocene species.

A stratigraphic hiatus occurs between Cores 9 and 10 . Core 10 contains Oligocene assemblages and is assigned to Zones P19 to P18. 


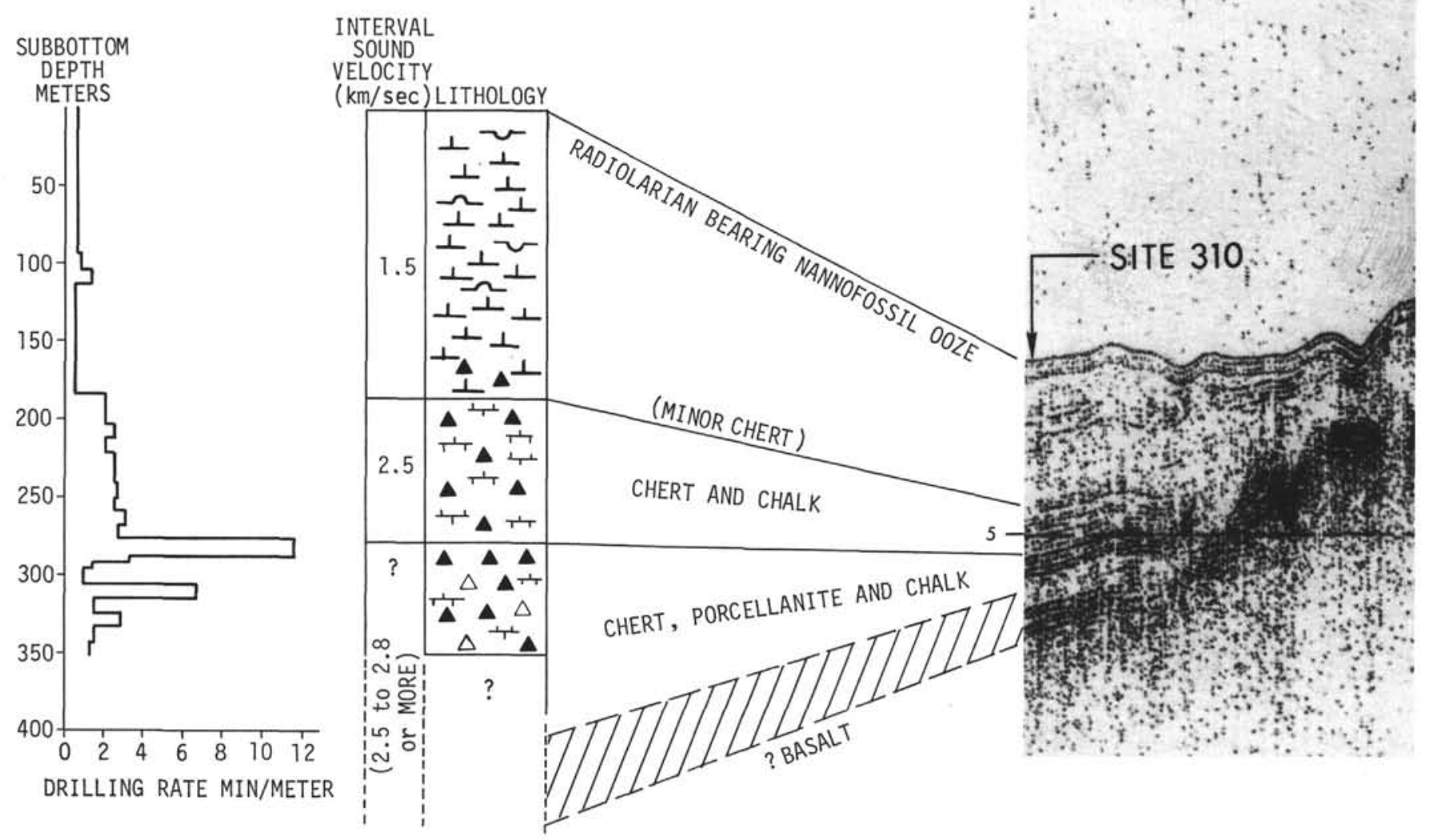

Figure 5. Correlation of seismic reflection profile with drilling results at Site 310.

TABLE 4

Distribution, Age, and Frequency of Investigated Microfossils

\begin{tabular}{|c|c|c|c|c|c|c|c|c|c|}
\hline \multirow[b]{2}{*}{ نั } & \multirow[b]{2}{*}{ Depth (m) } & \multirow{2}{*}{ 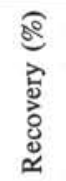 } & \multicolumn{3}{|r|}{ Foraminifera } & \multirow{2}{*}{\multicolumn{2}{|c|}{$\begin{array}{c}\text { Calcareous } \\
\text { Nannoplankton }\end{array}$}} & \multirow{2}{*}{\multicolumn{2}{|c|}{ Radiolaria }} \\
\hline & & & $\frac{\sqrt{\frac{\pi}{E}}}{\frac{\pi}{\alpha}}$ & 壱 & & & & & \\
\hline \multicolumn{10}{|c|}{ Hole 310} \\
\hline 1 & $0.0-5.0$ & 100 & o & * & Quaternary & $\bullet$ & Quaternary & o & Pleistocene \\
\hline 2 & $5.0-14.5$ & 61 & o & * & Quaternary & $\bullet$ & Quaternary & 0 & Pleistocene \\
\hline 3 & $14.5-24.0$ & 100 & $\bullet$ & * & Quaternary & $\bullet$ & Quaternary & o & $\begin{array}{l}\text { Pleistocene/ } \\
\text { Pliocene }\end{array}$ \\
\hline 4 & $24.0-33.5$ & 90 & $\bullet$ & * & Quaternary & $\bullet$ & $\begin{array}{l}\text { Quaternary and } \\
\text { Late Pliocene }\end{array}$ & 0 & Pliocene \\
\hline 5 & $33.5-43.0$ & 95 & $\bullet$ & $*$ & Pliocene & $\bullet$ & Late Pliocene & o & Pliocene \\
\hline 6 & $43.0-52.5$ & 92 & o & + & Pliocene & $\bullet$ & Pliocene & o & $\begin{array}{l}\text { Pliocene/ } \\
\text { late Miocene }\end{array}$ \\
\hline 7 & $52.5-62.0$ & 72 & o & + & Late Miocene & $\bullet$ & $\begin{array}{l}\text { Early Pliocene } \\
\text { late Miocene }\end{array}$ & * & Late Miocene \\
\hline 8 & $62.0-71.5$ & 100 & 0 & + & Late Miocene & $\bullet$ & Late Miocene & $*$ & Late Miocene \\
\hline 9 & $71.5-80.5$ & 106 & + & + & $\begin{array}{l}\text { Late/middle } \\
\text { Miocene }\end{array}$ & • & $\begin{array}{l}\text { Late/middle } \\
\text { Miocene }\end{array}$ & $*$ & Late Miocene \\
\hline 10 & $80.5-90.0$ & 100 & - & * & $\begin{array}{l}\text { Early Oligocene } \\
\text { and middle Eocene }\end{array}$ & $\bullet$ & $\begin{array}{l}\text { Early Oligocene } \\
\text { and middle Eocene }\end{array}$ & - & - \\
\hline 11 & $90.0-99.5$ & 73 & o & 0 & $\begin{array}{l}\text { Middle or } \\
\text { early Eocene }\end{array}$ & $\bullet$ & $\begin{array}{l}\text { Middle and } \\
\text { early Eocene }\end{array}$ & - & - \\
\hline
\end{tabular}


TABLE 4 - Continued

\begin{tabular}{|c|c|c|c|c|c|c|c|c|c|}
\hline \multirow[b]{2}{*}{ ठ } & \multirow[b]{2}{*}{ Depth (m) } & \multirow{2}{*}{ 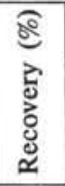 } & \multicolumn{3}{|c|}{ Foraminifera } & \multirow{2}{*}{\multicolumn{2}{|c|}{$\begin{array}{c}\text { Calcareous } \\
\text { Nannoplankton }\end{array}$}} & \multirow{2}{*}{\multicolumn{2}{|c|}{ Radiolaria }} \\
\hline & & & 胥 & 苞 & & & & & \\
\hline \multicolumn{10}{|c|}{ Hole 310} \\
\hline 12 & $99.5-109.0$ & 78 & + & 0 & $\begin{array}{l}\text { Early } \\
\text { Campanian }\end{array}$ & 0 & $\begin{array}{l}\text { Early } \\
\text { Maestrichtian }\end{array}$ & - & - \\
\hline 13 & $109.0-118.5$ & 100 & + & $*$ & $\begin{array}{l}\text { Early } \\
\text { Campanian }\end{array}$ & $\bullet$ & $\begin{array}{l}\text { Early Maestrich/ } \\
\text { late Campanian }\end{array}$ & - & - \\
\hline 14 & $118.5-128.0$ & 100 & & 0 & $\begin{array}{l}\text { Early } \\
\text { Campanian }\end{array}$ & $\bullet$ & $\begin{array}{l}\text { Early Maestrich/ } \\
\text { late Campanian }\end{array}$ & - & - \\
\hline 15 & $128.0-137.5$ & 33 & + & $*$ & $\begin{array}{l}\text { Early } \\
\text { Campanian }\end{array}$ & $\bullet$ & $\begin{array}{l}\text { Early Maestrich/ } \\
\text { late Campanian }\end{array}$ & - & - \\
\hline 16 & $137.5-147.0$ & 49 & o & $*$ & $\begin{array}{l}\text { Early } \\
\text { Campanian }\end{array}$ & 0 & $\begin{array}{l}\text { Early } \\
\text { Campanian }\end{array}$ & - & - \\
\hline 17 & $147.0-156.5$ & 95 & $\bullet$ & $*$ & $\begin{array}{l}\text { Early } \\
\text { Campanian }\end{array}$ & • & $\begin{array}{l}\text { Early } \\
\text { Campanian }\end{array}$ & - & - \\
\hline 18 & $156.5-165.5$ & 62 & $\bullet$ & $*$ & $\begin{array}{l}\text { Early } \\
\text { Campanian }\end{array}$ & $\bullet$ & $\begin{array}{l}\text { Early } \\
\text { Campanian }\end{array}$ & - & - \\
\hline 19 & $165.5-174.5$ & 1 & $\bullet$ & + & $\begin{array}{l}\text { Early } \\
\text { Campanian }\end{array}$ & $\bullet$ & $\begin{array}{l}\text { Early } \\
\text { Campanian }\end{array}$ & + & - \\
\hline 20 & $174.5-184.0$ & 63 & $\bullet$ & $*$ & $\begin{array}{l}\text { Early } \\
\text { Campanian }\end{array}$ & $\bullet$ & $\begin{array}{l}\text { Early } \\
\text { Campanian }\end{array}$ & - & - \\
\hline 21 & $184.0-193.5$ & 21 & + & + & $\begin{array}{l}\text { Early } \\
\text { Campanian }\end{array}$ & $\bullet$ & (caved) & - & - \\
\hline
\end{tabular}

Hole 310A

\begin{tabular}{|c|c|c|c|c|c|c|c|c|c|}
\hline 1 & $95.0-104.5$ & 95 & * & o & $\begin{array}{l}\text { Early } \\
\text { Campanian }\end{array}$ & • & Maestrichtian & - & - \\
\hline 2 & $104.5-114.0$ & 100 & * & o & $\begin{array}{l}\text { Early } \\
\text { Campanian }\end{array}$ & $\bullet$ & $\begin{array}{l}\text { Early Maestrich. } \\
\text { or late Campan. }\end{array}$ & - & - \\
\hline 3 & $184.0-193.5$ & 5 & + & + & $\begin{array}{l}\text { Early } \\
\text { Campanian }\end{array}$ & $\bullet$ & $\begin{array}{l}\text { Early Maestrich. } \\
\text { or late Campan. }\end{array}$ & - & - \\
\hline 4 & $193.5-203.0$ & 44 & o & + & $\begin{array}{l}\text { Early } \\
\text { Campanian }\end{array}$ & • & $\begin{array}{l}\text { Santonian/ } \\
\text { late Turonian }\end{array}$ & + & - \\
\hline 5 & $203.0-212.5$ & 15 & o & + & $\begin{array}{l}\text { Early } \\
\text { Campanian }\end{array}$ & 0 & $\begin{array}{l}\text { Santonian/ } \\
\text { late Turonian }\end{array}$ & - & - \\
\hline 6 & $212.5-222.0$ & 2 & * & + & Santonian & $\bullet$ & $\begin{array}{l}\text { Santonian/ } \\
\text { late Turonian }\end{array}$ & - & - \\
\hline 7 & $222.0-231.5$ & 2 & + & + & Santonian & $\bullet$ & $\begin{array}{l}\text { Santonian } \\
\text { late Turonian }\end{array}$ & - & - \\
\hline 8 & $231.5-241.0$ & 3 & - & - & - & $\bullet$ & $\begin{array}{l}\text { Santonian/ } \\
\text { late Turonian }\end{array}$ & 0 & - \\
\hline 9 & $241.0-250.0$ & 1 & $\bullet$ & + & Santonian & 0 & $\begin{array}{l}\text { Santonian/ } \\
\text { late Turonian }\end{array}$ & - & - \\
\hline 10 & $250.0-259.5$ & 1 & $\bullet$ & + & Santonian & $\bullet$ & $\begin{array}{l}\text { Santonian/ } \\
\text { late Turonian }\end{array}$ & 0 & - \\
\hline 11 & $259.5-269.0$ & 1 & 0 & + & Coniacian & o & $\begin{array}{l}\text { Santonian/ } \\
\text { late Turonian }\end{array}$ & o & - \\
\hline 12 & $269.0-278.0$ & 3 & * & + & Coniacian & - & - & 0 & - \\
\hline 13 & $278.0-287.5$ & 2 & 0 & 0 & (caved) & o & (caved) & 0 & - \\
\hline 14 & $287.5-292.0$ & 18 & 0 & + & Coniacian & $\bullet$ & $\begin{array}{l}\text { Early Turonian/ } \\
\text { Cenomanian }\end{array}$ & + & - \\
\hline 15 & $297.0-306.5$ & $<1$ & o & * & Turonian & $\bullet$ & $\begin{array}{l}\text { Early Turonian/ } \\
\text { Cenomanian }\end{array}$ & - & - \\
\hline 16 & $306.5-315.5$ & 2 & o & + & Turonian & * & $\begin{array}{l}\text { Early Turonian/ } \\
\text { Cenomanian }\end{array}$ & $*$ & - \\
\hline 17 & $325.0-334.0$ & 2 & + & + & Cenomanian & $\bullet$ & $\begin{array}{l}\text { Early Cenomanian/ } \\
\text { late Albian }\end{array}$ & o & - \\
\hline 18 & $343.5-352.5$ & 2 & + & + & Cenomanian & $\bullet$ & $\begin{array}{l}\text { Early Cenomanian/ } \\
\text { late Albian }\end{array}$ & $*$ & - \\
\hline
\end{tabular}

Note: - abundant; o common; * frequent; + rare; - absent. 
The lower part of Section 6 in Core 10 and Core 11 consist of predominantly dark brown clay. Planktonic foraminifera are rare and only solution-resistant species are found. They cannot be readily placed in a definite zone and only gross age determinations are possible. The lower part of Section 6 and the core-catcher sample of Core 10 are of Eocene or Oligocene age. The microfaunas of Core 11 are of middle Eocene and/or early Eocene age. Fish teeth and scales, lagenids, arenaceous foraminifera (e.g., Bathysiphon, Glomospira, Haplophragmoides) constitute the major part of the washed residues. A sample from Section $3(50-52 \mathrm{~cm})$ is relatively rich in reworked Cretaceous planktonic foraminifera.

The first Maestrichtian planktonic foraminifera are found at the top of Core 12. However, Cores 12 to 15 contain only very few planktonic foraminifera. In addition, the few specimens of Globotruncana encountered in these cores are very poorly preserved. The scarce microfaunas consist mainly of more resistant benthonic foraminifera and rather nondescript Hedbergella, Globigerinelloides, and heterohelicids and therefore cannot be attributed to a definite zone.

Starting with Core 16, the planktonic foraminiferal faunas become somewhat better, but most specimens are still damaged. Intervals lacking planktonic foraminifera are common.

In addition, recovery is generally poor and exists oftentimes only in pieces of chert and cuttings or cavings of somewhat doubtful origin.

Core 12 is attributed to the early Maestrichtian, whereas Cores 12 to 21 are of a broad Campanian age.

The few cuttings recovered as Core 21 are heavily contaminated by Pliocene and Pleistocene foraminifera.

An attempt to core the Cretaceous-Tertiary contact failed, since Core 1A is entirely of early Maestrichtian age. Core $2 \mathrm{~A}$ is developed in solution facies and contains only a few poorly preserved planktonic foraminifera of Campanian aspect.

Cores $3 \mathrm{~A}, 4 \mathrm{~A}$, and $5 \mathrm{~A}$ are of Campanian age.

The presence of Globotruncana concavata in Cores 6A, $7 \mathrm{~A}$, and $9 \mathrm{~A}$ indicates a Santonian age. The silicified chalk in Core $8 \mathrm{~A}$ is barren, except for a few poorly preserved radiolarians.

The top of the Coniacian is drawn with Core $10 \mathrm{~A}$ based on the first occurrence of Globotruncana schneegansi. Globotruncana sigali, which marks the lower part of the same stage, occurs in Core 14A.

Cores $15 \mathrm{~A}$ and 16A contain Globotruncana helvetica and are therefore attributed to the Turonian. The cuttings of Core $15 \mathrm{~A}$ are dominated by Pliocene to Pleistocene specimens.

The cuttings from Core $17 \mathrm{~A}$ are very rich in wellpreserved planktonic foraminifera of Cenomanian age. However, the microfauna is slightly contaminated by Neogene and Late Cretaceous foraminifera caved from above. Green pyritic laminated and black slightly bituminous shales in Core $17 \mathrm{~A}$ are barren.

The planktonic foraminifera obtained from lumps of soft tan shales in Core 17A are typical for the Rotalipora apenninica Zone (topmost Albian to basal Cenomanian). The cuttings from the same core have fur- nished a mixed assemblage of latest Albian to early Cenomanian age, slightly contaminated by mid-Turonian to Neogene species.

\section{Coccoliths}

\section{Cenozoic}

Quaternary to Miocene coccoliths in Cores 1 to 8 (0$72 \mathrm{~m})$ are abundant and preservation is moderate. Discoasters are common to abundant in Pliocene and Miocene Cores 4 to $8(24-72 \mathrm{~m})$, but sphenoliths are missing. The assemblages are also restricted by the rarity or absence of Discolithina, Rhabdosphaera, and Scyphosphaera. Warm-water species of Discoaster, such as the five-rayed $D$. bellus to $D$. quinqueramus plexus, are rare.

An unconformity in Core 9 (72-81 m) juxtaposes middle Miocene assemblages above those of early Oligocene age. The core-catcher sample of Core 11 contains a strongly dissolved assemblage of the Discoaster lodoensis Zone, whereas the top of Core $12(100 \mathrm{~m})$ contains a Late Cretaceous assemblage. No contact was recovered.

\section{Mesozoic}

Although Cenozoic assemblages could be routinely zoned, marker species are sparse in the Mesozoic section of Cores 12 to 21 (100-194 m) and Cores 1A to 18A (95$353 \mathrm{~m}$ ). The Campanian to Maestrichtian Tetralithus trifidus Zone occurs in Cores 13 to 15 and 2A. The Campanian Eiffellithus eximius Zone occurs in Cores 16 to 20. Coccoliths are generally abundant in the Mesozoic samples recovered but preservation is only poor to moderate. Below the Campanian, coccolith samples were often obtained only by scraping sediment encrusted on large pieces of chert. Diagenetically resistant, long-ranged species dominate such material.

Basal age of the Mesozoic section in Core 18A (344$353 \mathrm{~m}$ ) is late Albian to early Cenomanian Lithraphidites alatus Zone based on a moderately well-preserved coccolith assemblage that includes the name-giving species.

\section{Radiolaria}

\section{Neogene}

In Hole 310 Radiolaria are common and their preservation is good in Cores 1 through 6 , and few and good in Cores 7 and 9 through Section 4. Radiolaria are not present in Section 6 or the core catcher of Core 9.

In Core 1 through Core 2, Section 2 the latest Quaternary Artostrobium tumidulum Zone, 0 to 0.4 m.y., was recognized. Core 2, Section 3 through the core catcher is assigned to the Pleistocene Axoprunum angelinum Zone, and Core 3, Section 1 through Section 4 is early Pleistocene, Eucyrtidium matuyami Zone, 9 to 1.8 m.y. The core catcher of Core 3 through Core 5, Section 1 is assigned to the late Pliocene Lamprocyrtis heteroporos Zone, 2 to 2.7 m.y. and Core 5, Section 4 through Core 8 , Section 4 is in the Stichocorys peregrina Zone which ranges from the early Pliocene to the late Miocene. Core 8 , Section 4, through Core 9, Section 4, 124-126 cm, contains $S$. delmontensis together with Ommatartus hughesi indicating the late Miocene Ommatartus antepenultimus Zone. 


\section{Mesozoic}

Radiolaria are absent in all of the Cretaceous cores of Hole 310. They were recovered from the cuttings or porcellanite in some of the core-catcher samples of Hole $310 \mathrm{~A}$. They are common to few and moderately well preserved in Cores $8 \mathrm{~A}, 10 \mathrm{~A}, 16 \mathrm{~A}$, and $17 \mathrm{~A}$; common and poor in Cores $11 \mathrm{~A}$ through $13 \mathrm{~A}$; very rare and very poor in Core 14A; and few and poor in Core 18A.

Radiolaria in Cores $8 \mathrm{~A}$ to $13 \mathrm{~A}(231-287 \mathrm{~m})$ are assigned to the Artostrobium urna Zone and in Cores 16A to $18 \mathrm{~A}(306-353 \mathrm{~m})$ to the Dictyomitra somphedia Zone.

\section{SEDIMENTATION RATES}

Continuous coring at Site 310 and relatively good recovery of the upper 100 meters of the section gives fairly close control of the time of deposition down into the Upper Cretaceous (Figure 6). The accumulation rate for the Pliocene and upper Miocene is about $6 \mathrm{~m} / \mathrm{m} . \mathrm{y}$. An unconformity separates the middle Miocene and the early Oligocene. Other unconformities occur separating early Oligocene and middle Eocene; middle Eocene to early Eocene; and early Eocene and middle Maestrichtian. The average rate of accumulation for the Upper Cretaceous (Maestrichtian through Cenomanian) is about $11 \mathrm{~m} / \mathrm{m} . \mathrm{y}$.

The moderate accumulation rates of 8 to $16 \mathrm{~m} / \mathrm{m} . \mathrm{y}$. calculated for the section are reasonable values for a pelagic sequence. The Cretaceous values are probably a minimum because no correction has been applied for compaction and diagenesis. The very low rate in the lower Oligocene to lower Eocene, an order of magnitude lower than is suggested by the pelagic nature of the sediments, indicates that a considerable amount of section is missing as a result of dissolution or erosion.

From the average accumulation rate for the Cretaceous, an estimated age for the basement, using a value for basement depth of 425 to 450 meters, is 103 to 106 m.y. (lower Albian). This age agrees quite well with the estimates of Larson and Chase (1972) and Lancelot et al. (in preparation) for this portion of the western North Pacific.

The accumulation rates from Hess Rise are similar to those found on Shatsky Rise (Site 305). The Pleistocene through upper Miocene average rate from Shatsky Rise is $8 \mathrm{~m} / \mathrm{m}$.y. versus $6 \mathrm{~m} / \mathrm{m}$.y. for Hess Rise; Maestrichtian to Cenomanian average rates are $11 \mathrm{~m} / \mathrm{m} . \mathrm{y}$. at both sites. The unconformity between middle Miocene and Oligocene on Hess Rise corresponds rather closely with the early Miocene to upper Oligocene unconformity cored on Shatsky Rise (Sites 47 and 305). The lower Eocene to Upper Cretaceous (Maestrichtian) unconformity found on Hess Rise, however, does not have a counterpart at our Shatsky Rise sites.

\section{SUMMARY AND CONCLUSIONS}

The section cored at Hess Rise is summarized in Figure 7. It consists of 79 meters of soft, highly fossiliferous Neogene oozes, overlying about 16 meters of zeolitic calcareous pelagic clays of Paleogene age and a Cretaceous section of at least 257 meters of calcareous oozes and chalks that become increasingly cherty with depth.

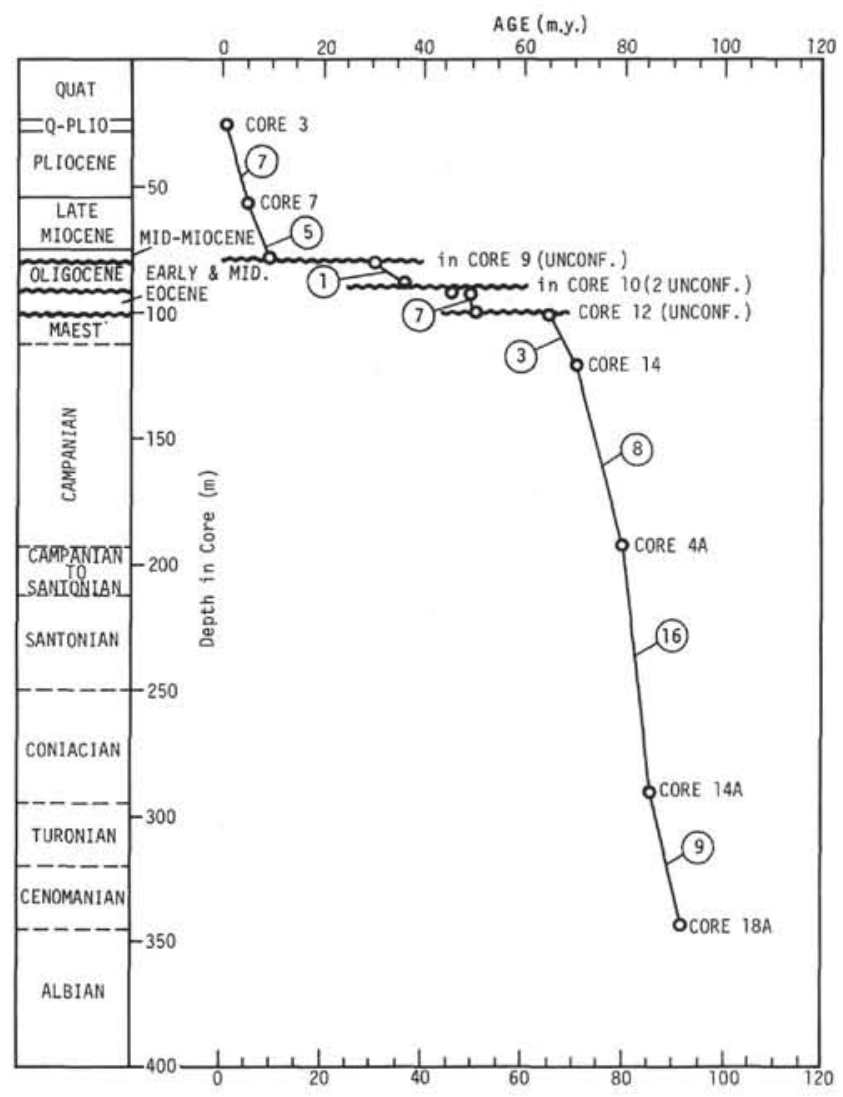

Figure 6. Accumulation rate curve calculated for Site 310. Circled numbers give accumulation rate in $\mathrm{m} / \mathrm{my}$ for each segment.

The Neogene cores collected will probably prove to have the most value to biostratigraphers. The Quaternary is unusually thick for the mid-ocean of temperate latitude, and it contains several cycles of sediment type reflecting oceanographic events in the Central North Pacific. Foraminifers, radiolarians, nannofossils, diatoms, and silicoflagellates are all present and except for the foraminifers, their preservation is good. In the Pliocene and Miocene the abundance and state of preservation of some of these groups drop off somewhat, but the main restriction to the use of the Neogene fossils is liable to be the disturbance during coring whereby the sediment was injected in a swirling and diapiric fashion into the core barrel. It appears that the Miocene to Pliocene contact is blurred in such a manner, for example.

The Paleogene was a time of disruption in sedimentation, now evidenced by missing fossil zones and by zeolitic sediments. The lack of radiolarians and strong evidence of solution of foraminifers and coccoliths indicate that corrosion of the planktonic component of the sediment was as important or probably more important than erosion. As is so common in the Western Pacific, deposits of early Miocene age are missing; in fact at Site 310 the unconformity within Core 9 is of upper Miocene sediments on lower Oligocene ones.

At least six other unconformities, or perhaps greatly compressed sections, exist in the upper part of the section. There was no recovery of the late Eocene or of the 


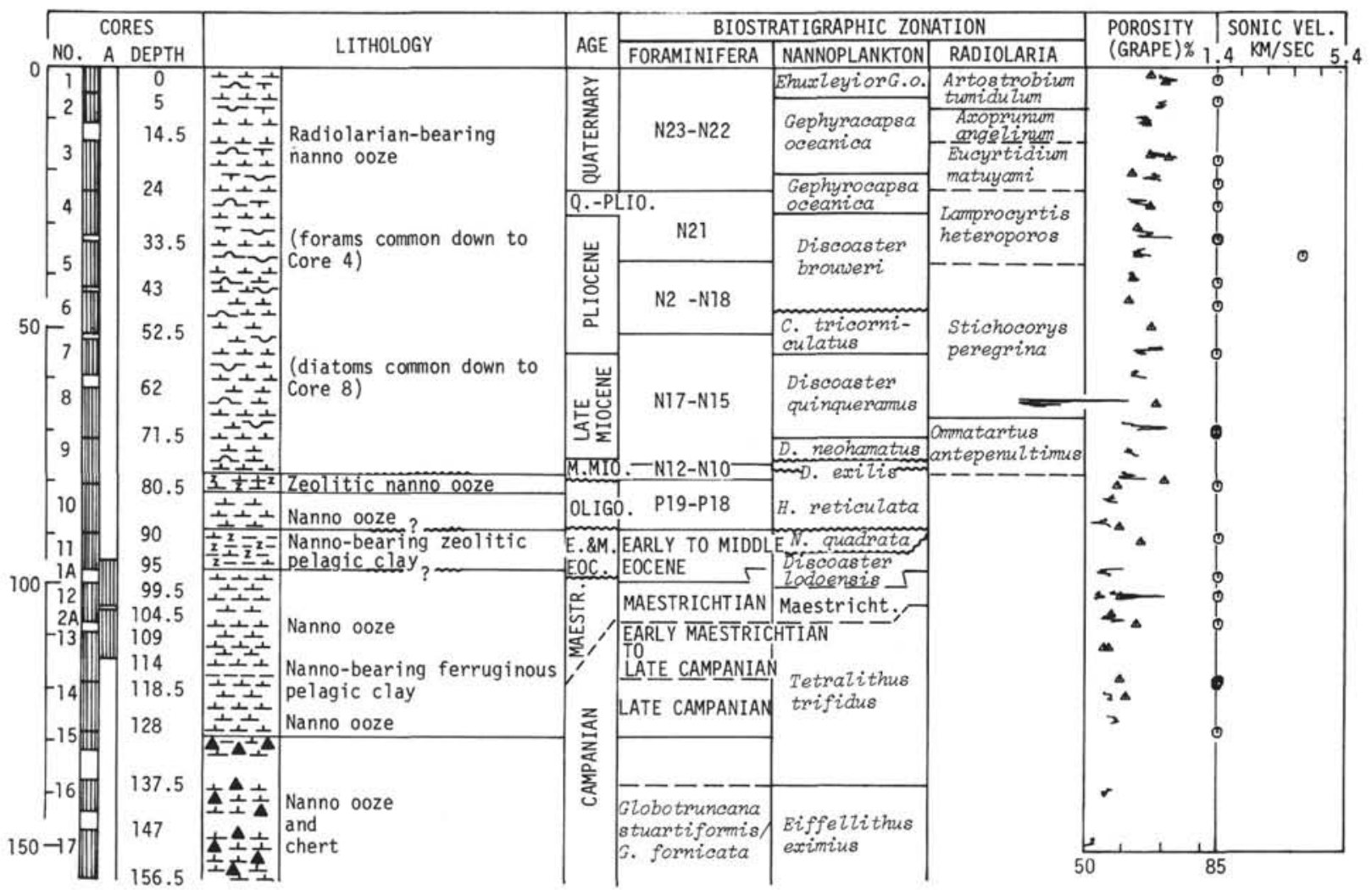

Figure 7. Summary of coring, lithology, biostratigraphy, and physical properties at Site 310.

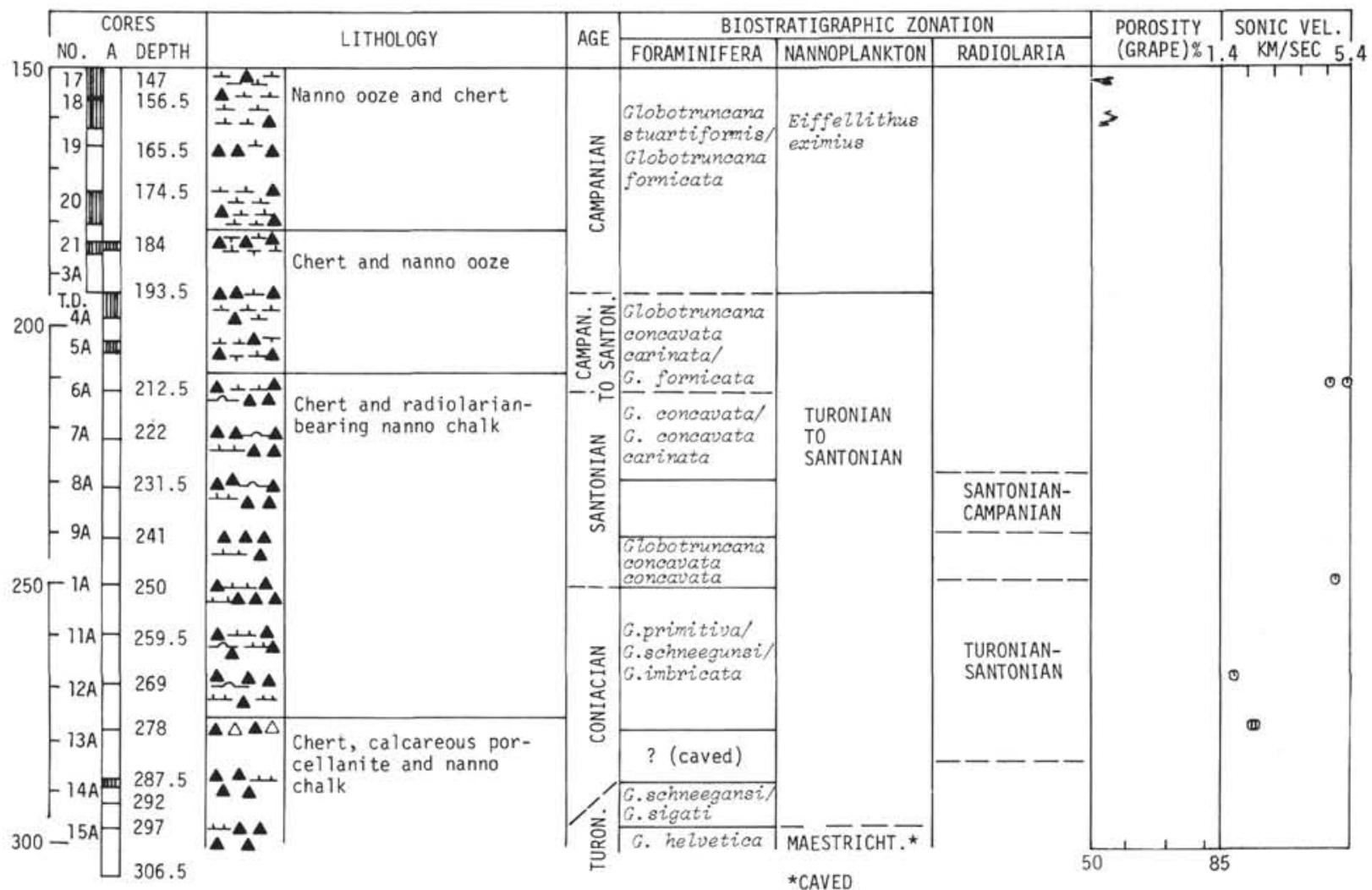

Figure 7. (Continued). 


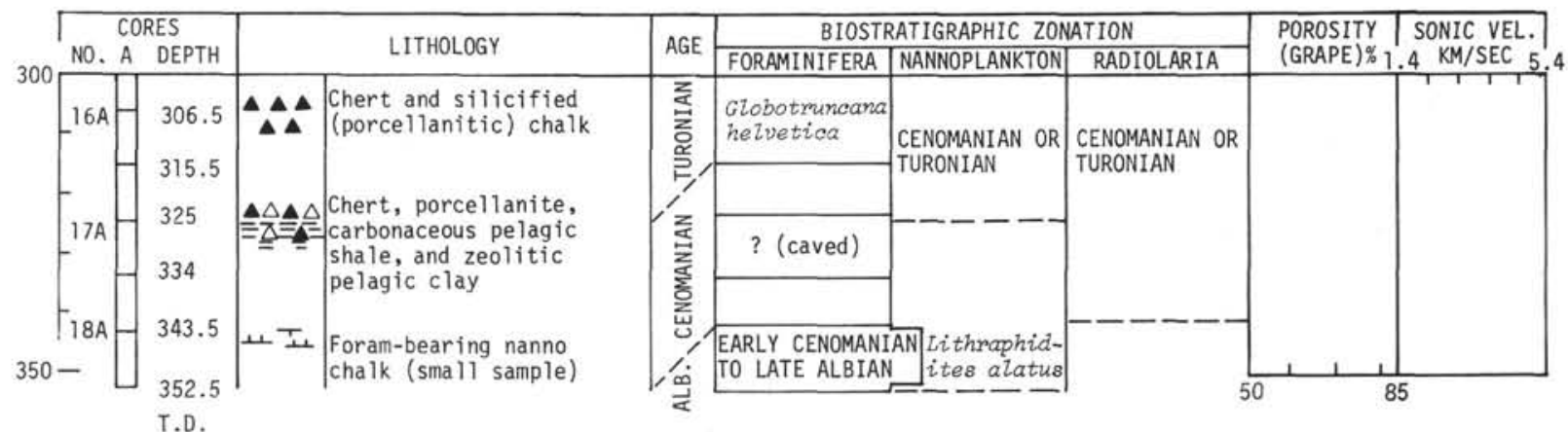

Figure 7. (Continued).

Paleocene, but those gaps are between cores rather than within the cores. Their exact depth and extent therefore are open to speculation, as it is evident that the intervals recovered in the cores are not necessarily the same as the section in situ. For example, the Mesozoic-Cenozoic contact fell between Cores 11 and 12 of Hole 310, and the placement of Core $1 \mathrm{~A}$ of the redrilled hole $(310 \mathrm{~A}$ was drilled within $15 \mathrm{~m}$ of 310 ) was an attempt to recover the contact. The top of Core 1A was Maestrichtian, at the level that was Eocene in Core 11. Apparently Core 11 had filled early with sediment pressed up into it, and the actual contact is somewhere between the 90meter top of Core 11 and the 95-meter top of Core 1A. Unfortunately, this circumstance may not be unique, as there may be other places in the soft sediments above 170 meters in which excess sediment was stuffed early into the core barrel. Then the barrel would be full before the bit reached the lower part of a cored interval. The lower interval would thereby be unsampled.

In the Cretaceous section recovery was poor, especially as the proportion of chert increased below 170 meters. The diversity of fossils as well as their abundance and preservation are also poor. A method of recovering soft sediment in sections with chert or porcellanite layers would be of great value to this project. Close zonation of the Upper Cretaceous section is not possible, but all the stages appear to be represented.

The nature and age of basement of Hess Rise remain unknown. Almost certainly the basement is basalt, as it is where cored on Magellan Rise and Ontong-Java Plateau, and as the combination of refraction and gravity surveys suggest elsewhere. But the specific type of basalt at Site 310 is not known.

If the average rate of accumulation of sediment of about $11 \mathrm{~m} / \mathrm{m} . \mathrm{y}$. for the Upper Cretaceous is extrapolated to the probable depth of basement of 425 to 450 meters, the age of oldest sediment would be about 103 to 106 m.y., or early Albian. If the somewhat slower rate shown by the five lowest cores of about $6 \mathrm{~m} / \mathrm{m}$.y. is used, the age of oldest sediment would be about 110 to 114 m.y., late Barremian or early Aptian.

These estimates of age are based on a number of assumptions, of which the most critical is the one that pelagic chalk, ooze, and chert are the dominant sediments between the total depth of the hole and basement. At Site 167 on Magellan Rise and at Site 289 on Ontong-Java Plateau pelagic sediments continue down to basement. By analogy with those plateaus the assump- tion of pelagic sedimentation at Hess Rise, on which we base our projections of sonic velocities and rates of accumulation, appears reasonable. If this projected basement age is approximately correct, Hess Rise is not an ancient outlier surrounded by generally younger oceanic crust of more average depth. Instead, the early Albian age projected to basement is close to that predicted by plate tectonic models for this area (Larson and Chase, 1972; Lancelot et al., in preparation).

The possibility of one or more hiatuses in the undrilled section is more of a problem. Site 289 had a hiatus of 30 m.y. within 30 meters of basement, and certainly on reflection profiles near our Site 310 the thickness of the lowest acoustostratigraphic unit above basement varies markedly. The changes in its thickness appear to be controlled largely by topography, and layering within the unit is too indistinct on the records to decide whether the thicker sections in the depressions resulted from downslope sedimentation there filling them earlier than adjacent high areas, or from even sedimentation over all but later erosion of the high areas and preservation of sediment in the depressions. Unfortunately, hiatuses have been all too common at plateau sites drilled to date.

All in all, it appears most likely that the basement under this site is late Early Cretaceous in age, but to narrow those limits to a particular stage will require additional information. After leaving Site 310 we traveled south, away from the storms and toward the next scheduled site, across Hess Rise to its southern end near Mellish Bank. Nowhere did we find a site suitable for reaching basement within the 2 to 2.5 days we could afford to spend on a second location. So the recovery and description of basement and the earliest sediments of Hess Rise, like Shatsky Rise, await later expeditions.

\section{REFERENCES}

Chase, T. E., Menard, H. W., and Mammerickx, J., 1971 Topography of the North Pacific: Institute of Marine Resources, University of California, San Diego.

Davies, T. A., Clague, D. A., and Wilde, P., 1971. Preliminary report on Leg VII of Aries expedition: Scripps Institution of Oceanography. Ref. 71-27, 21 p.

Lancelot, Y., Carpenter, G., and Ewing, J. I., in preparation. Sedimentary and tectonic evolution of the Pacific plate since the early Cretaceous.

Larson, R. L. and Chase, C. G., 1972. Late Mesozoic Evolution of the Western Pacific: Geol. Soc. Am. Bull., v. 83, p. 3627-3644. 


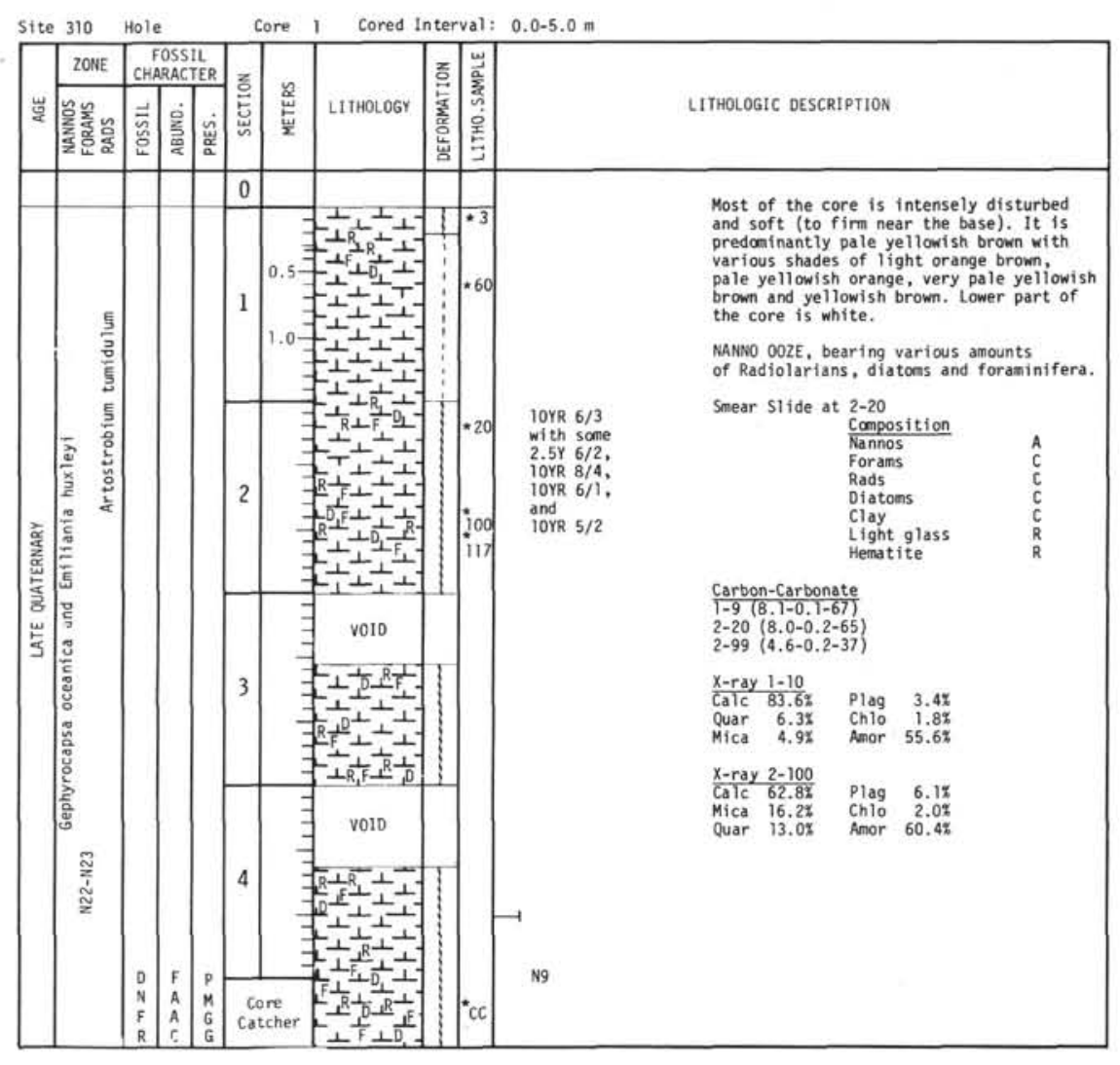

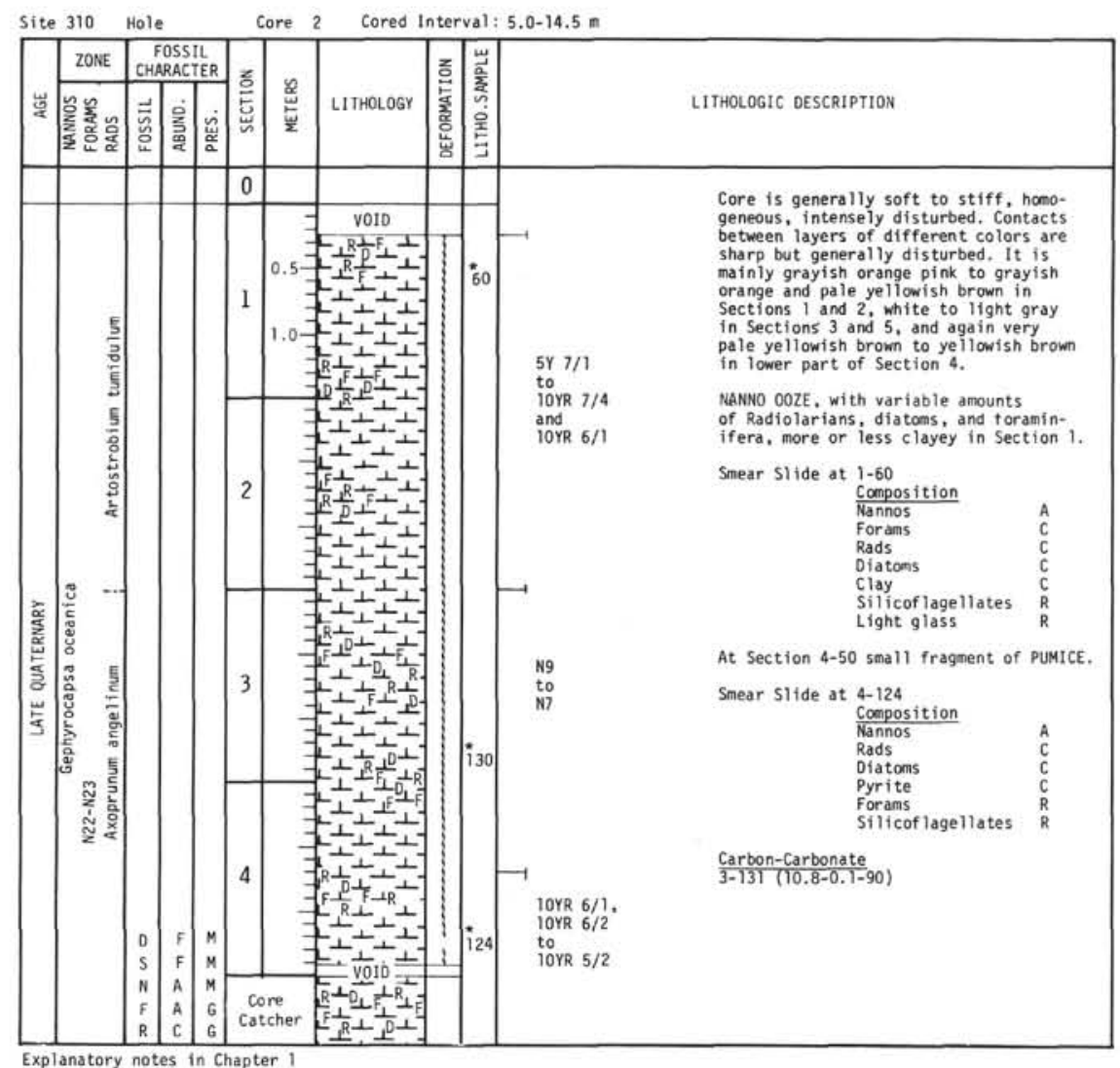




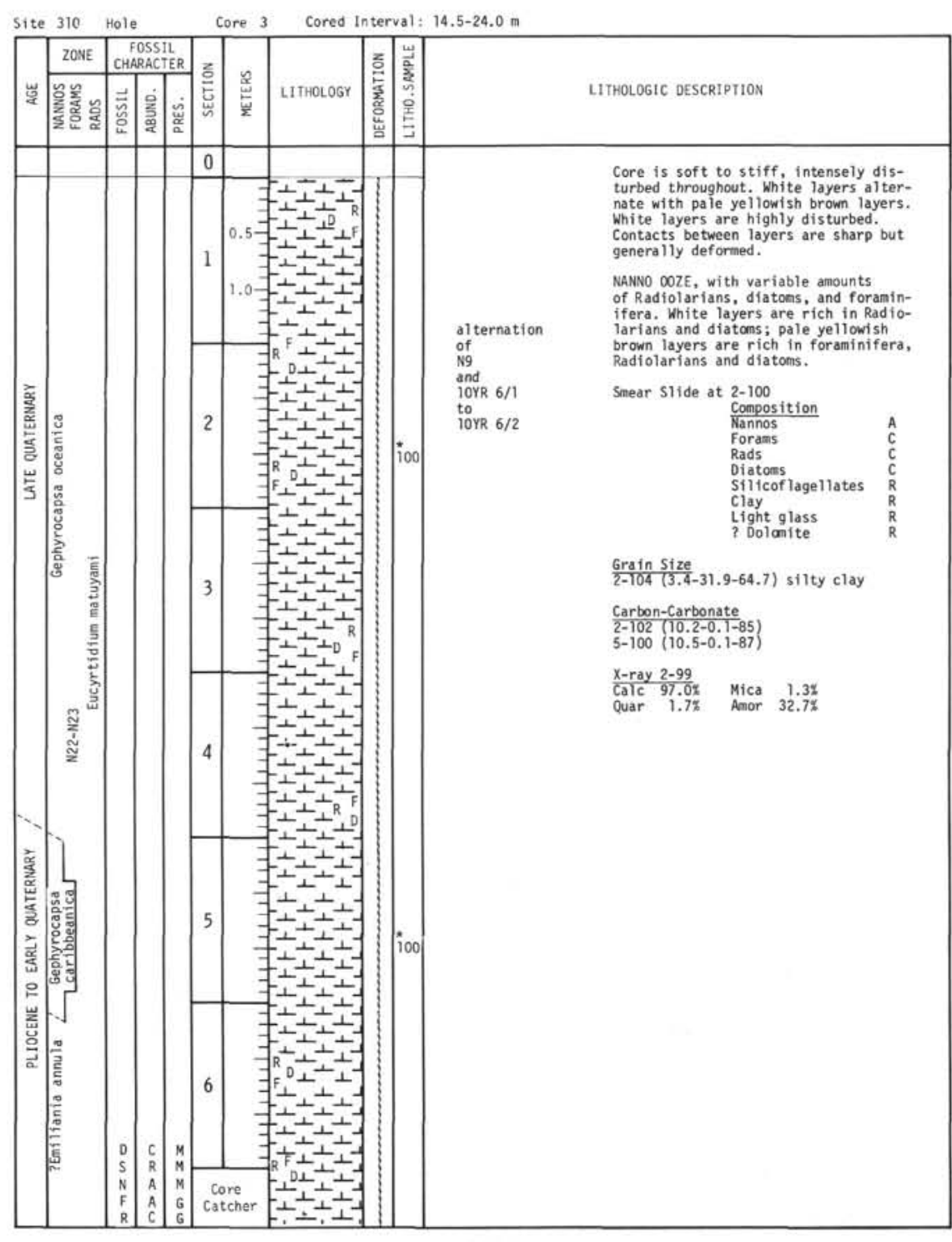

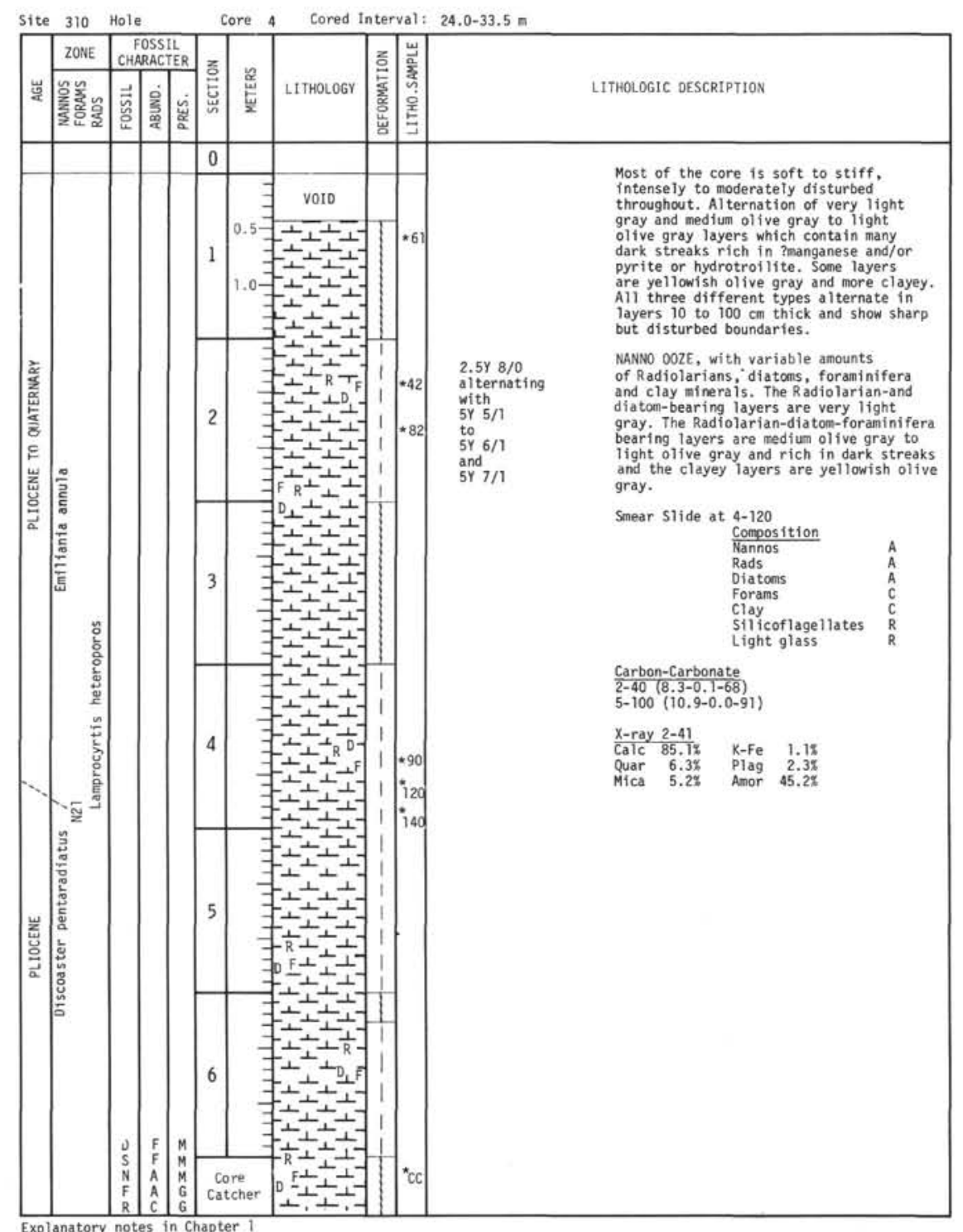



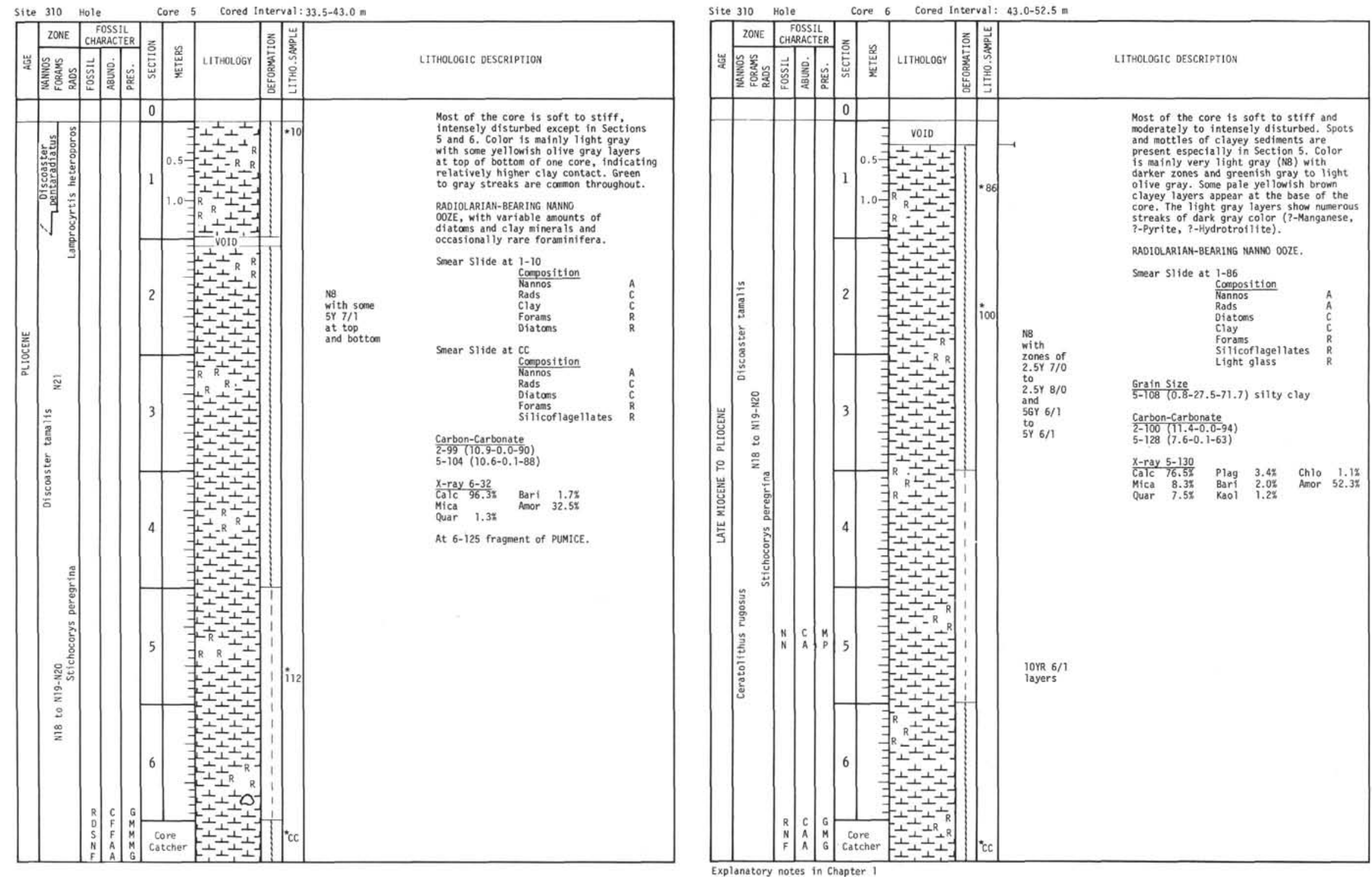


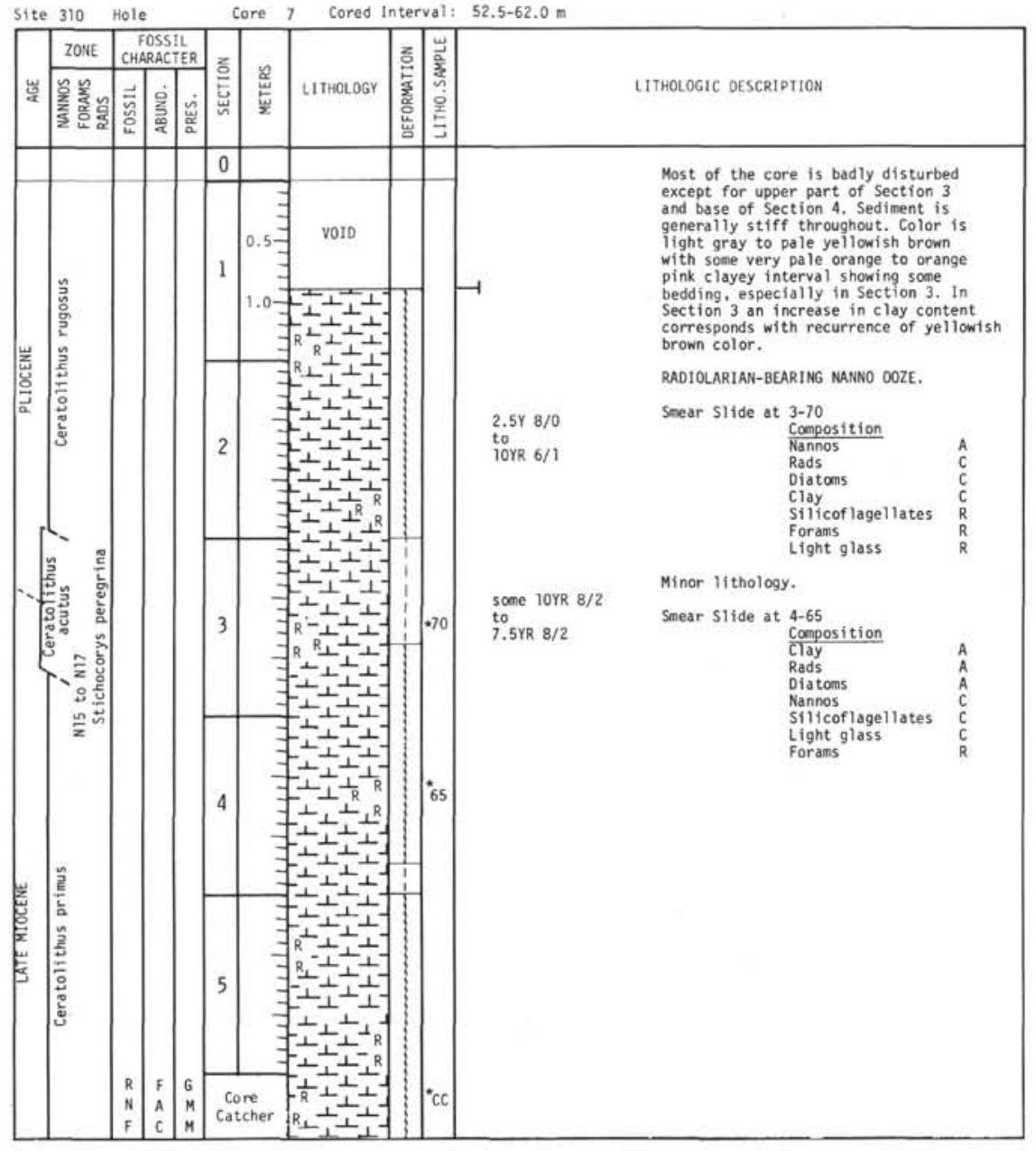




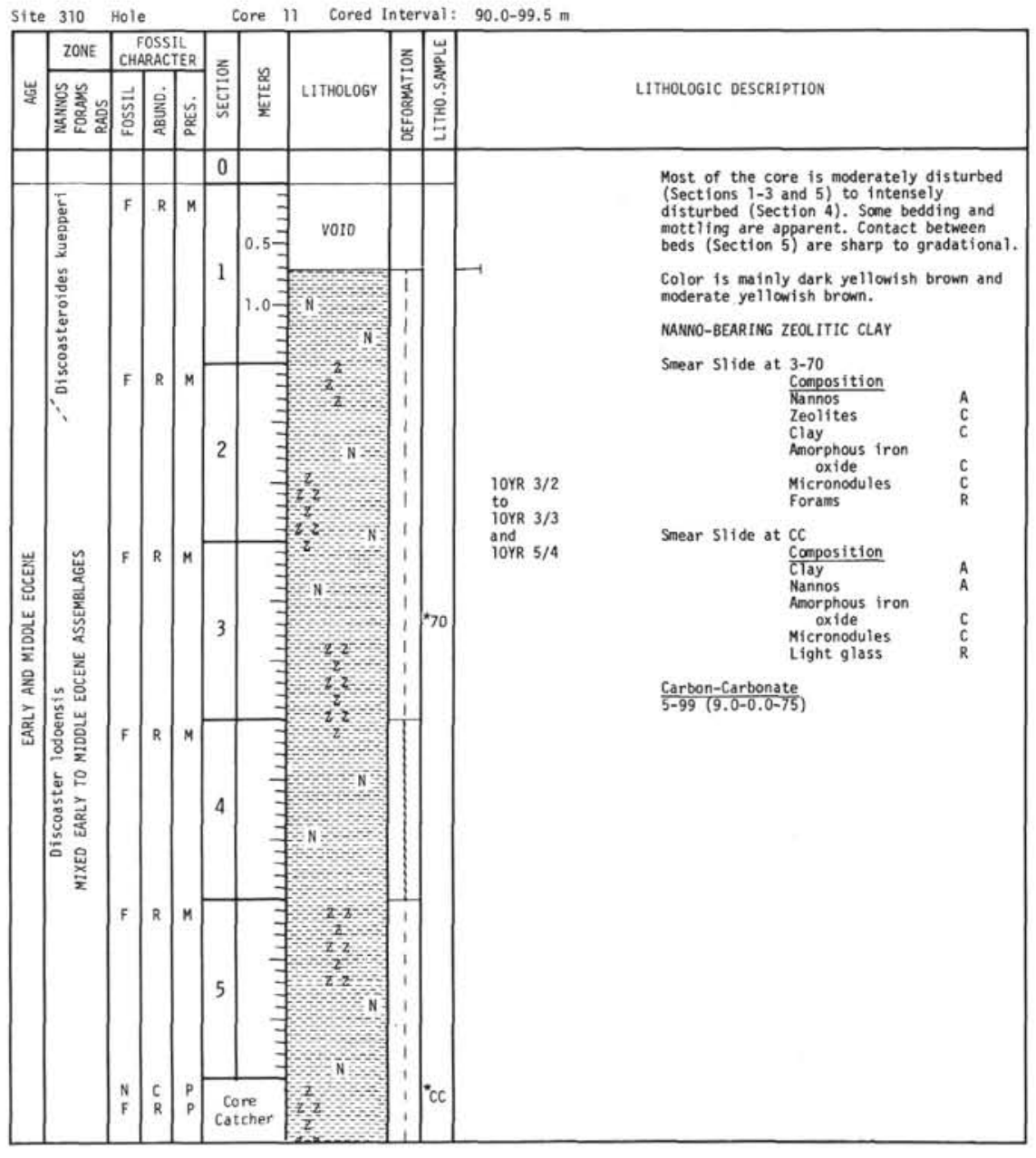

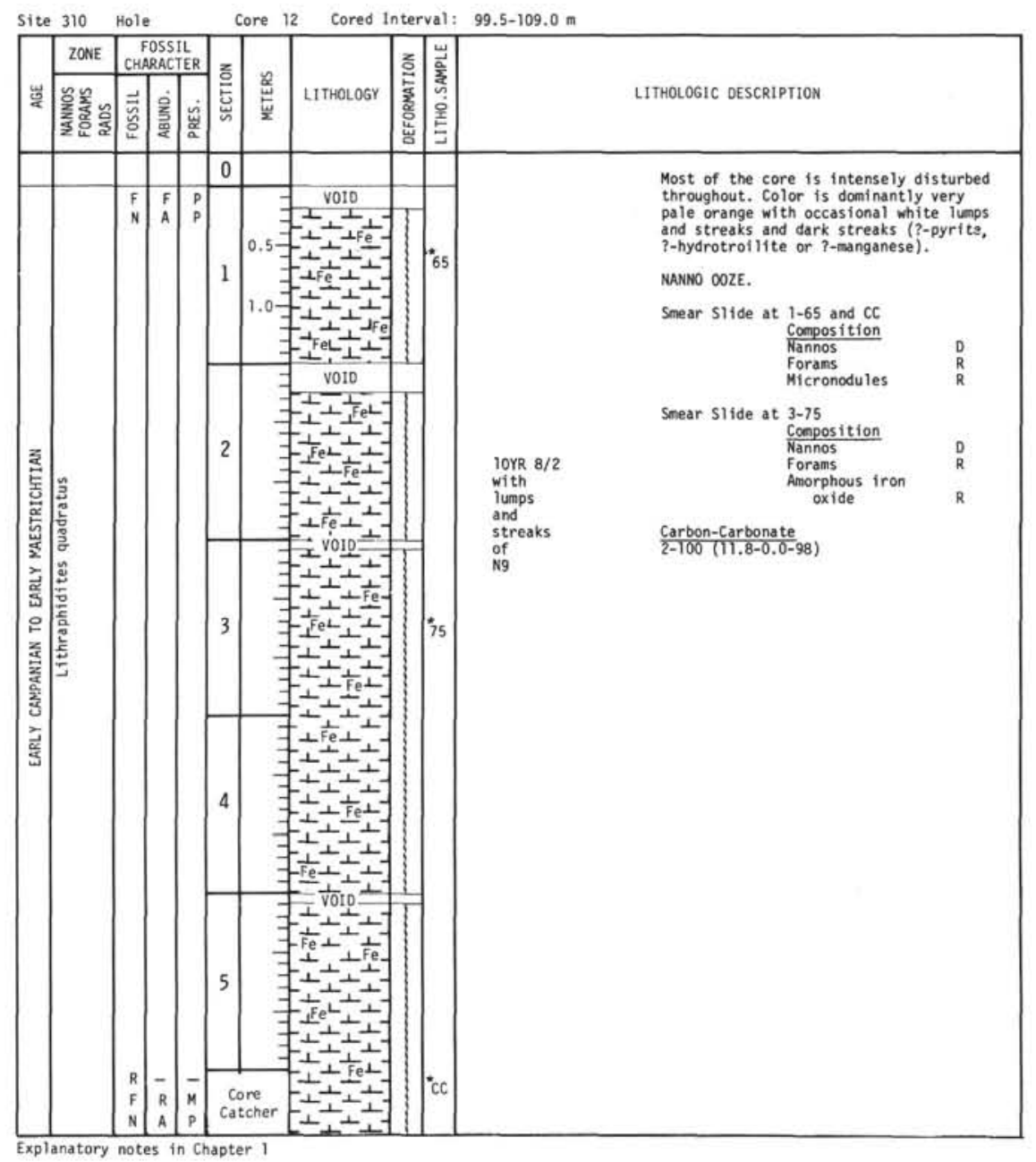




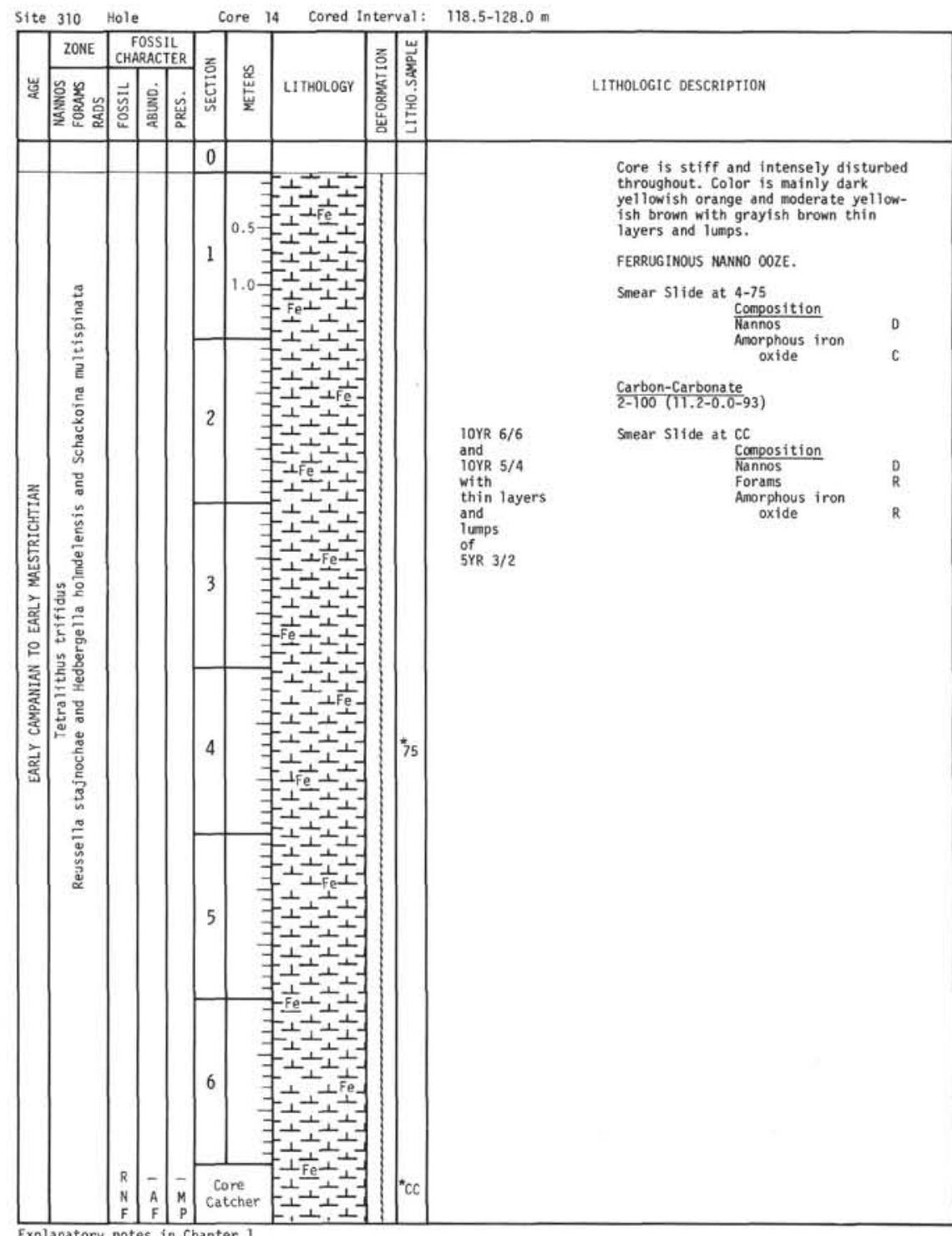




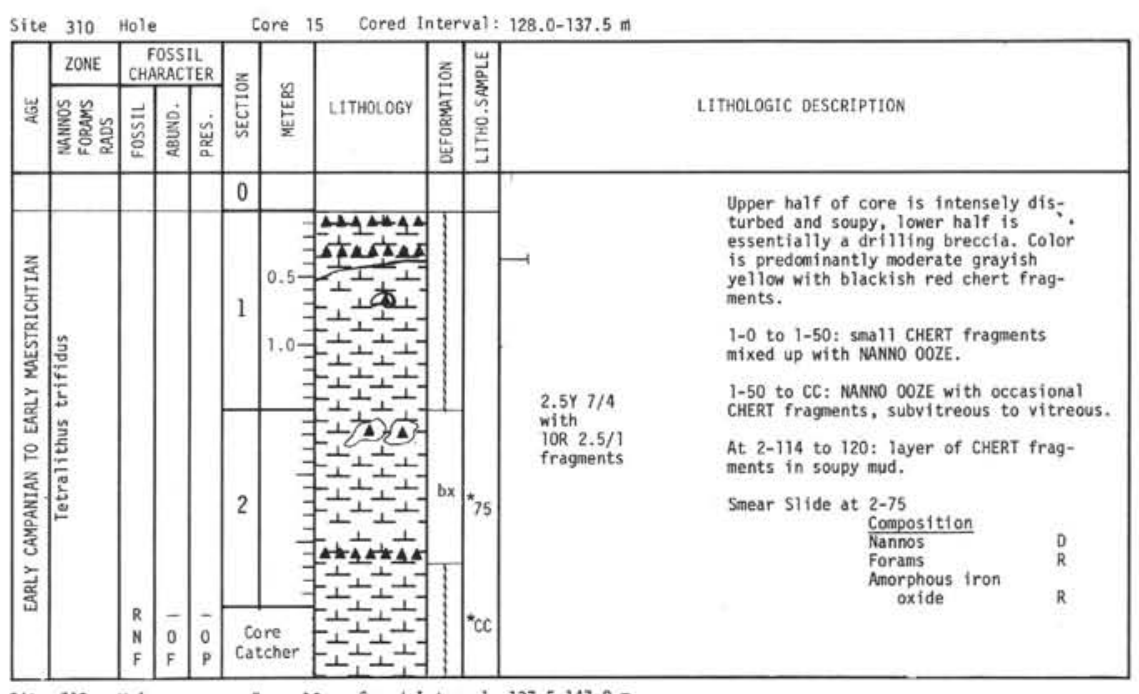

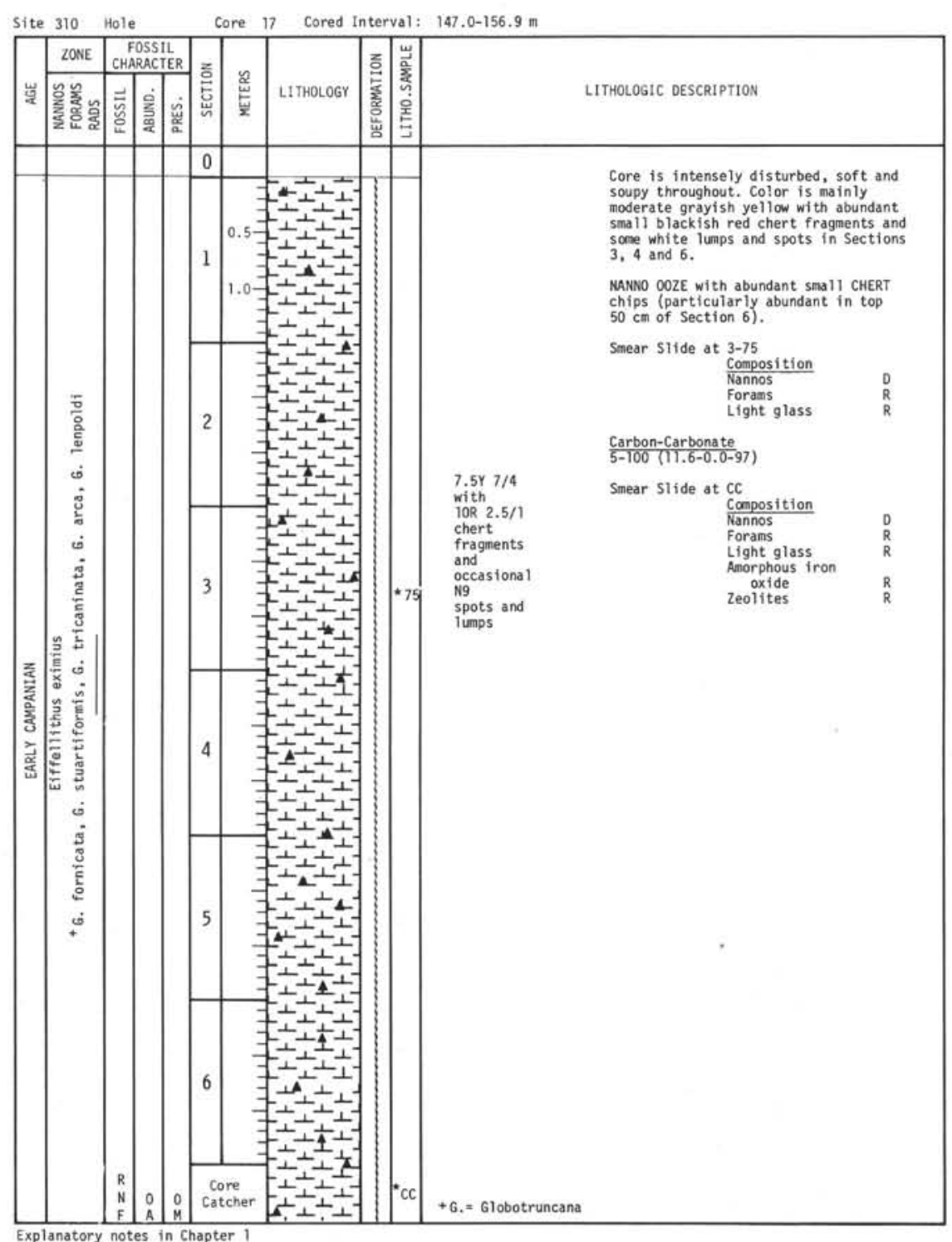

\begin{tabular}{|l|l|l|l|l|l|l|}
\hline Site 310 & Hole \\
\hline
\end{tabular}



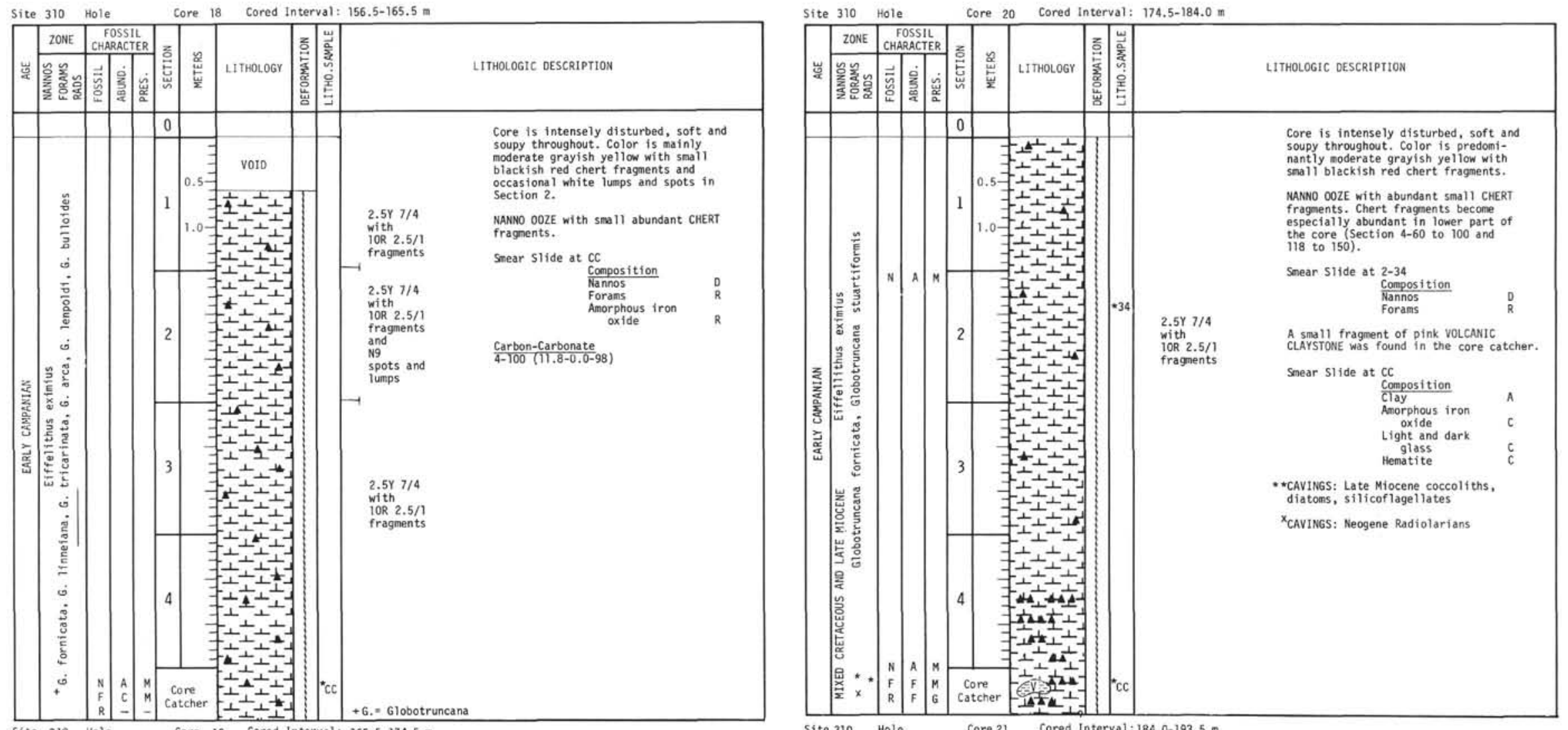

\begin{tabular}{|l|l|l|l|l|l|l|l|}
\hline \\
\hline
\end{tabular}

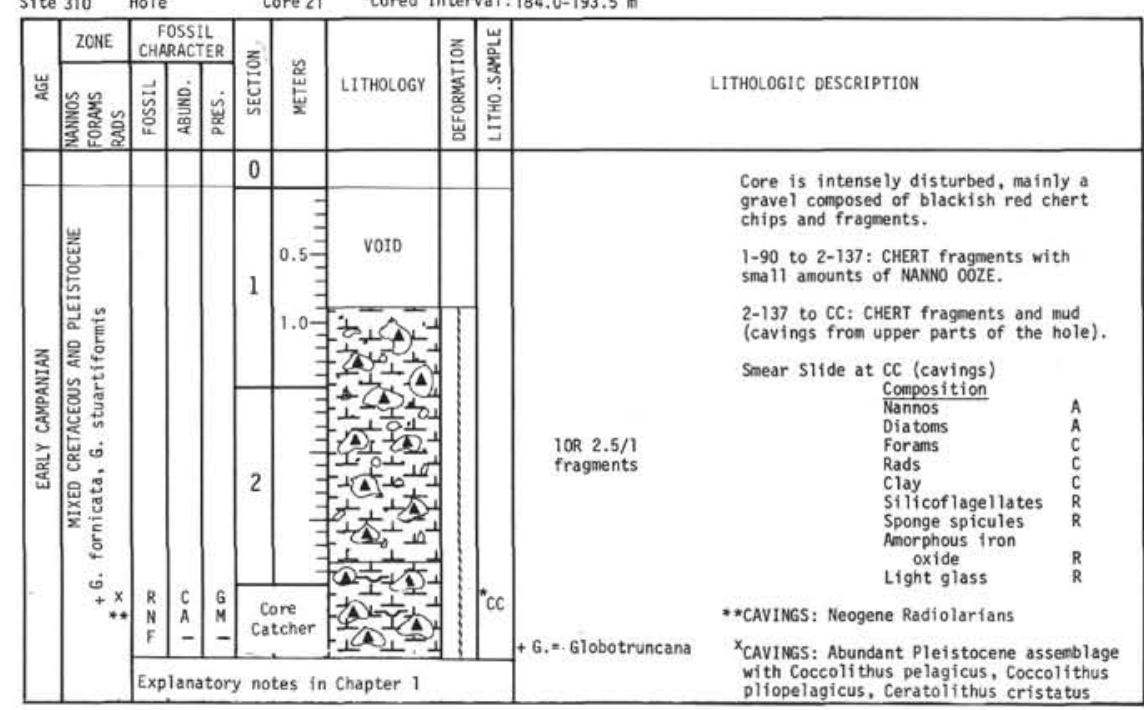



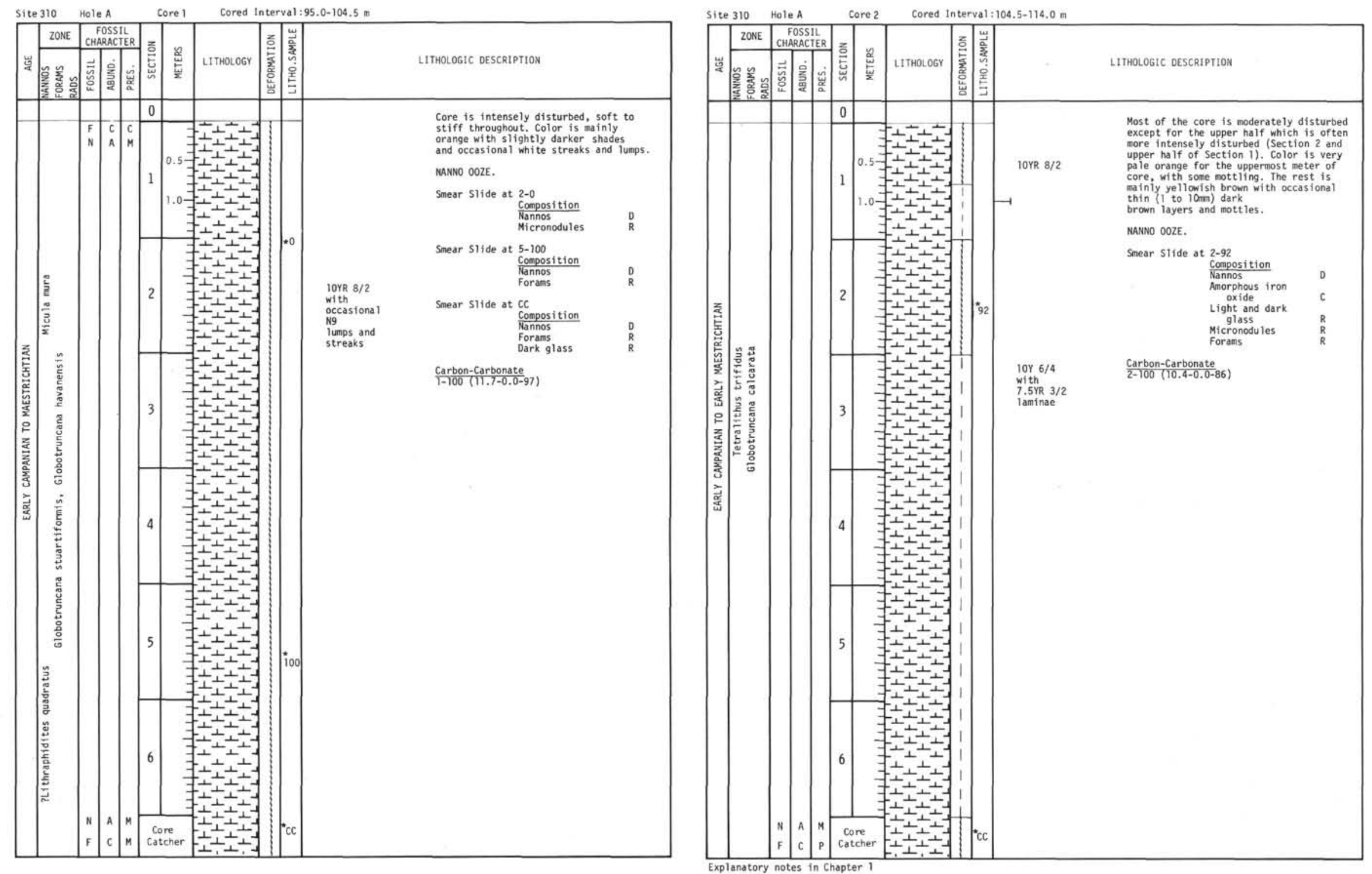


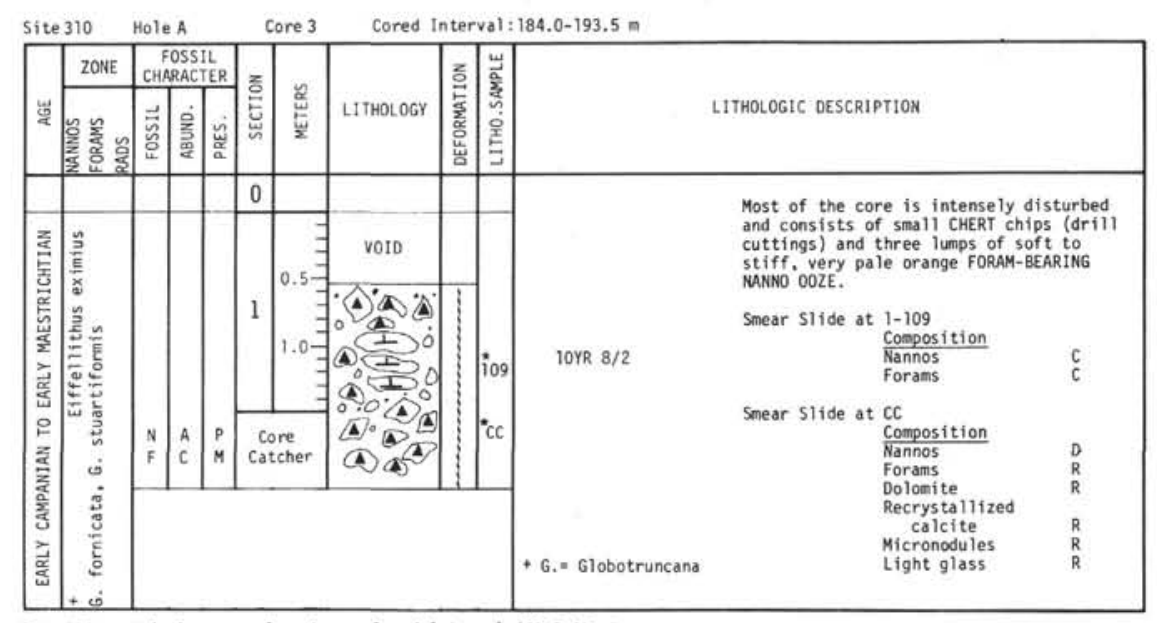

Site 310 Hole A Core 5 Cored Interval: 203.0-212.5 m

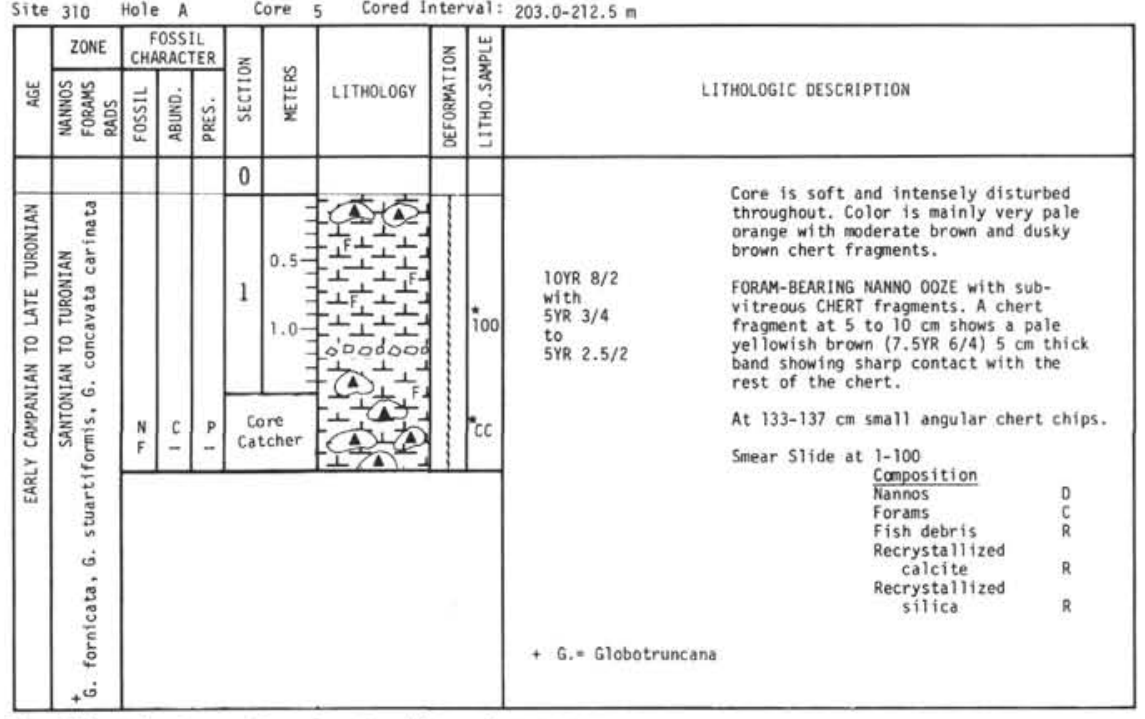

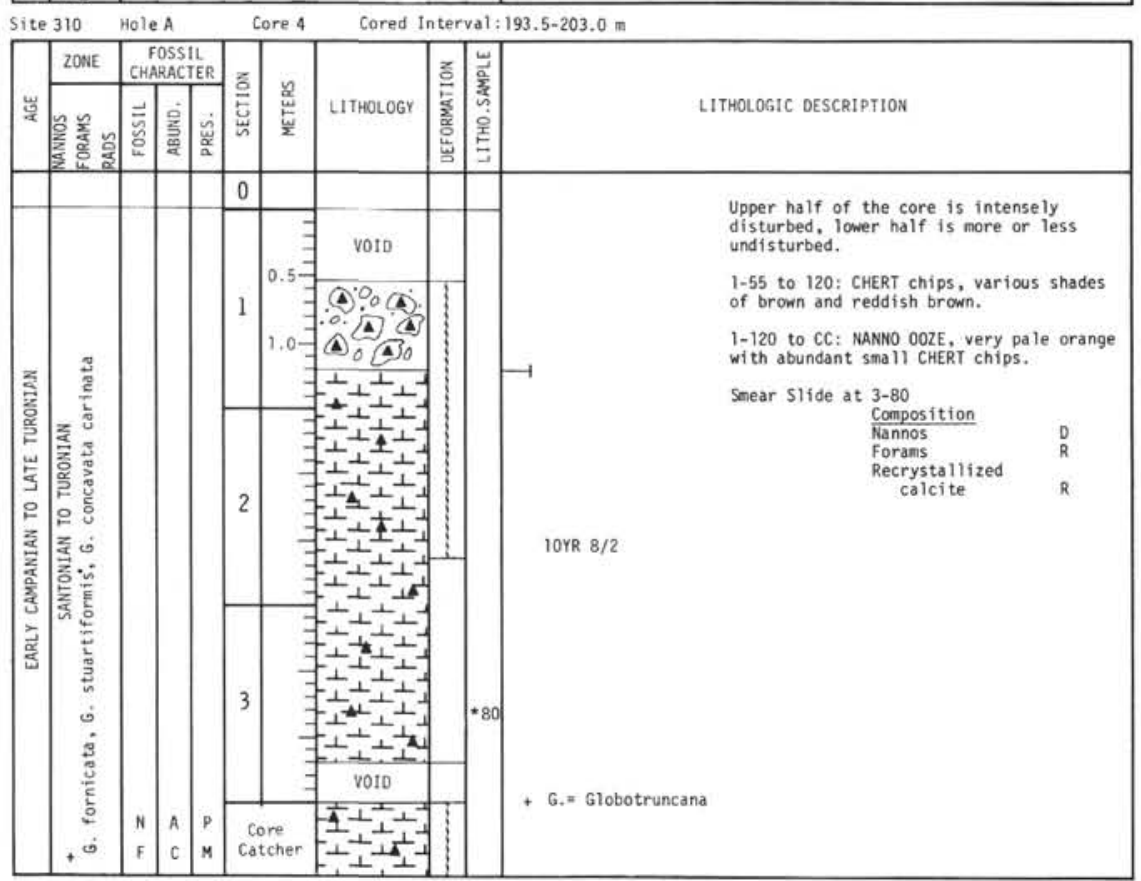

\begin{tabular}{|c|c|c|c|c|c|c|c|}
\hline \\
\hline
\end{tabular}

Explanatory notes in Chapter 1 


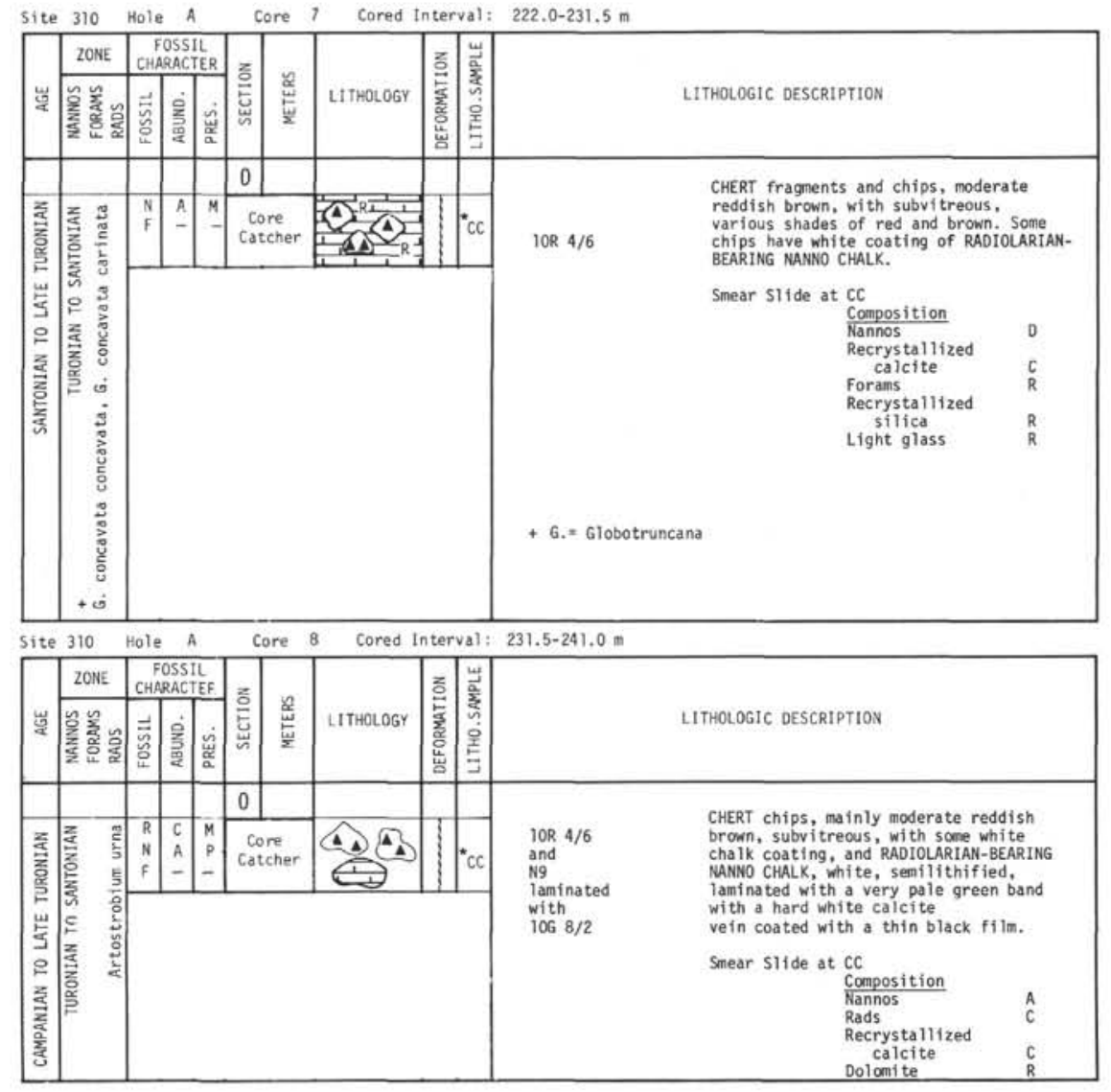

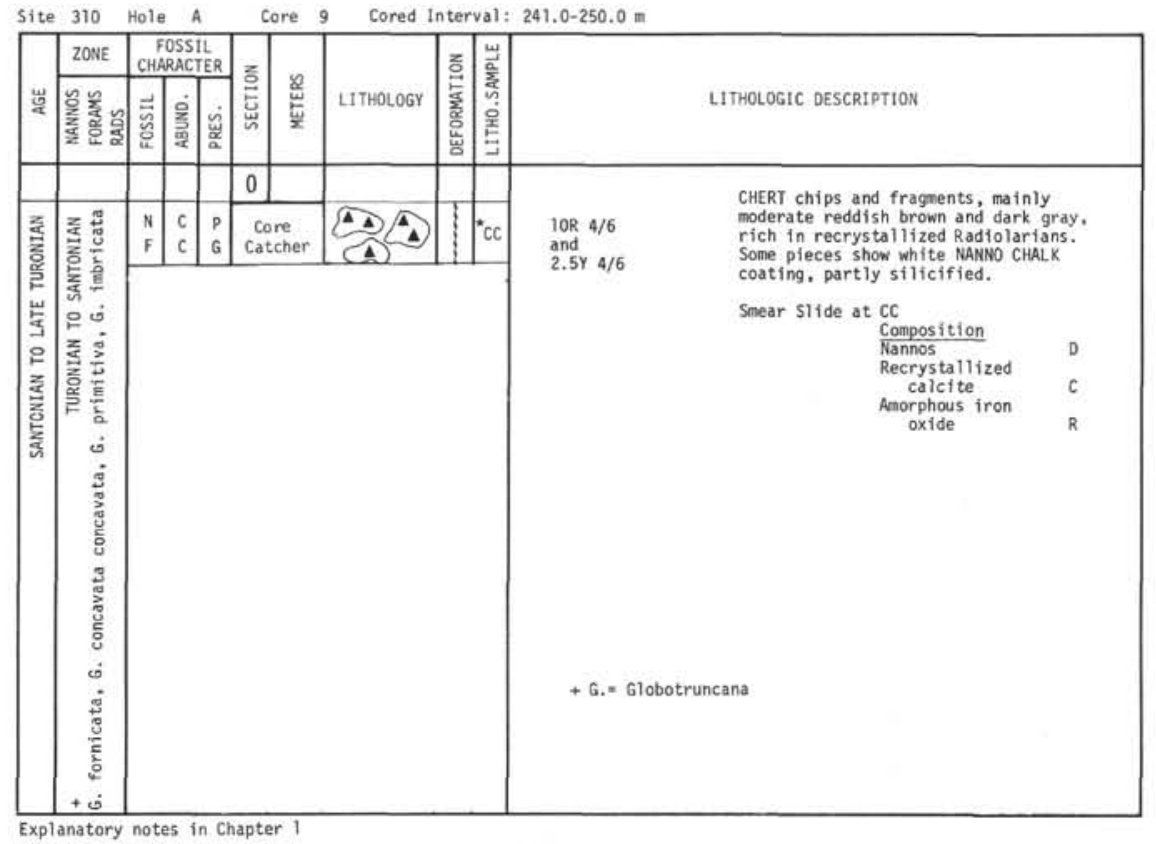




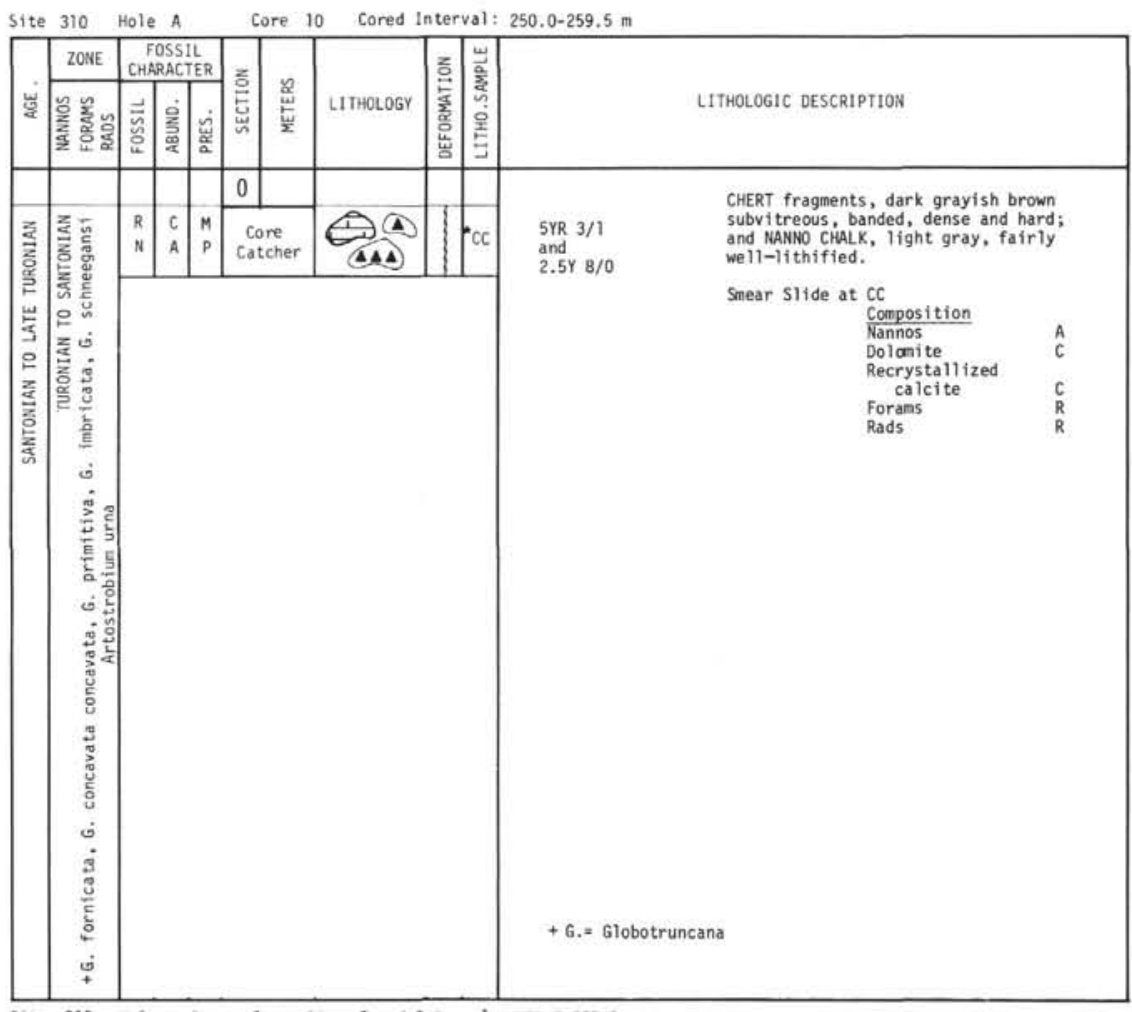

Site 310 Hole A Core 12 Cored Interval: $269.0-278.0 \mathrm{~m}$

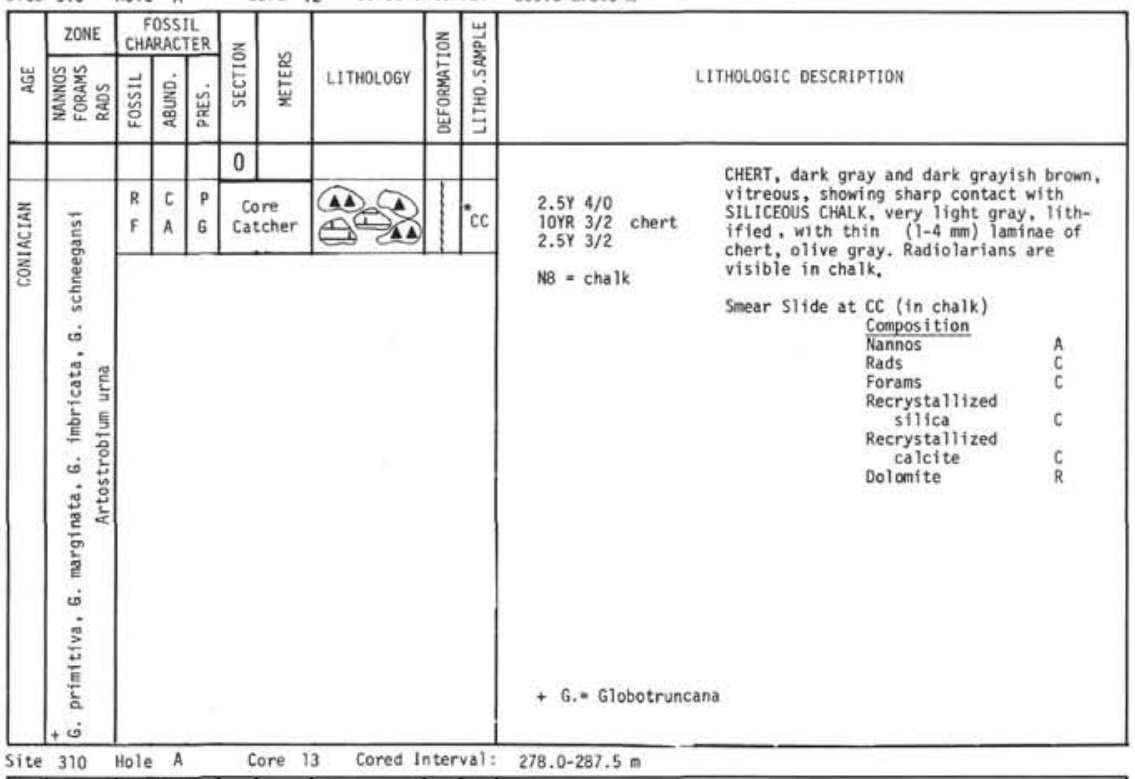

ite 310 Hole A Core 11 Cored Interval: $259.5-269.0$

\begin{tabular}{|l|l|l|l|l|l|l|l|l|l|}
\hline Site & 310 & Hole & A \\
\hline
\end{tabular}

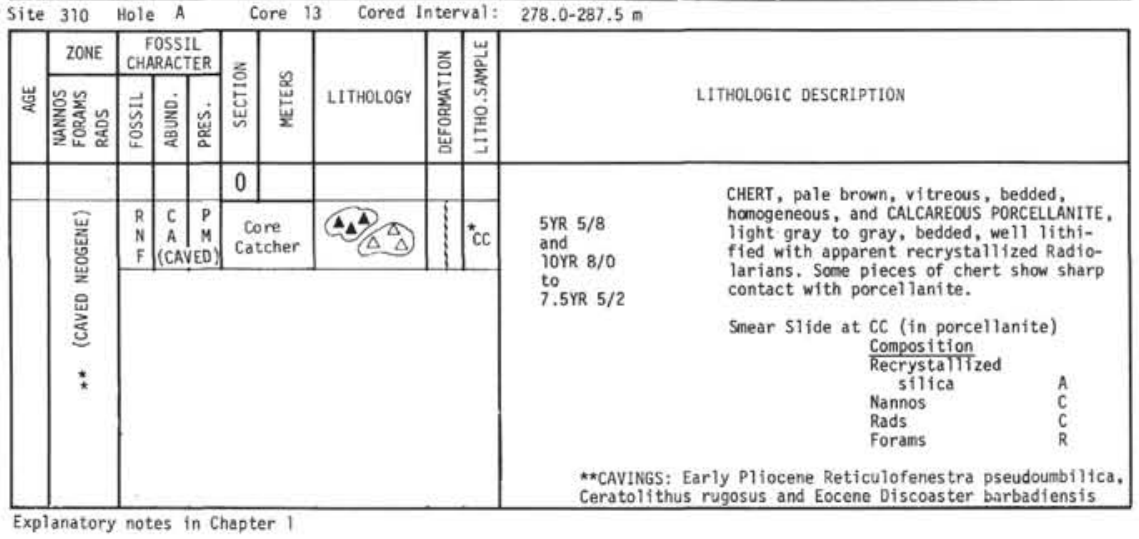



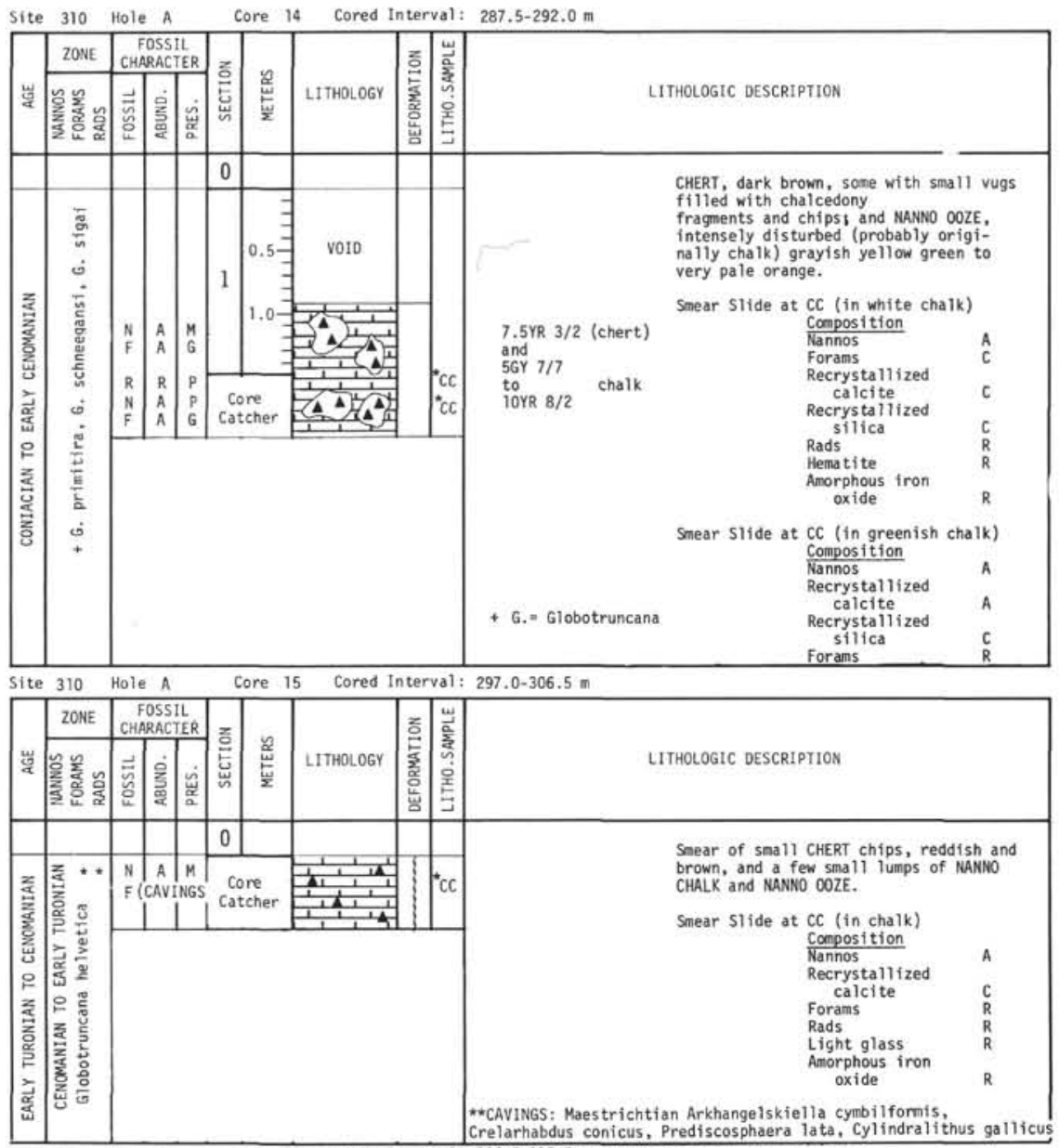

\begin{tabular}{|l|l|l|l|l|l|l|l|l|l|}
\hline Site 310 & \multicolumn{3}{c|}{ Hole A } & Core 16 & Cored Interval: $306.5-315.5 \mathrm{~m}$ \\
\hline
\end{tabular}

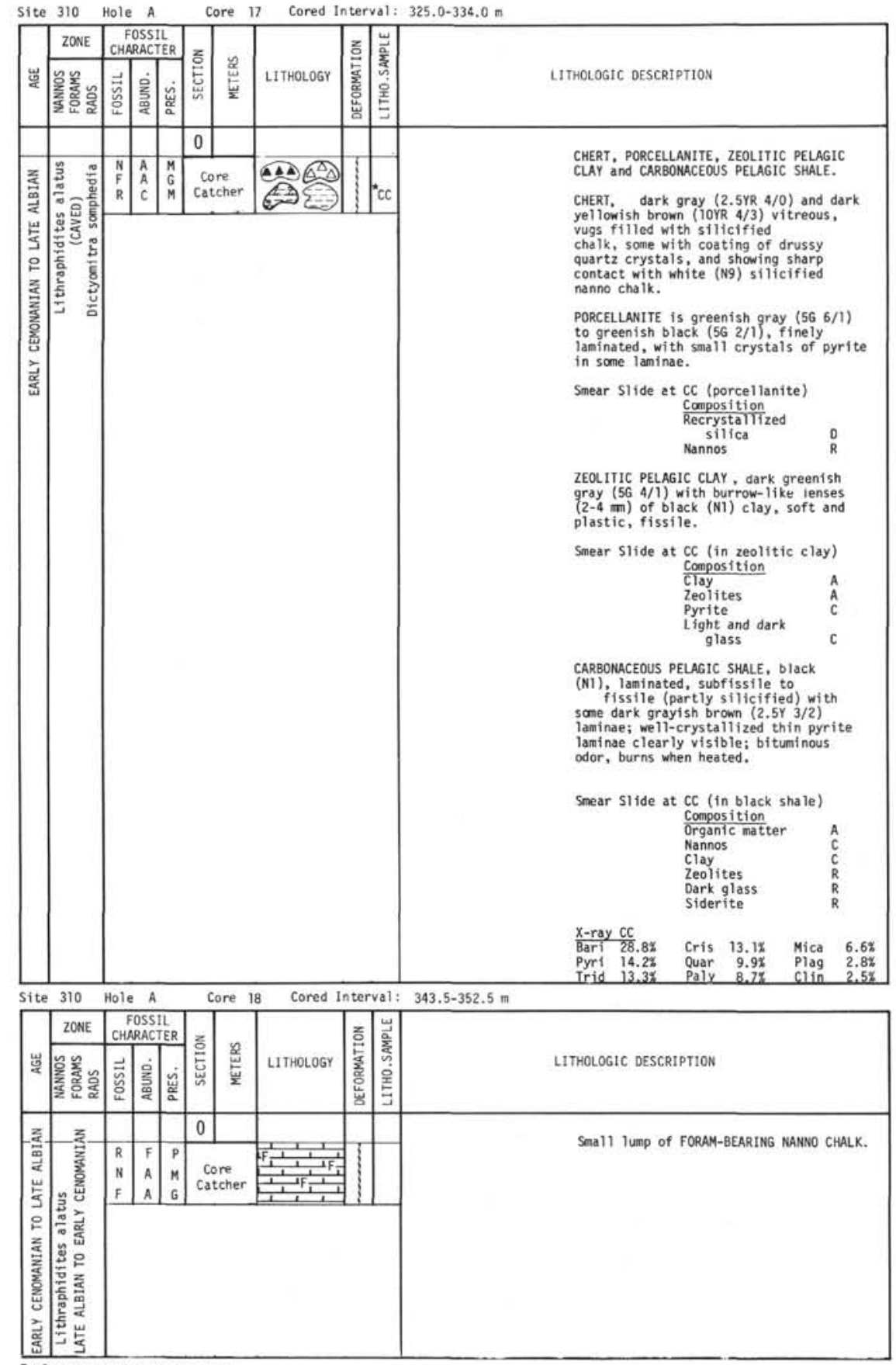


- Syringe porosity, $\%$ COMPRESSIONAL SOUND VELOCITY

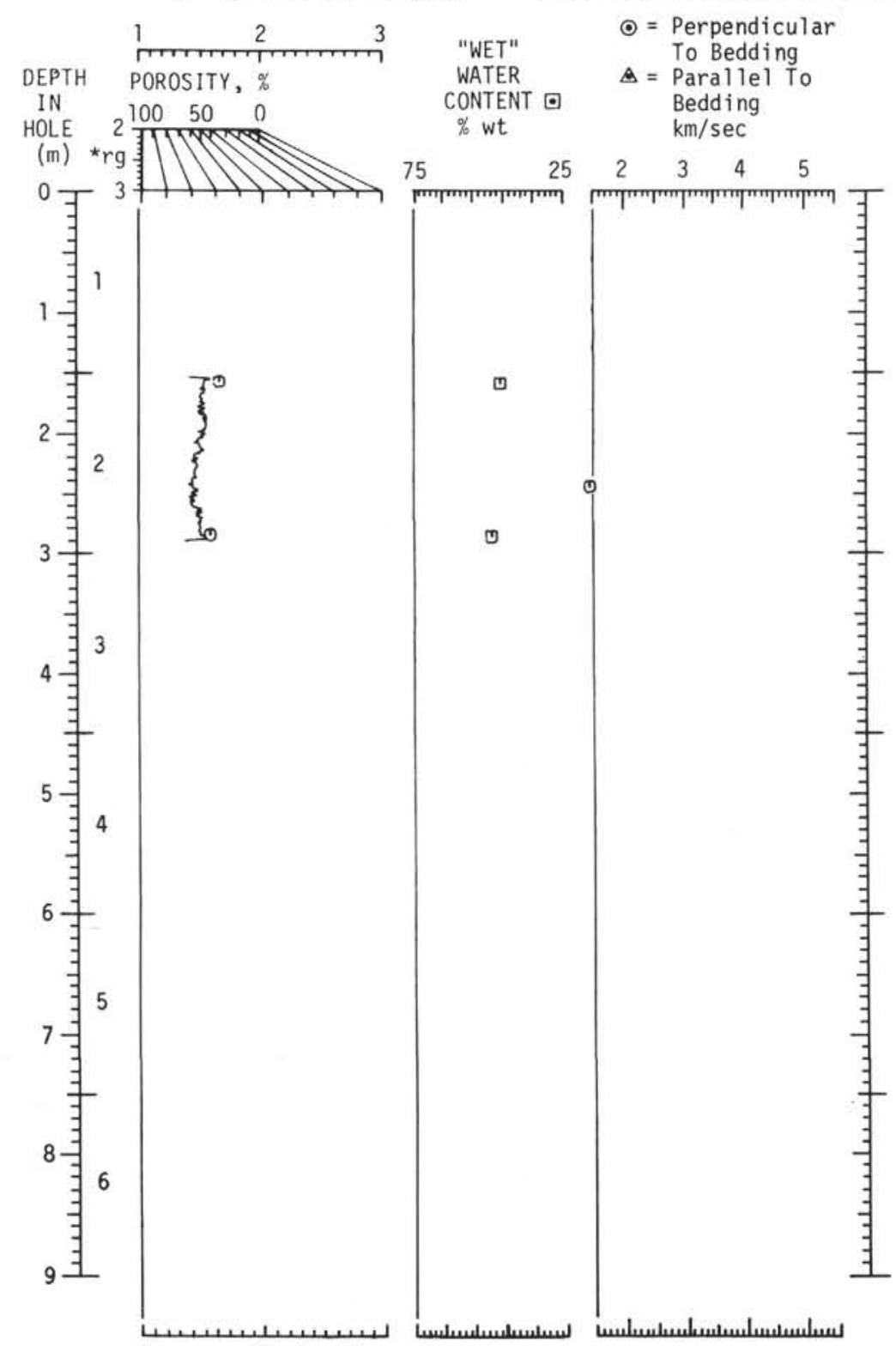

$*_{r g}=$ grain density, g/cc
- = GRAPE WET-BULK DENSITY, g/cC

- Syringe porosity, \% COMPRESSIONAL SOUND VELOCITY

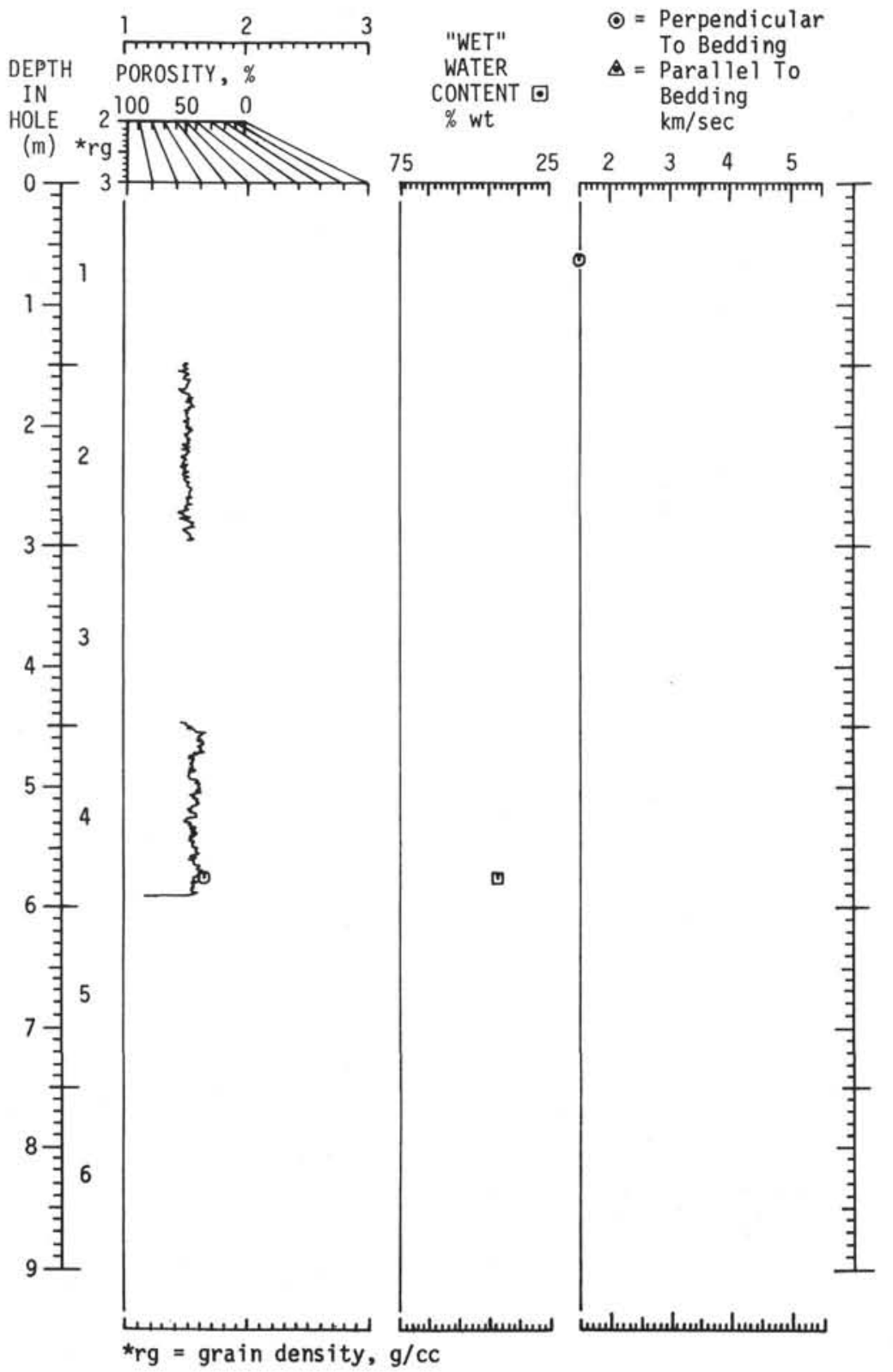


CORE 310-3

- $=$ GRAPE WET-BULK DENSITY, $\mathrm{g} / \mathrm{cC}$.

- Syringe porosity, \% COMPRESSIONAL SOUND VELOCITY

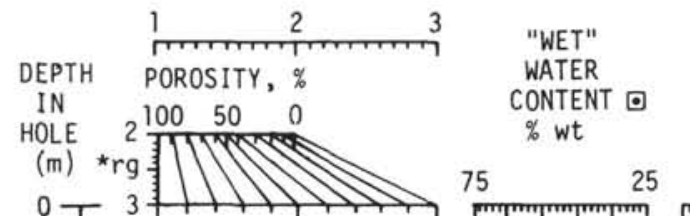

$\odot=$ Perpendicular To Bedding

= Parallel To Bedding 25

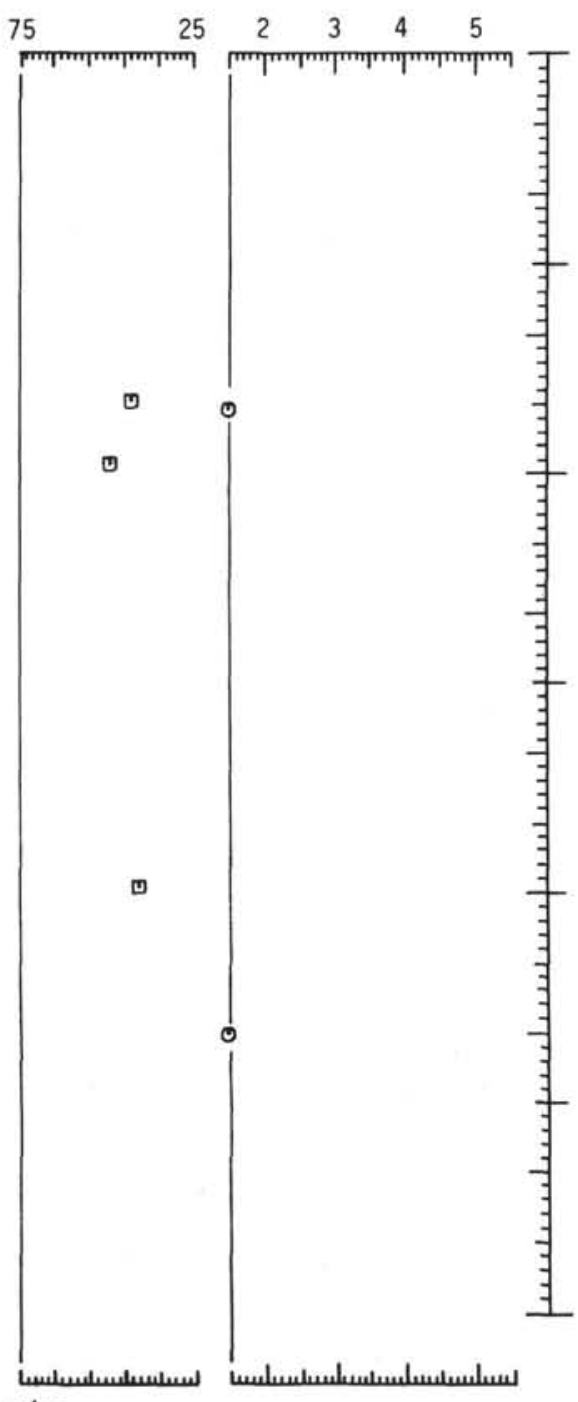

CORE

$310-4$

- $=$ GRAPE WET-BULK DENSITY, $g / c C$

○ Syringe porosity, \%

COMPRESSIONAL SOUND VELOCITY

\begin{tabular}{|c|c|c|c|c|}
\hline & 1 & 2 & & $\odot=$ Perpendicular \\
\hline DEPT & POROSITY, & $\%$ & $\begin{array}{l}\text { "WET" } \\
\text { WATER }\end{array}$ & $\begin{aligned} & \text { To Bedding } \\
\Delta= & \text { Parallel To }\end{aligned}$ \\
\hline $\begin{array}{l}\text { IN } \\
\text { HOLE }\end{array}$ & $2100 \quad 50$ & 0 & $\begin{array}{l}\text { CONTENT ■ } \\
\% \text { wt }\end{array}$ & $\begin{array}{l}\text { Bedding } \\
\mathrm{km} / \mathrm{sec}\end{array}$ \\
\hline
\end{tabular}

(m) 2 गा

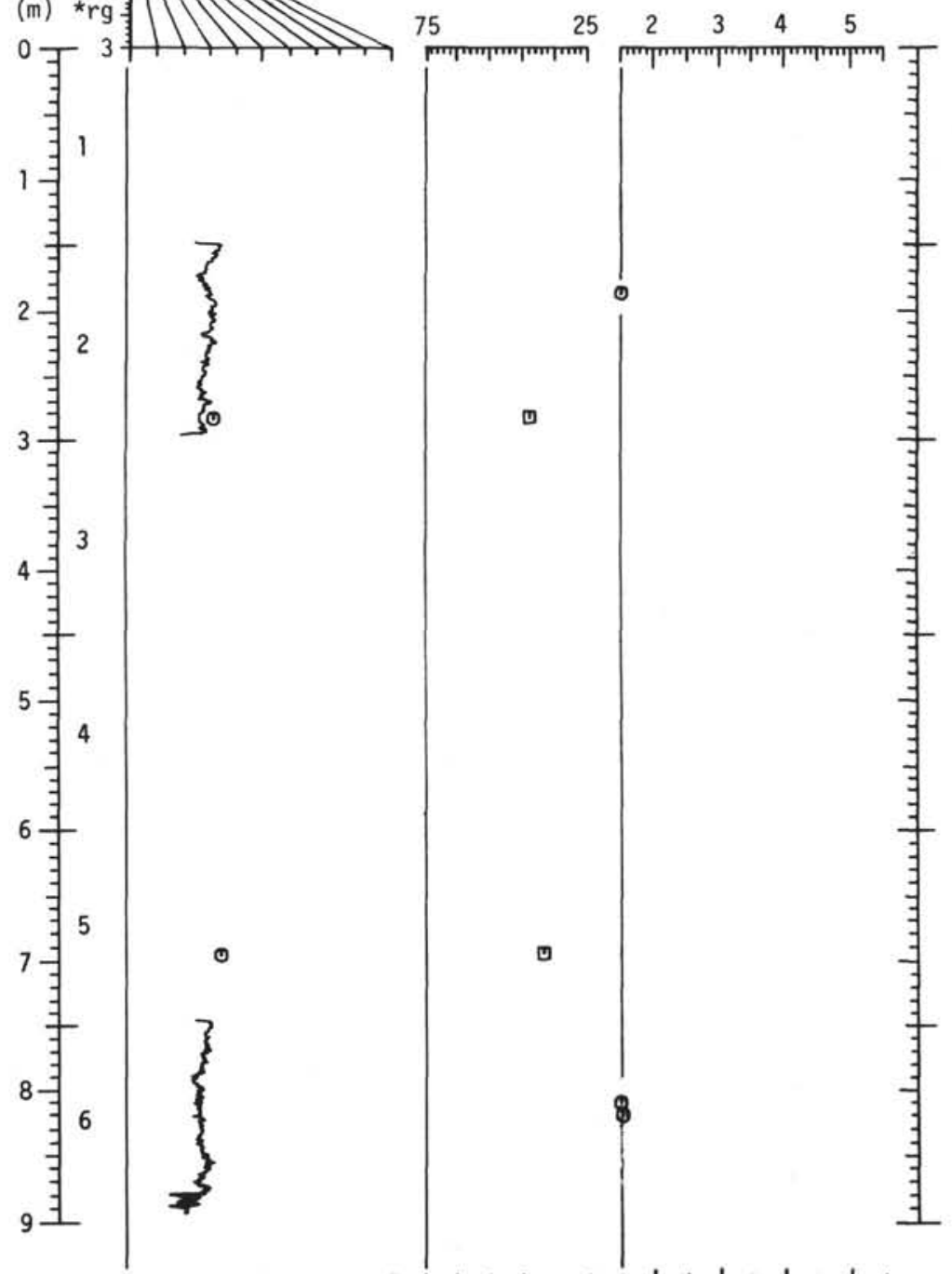

${ }^{*} r g=$ grain density, g/cc 
- = GRAPE WET-BULK DENSITY, g/cC

๑ Syringe porosity, \%

COMPRESSIONAL SOUND VELOCITY

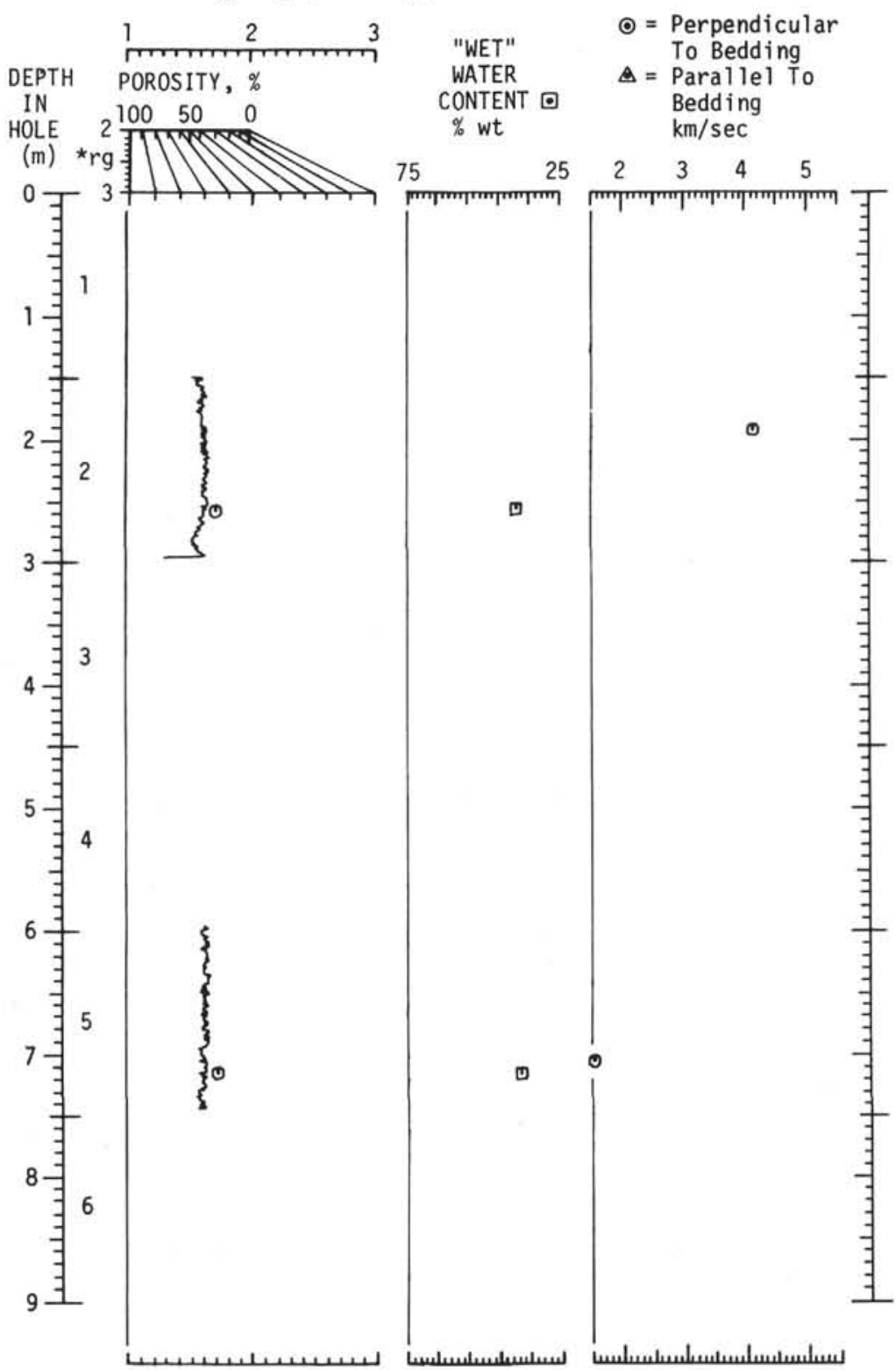

${ }^{*} \mathrm{rg}=$ grain density, $g / c c$
- $=$ GRAPE WET-BULK DENSITY, $g / c c$

๑ Syringe porosity, \%

COMPRESSIONAL SOUND VELOCITY

\begin{tabular}{|c|c|c|c|c|}
\hline & 1 & 2 & & $\odot=$ Perpendicular \\
\hline EPTH & POROSITY, & $\%$ & WATER & $\Delta=$ Parallel To \\
\hline IN & $2100 \quad 50$ & 0 & CONTENT ए & Bedding \\
\hline
\end{tabular}

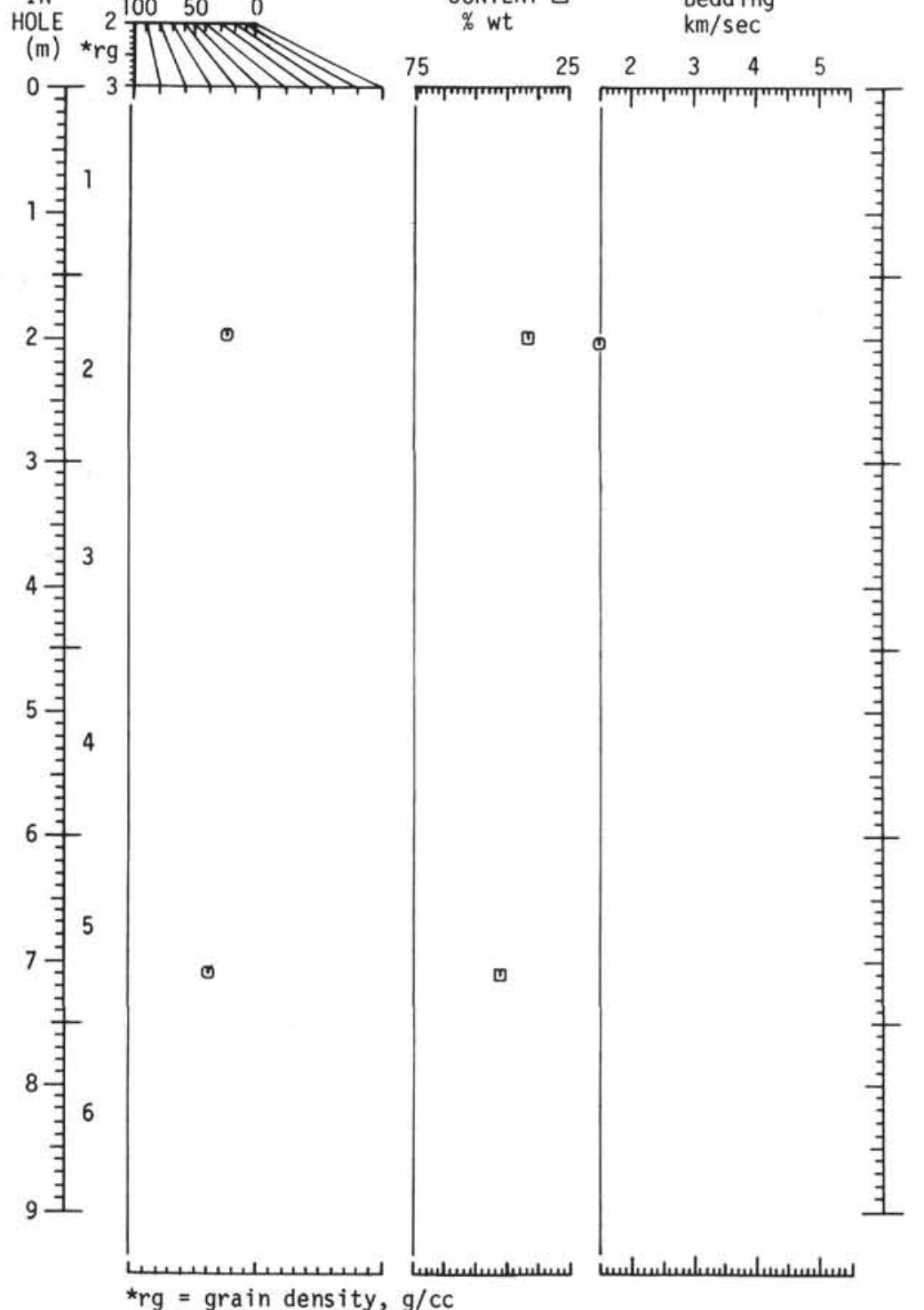


CORE 310-7

- $=$ GRAPE WET - BULK DENSITY, $\mathrm{g} / \mathrm{cC}$

- Syringe porosity, \% COMPRESSIONAL SOUND VELOCITY

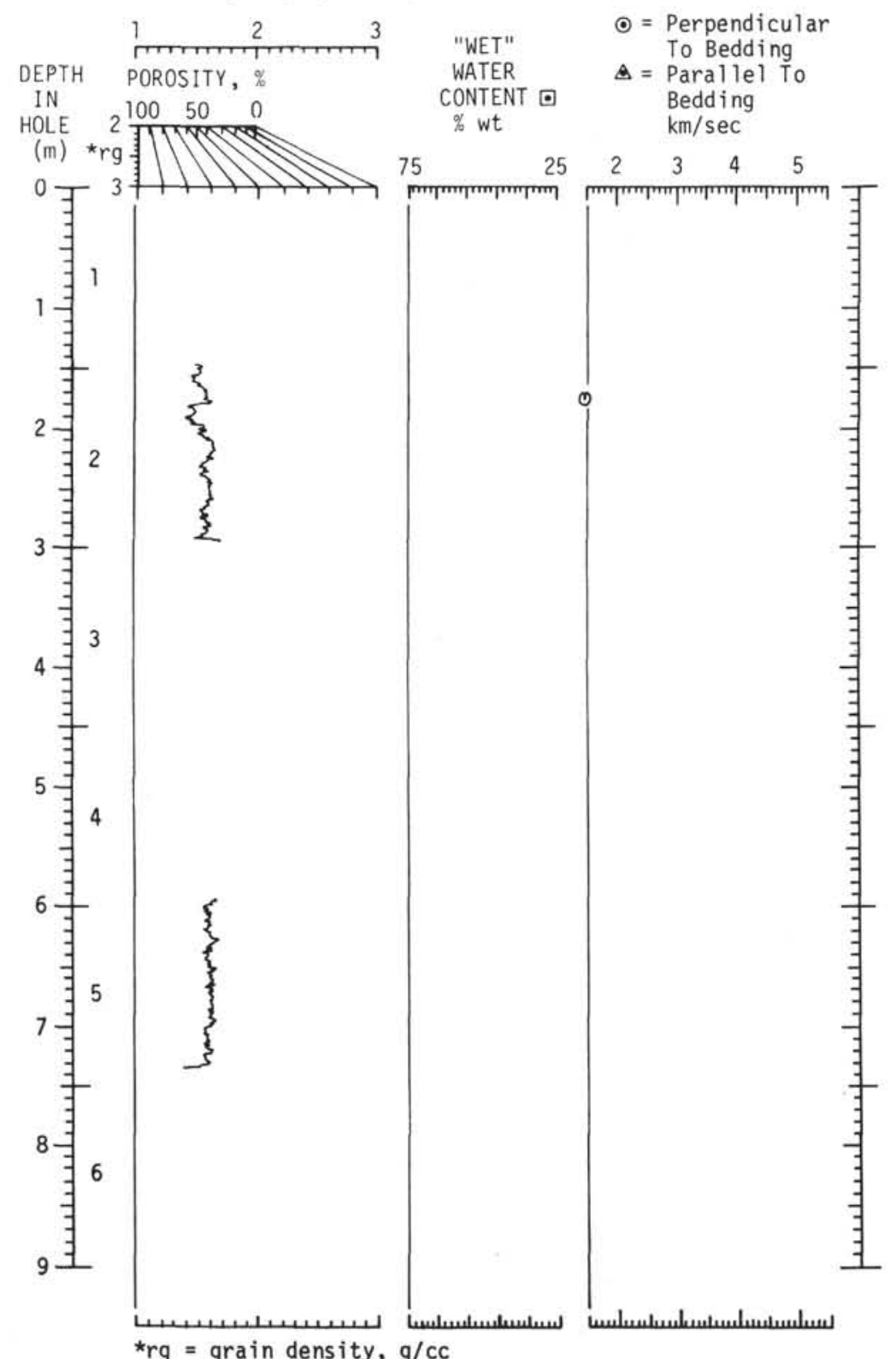

CORE $310-8$

- = GRAPE WET-BULK DENSITY, $\mathrm{g} / \mathrm{cC}$

- Syringe porosity, \% COMPRESSIONAL SOUND VELOCITY

\begin{tabular}{|c|c|c|c|c|}
\hline & 1 & $2^{2}, 3^{3}$ & "WET" & $\begin{aligned} \odot= & \text { Perpendicular } \\
& \text { To Bedding }\end{aligned}$ \\
\hline EPTH & POROSITY, & $\%$ & WATER & $\Delta=$ Parallel To \\
\hline $\begin{array}{l}\text { IN } \\
\text { OLLE }\end{array}$ & $2100 \quad 50$ & 0 & $\begin{array}{l}\text { CONTENT @ } \\
\% \text { wt }\end{array}$ & $\begin{array}{l}\text { Bedding } \\
\mathrm{km} / \mathrm{sec}\end{array}$ \\
\hline
\end{tabular}

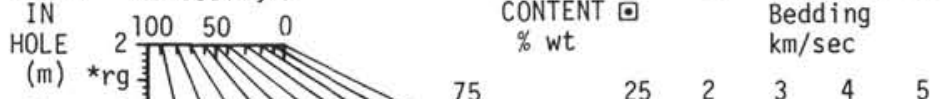

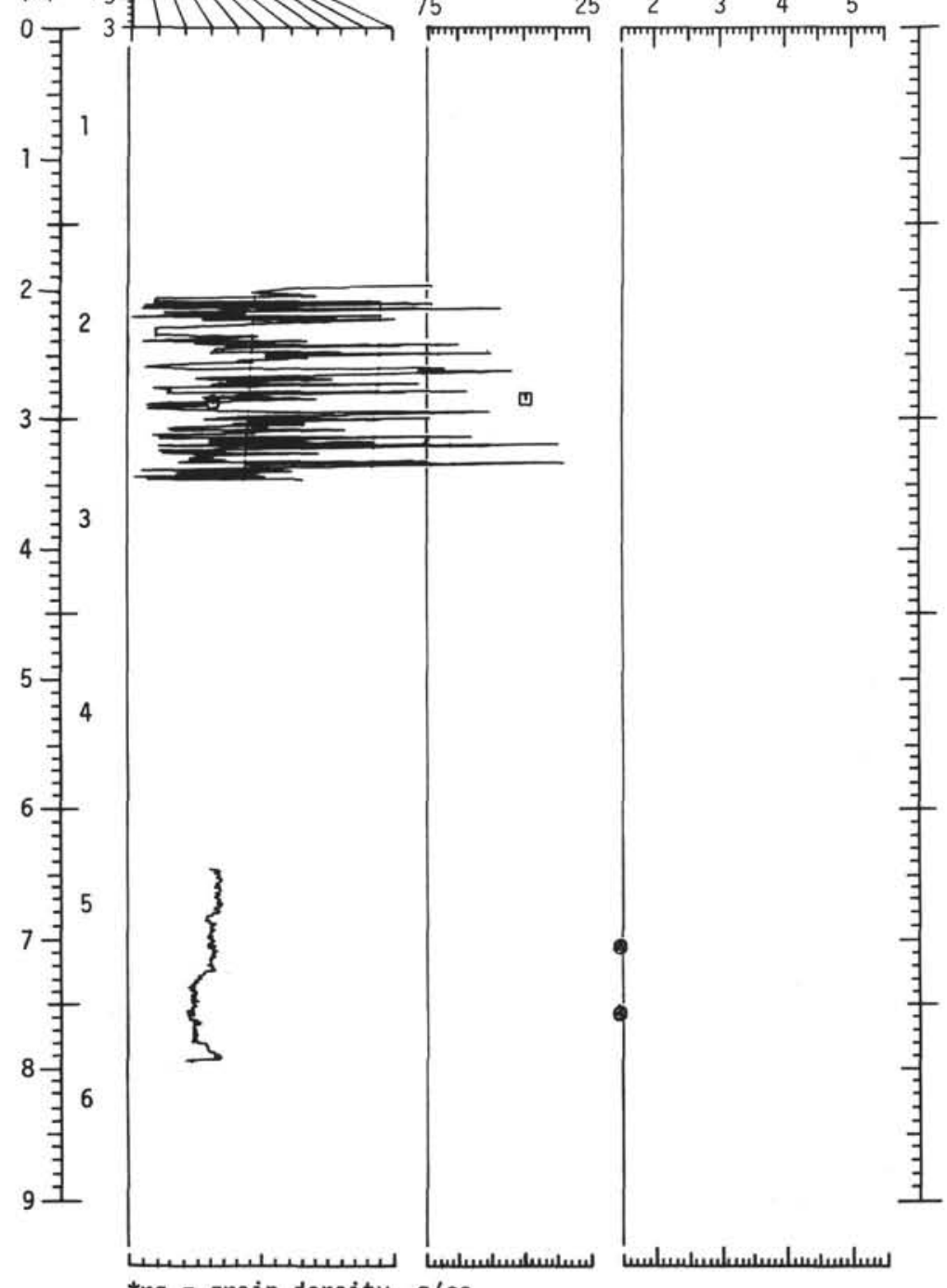


- $=$ GRAPE WET-BULK DENSITY, $g / c C$

- Syringe porosity, $\%$ COMPRESSIONAL SOUND VELOCITY

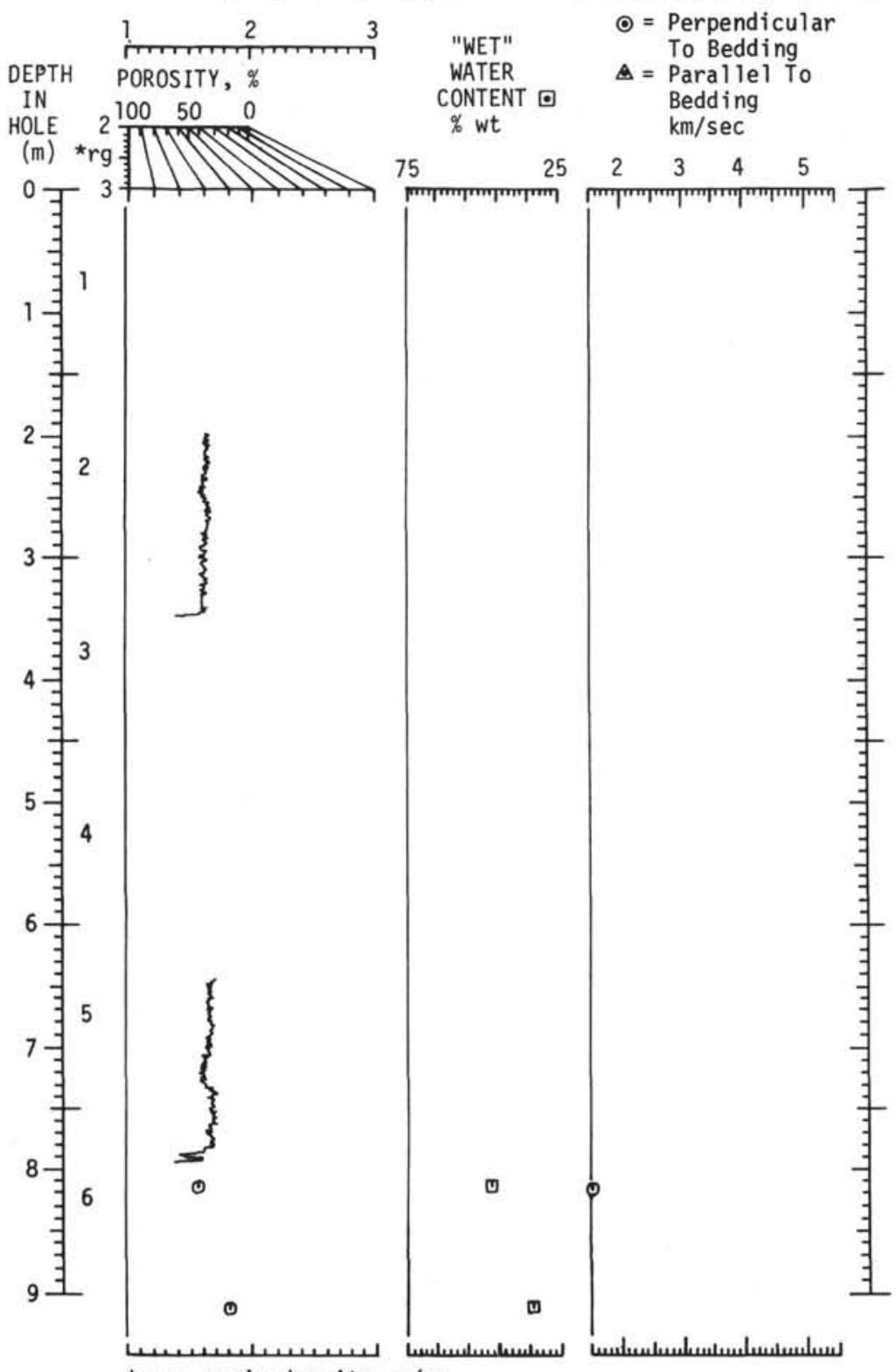

- $=$ GRAPE WET-BULK DENSITY, g/cc.

- Syringe porosity, \% COMPRESSIONAL SOUND VELOCITY

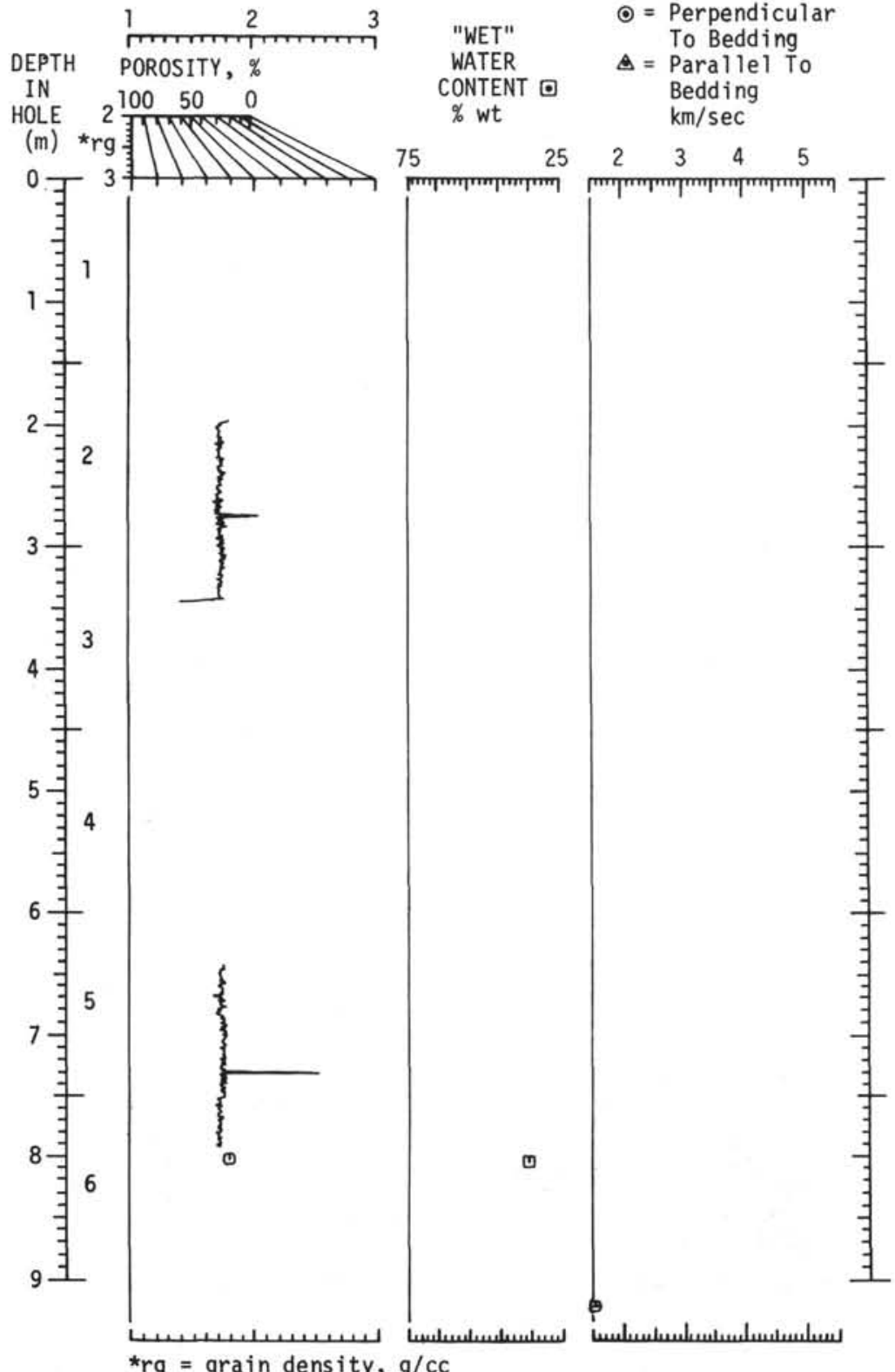


CORE 310-11

- $=$ GRAPE WET-BULK DENSITY, $\mathrm{g} / \mathrm{cc}$

- Syringe porosity, \% COMPRESSIONAL SOUND VELOCITY

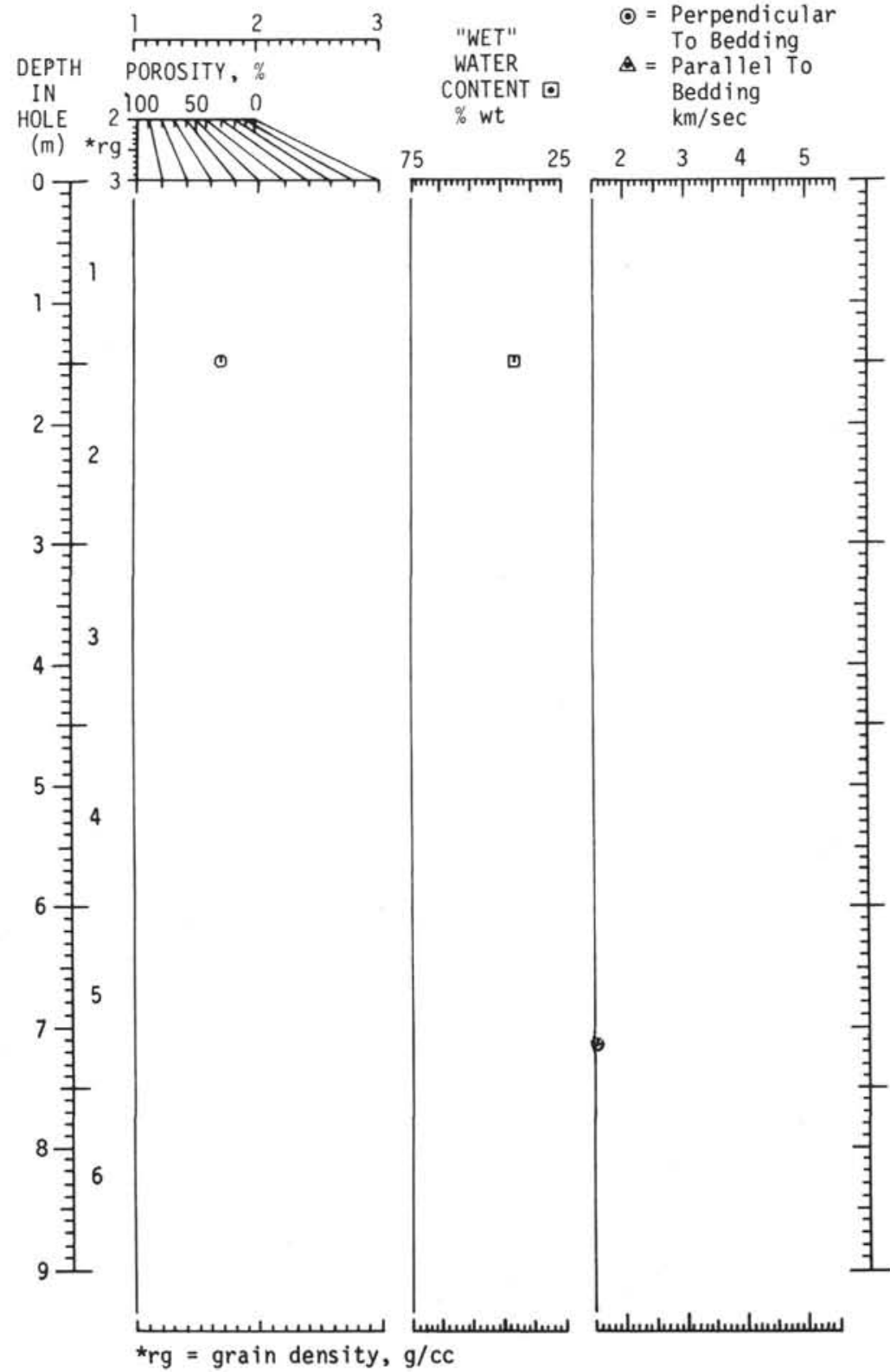

CORE 310-12

- $=$ GRAPE WET-BULK DENSITY, $g / c c$

- Syringe porosity, \%

COMPRESSIONAL SOUND VELOCITY

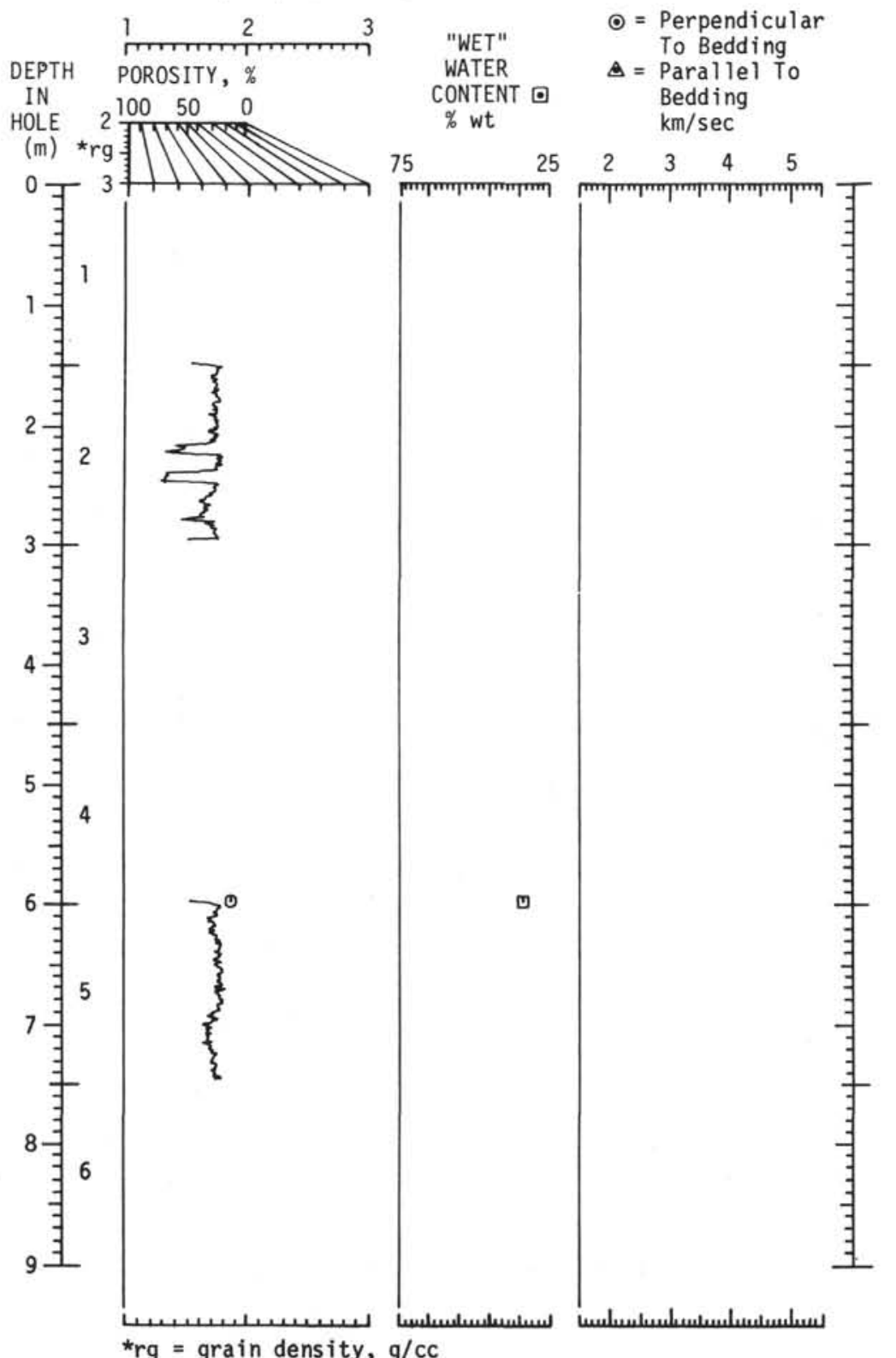


- Syringe porosity, \% COMPRESSIONAL SOUND VELOCITY

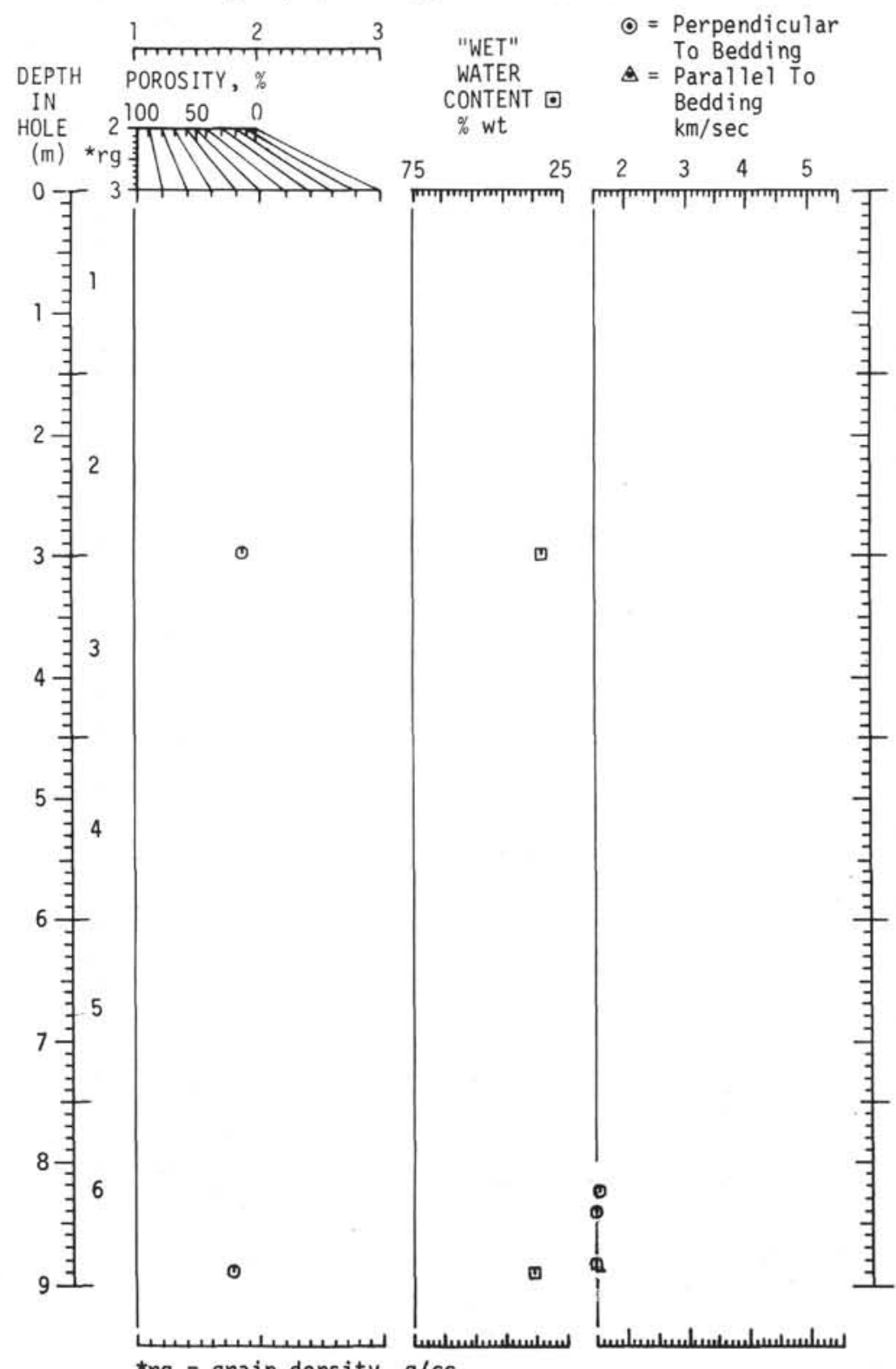

CORE

310-14

$-=$ GRAPE WET-BULK DENSITY, $g / c C$

- Syringe porosity, \% COMPRESSIONAL SOUND VELOCITY

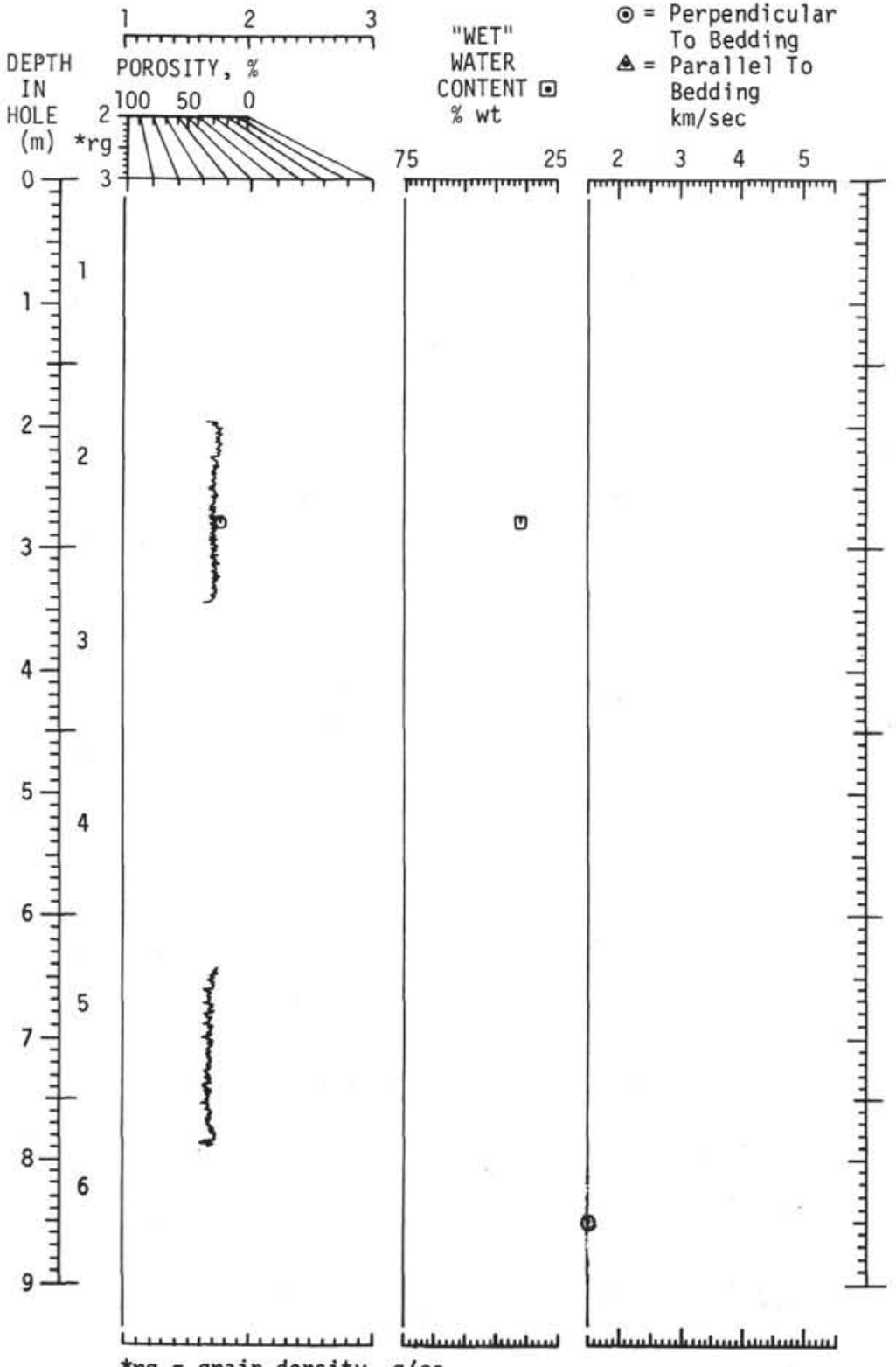


CORE $\quad 310-16$

- = GRAPE WET-BULK DENSITY, g/cC

- Syringe porosity, \% COMPRESSIONAL SOUND VELOCITY

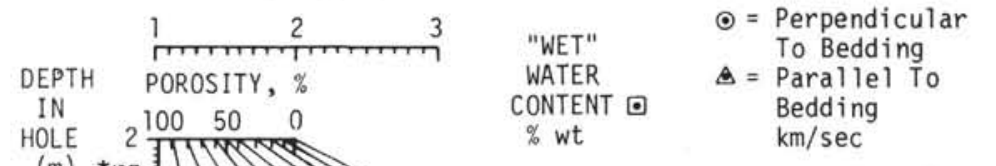

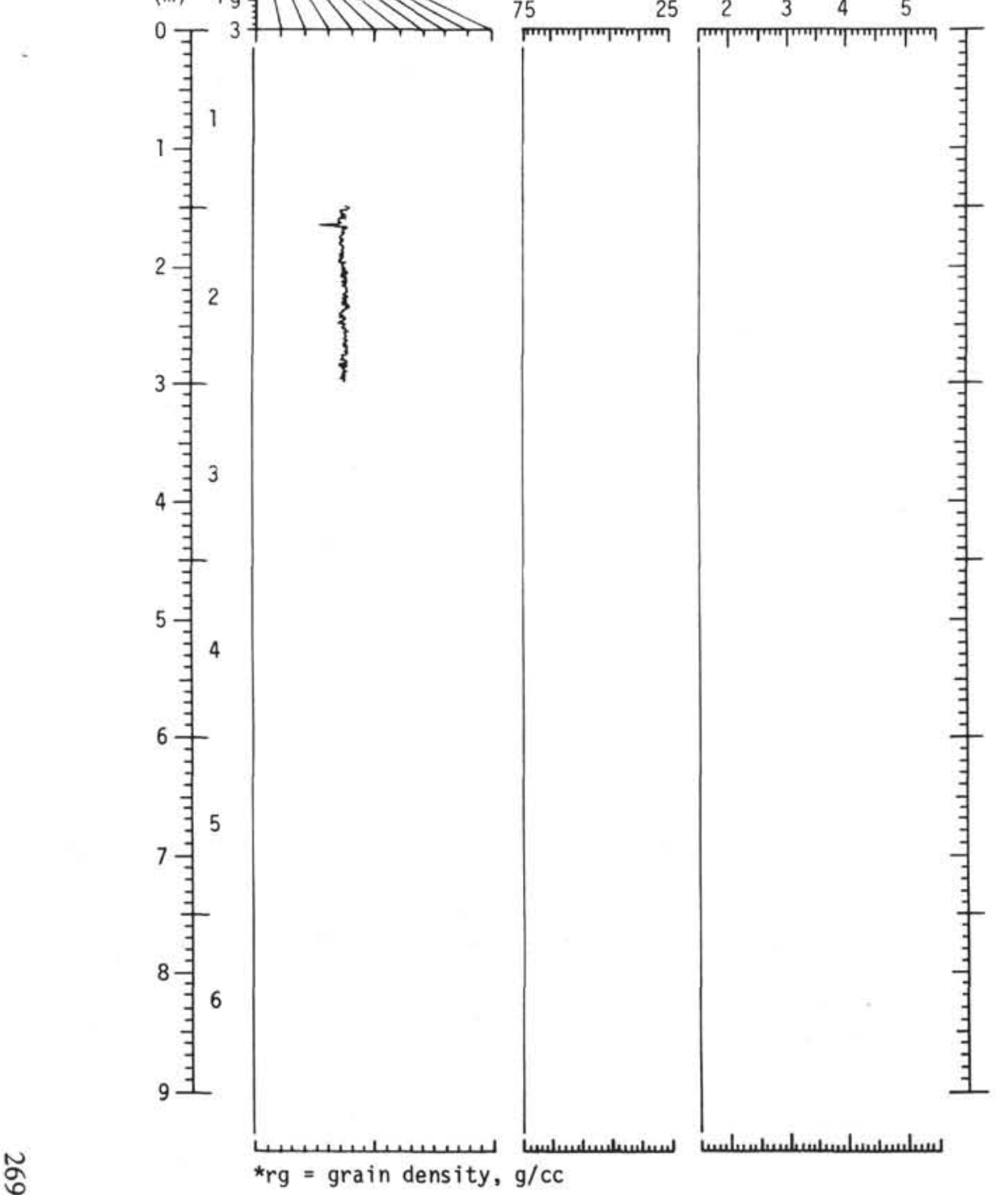

CORE $\quad 310-17$

- = GRAPE WET-BULK DENSITY, $\mathrm{g} / \mathrm{cC}$

॰ Syringe porosity, \% COMPRESSIONAL SOUND VELOCITY

\begin{tabular}{|c|c|c|c|}
\hline & 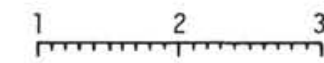 & "WET" & $\begin{aligned} \odot= & \text { Perpendicular } \\
& \text { To Bedding }\end{aligned}$ \\
\hline $\begin{array}{l}\text { DEPTH } \\
\text { IN }\end{array}$ & POROSITY, \% & WATER & $\Delta=$ Parallel To \\
\hline HOLE & $2100 \quad 50 \quad 0$ & $\%$ wt & $\begin{array}{l}\text { Bedding } \\
\mathrm{km} / \mathrm{sec}\end{array}$ \\
\hline
\end{tabular}

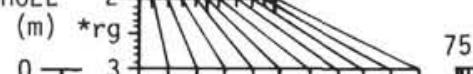

$\begin{array}{lllll}25 & 2 & 3 & 4 & 5\end{array}$

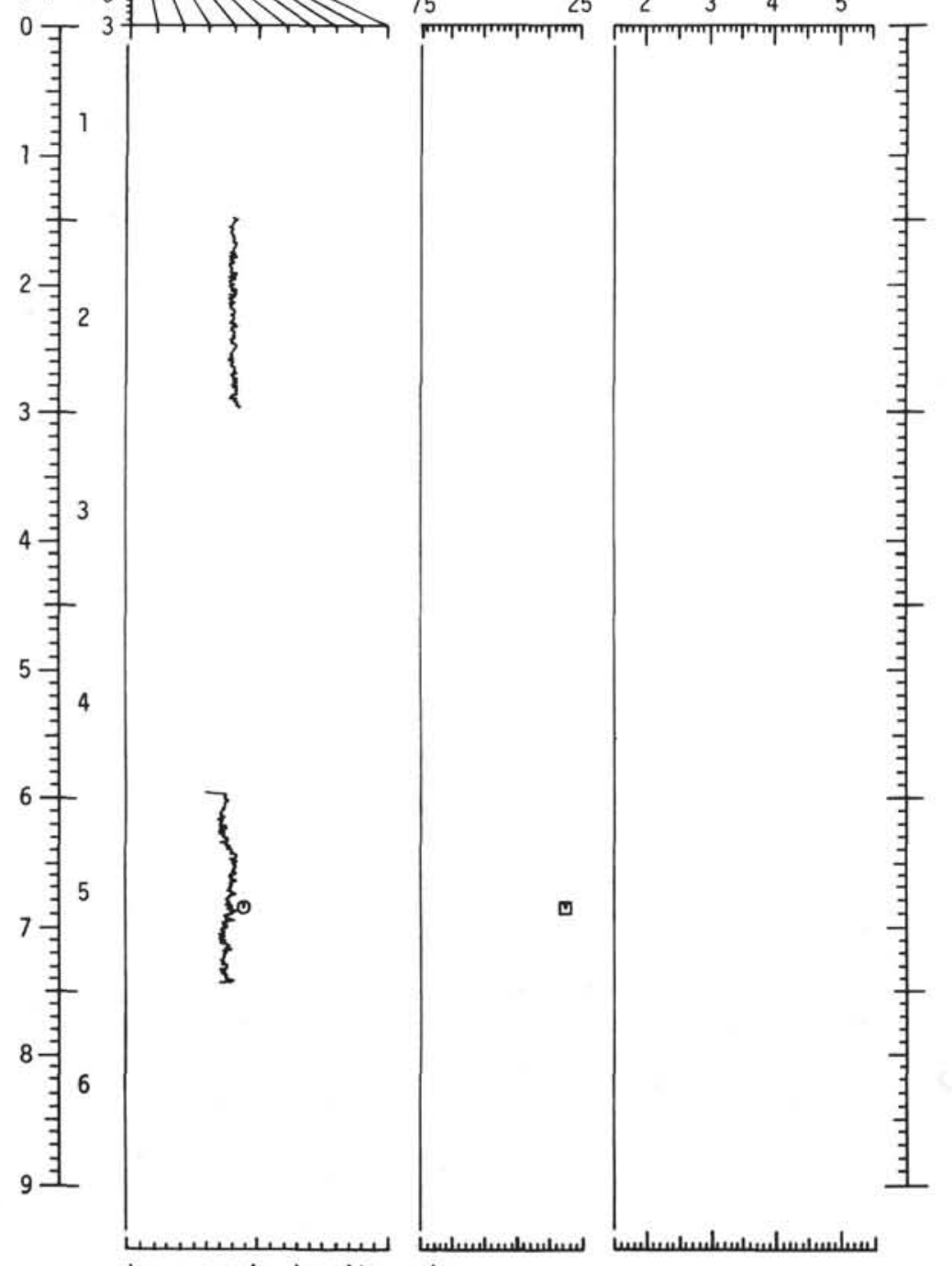

$\star_{r} g=$ grain density, g/cc 
○ Syringe porosity, \% COMPRESSIONAL SOUND VELOCITY

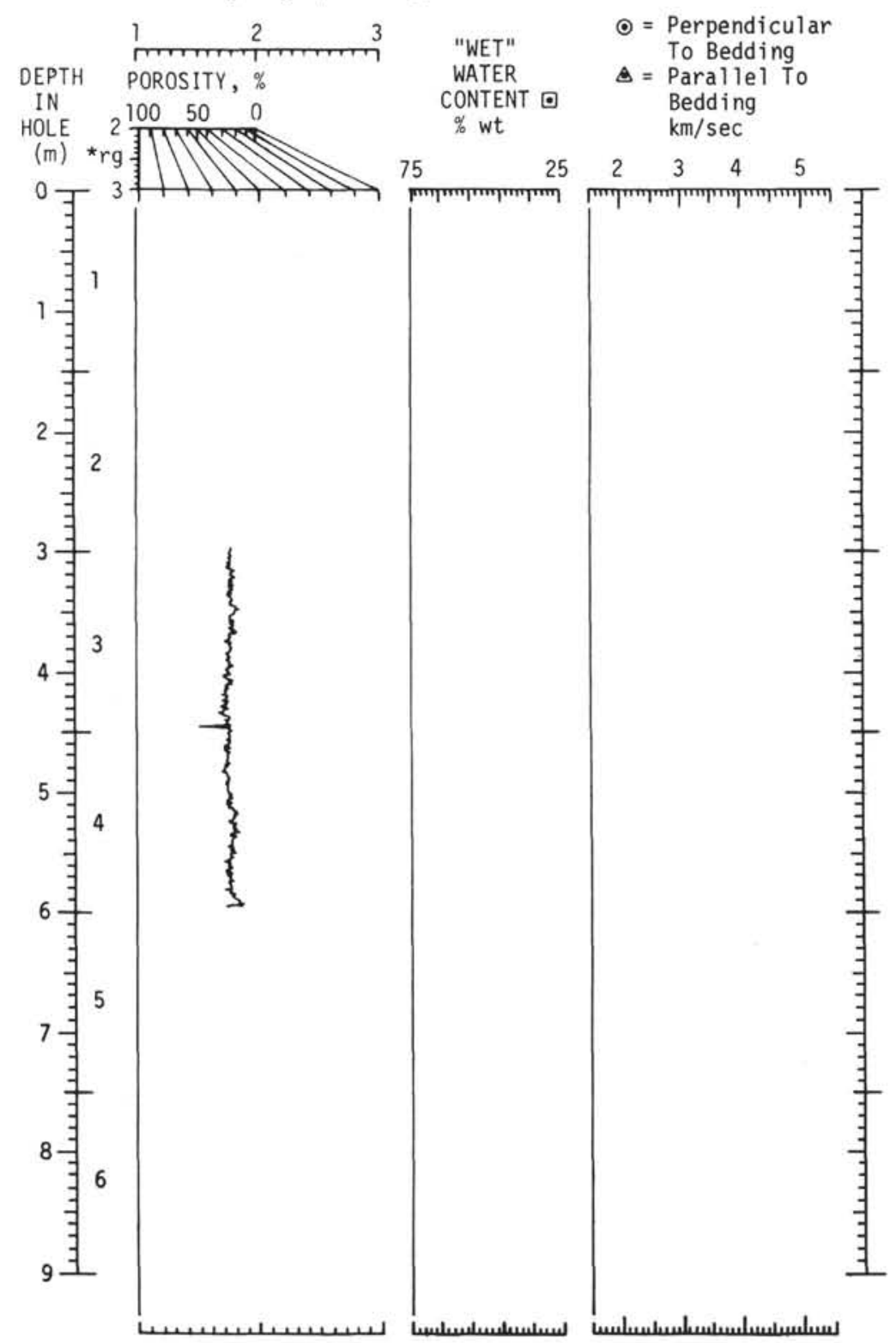

$*_{r g}=$ grain density, $\mathrm{g} / \mathrm{cc}$
- $=$ GRAPE WET-BULK DENSITY, g/cC.

- Syringe porosity, \% COMPRESSIONAL SOUND VELOCITY

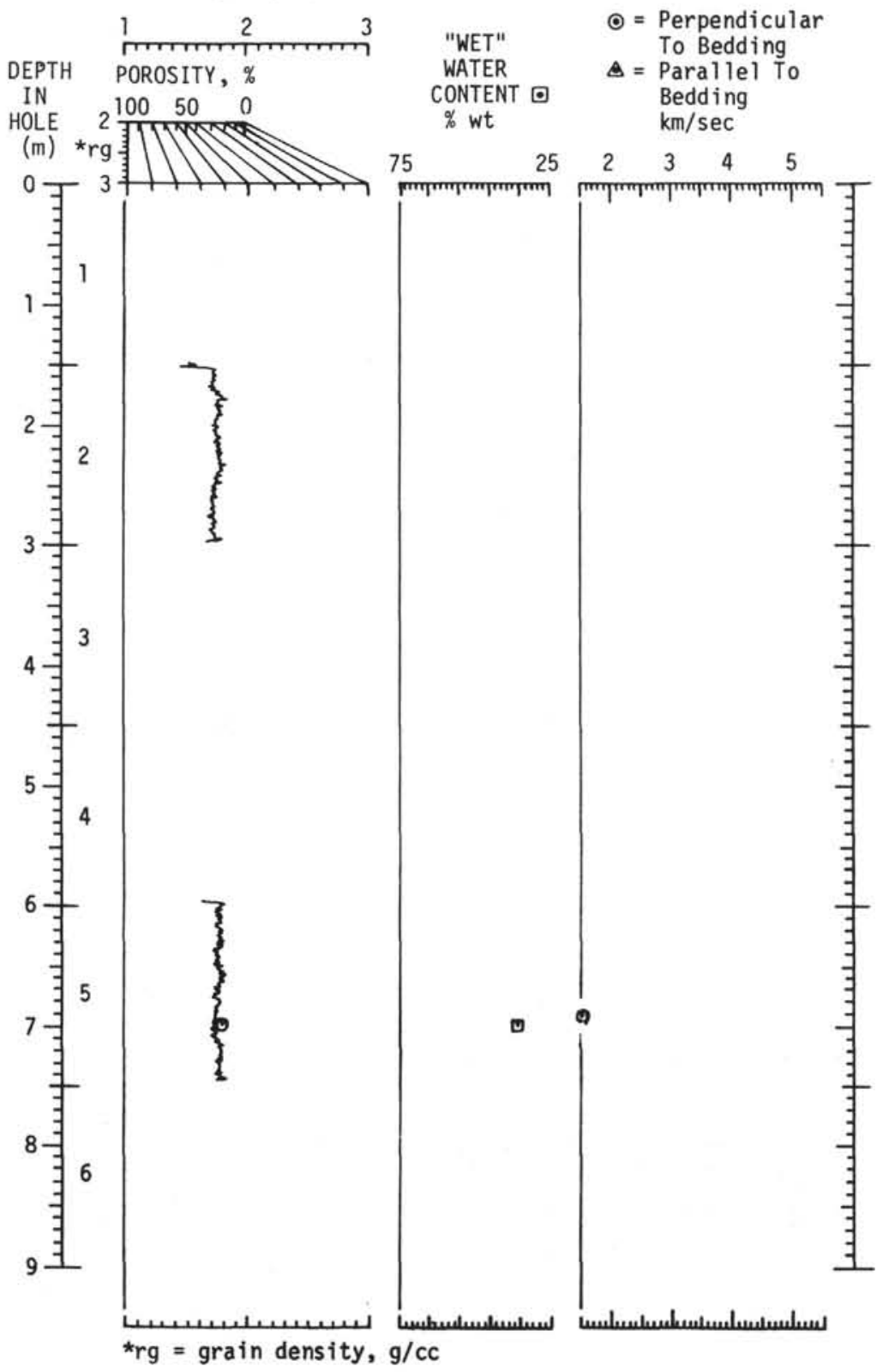


CORE $310 A-2$

- = GRAPE WET-BULK DENSITY, g/CC

๑ Syringe porosity, \%

COMPRESSIONAL SOUND VELOCITY

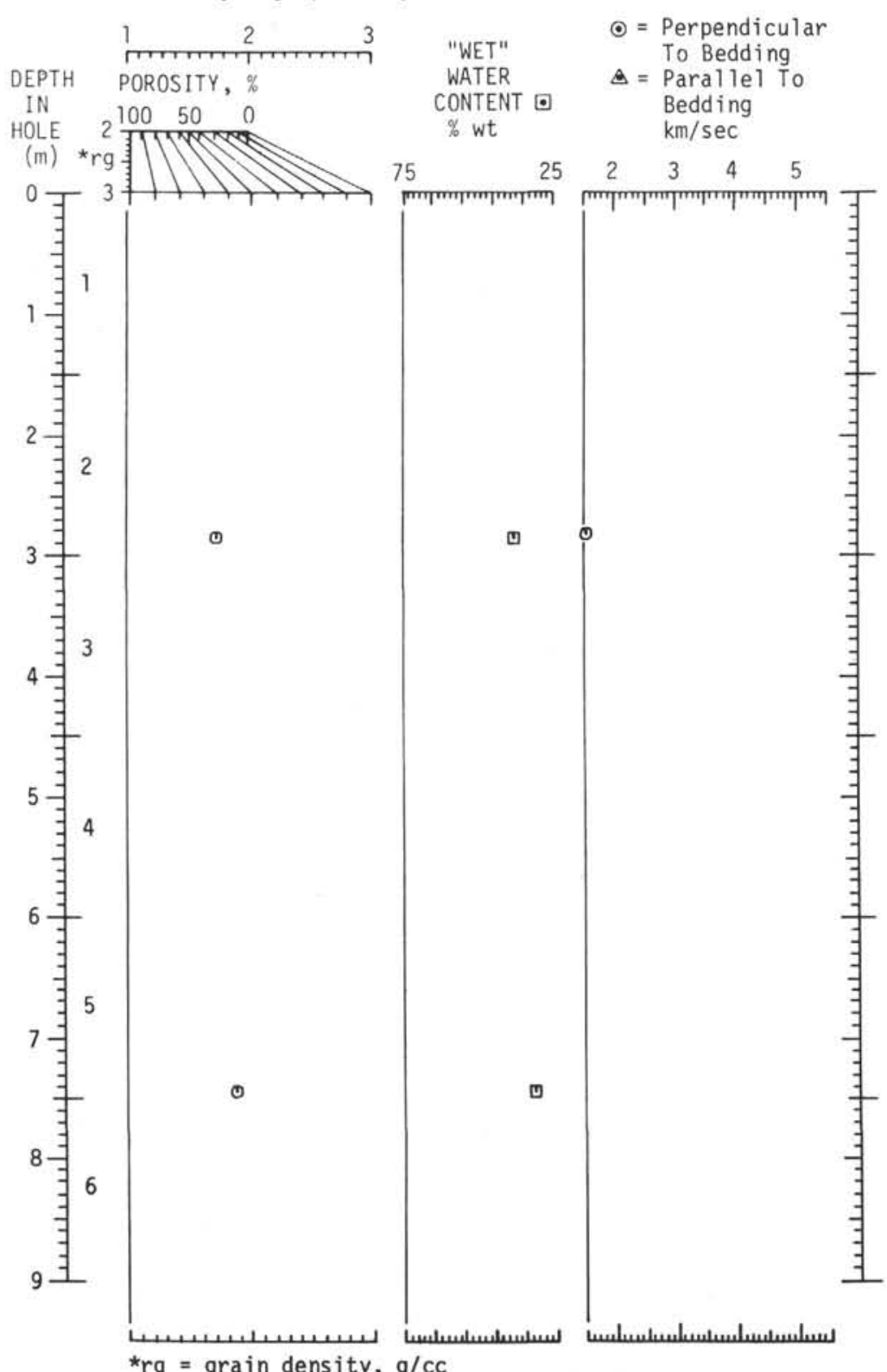

CORE $310 A-5$

- $=$ GRAPE WET-BULK DENSITY, g/cc

- Syringe porosity, \%

COMPRESSIONAL SOUND VELOCITY

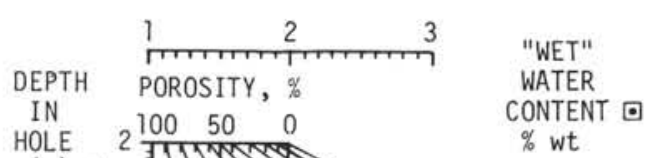

$\odot=$ Perpendicular

To Bedding

$\Delta=$ Parallel $\mathrm{To}$

HOLE 2 100 $50 \quad 0 \quad \%$ wt $\quad \begin{aligned} & \text { Bedding } \\ & \mathrm{km} / \mathrm{sec}\end{aligned}$

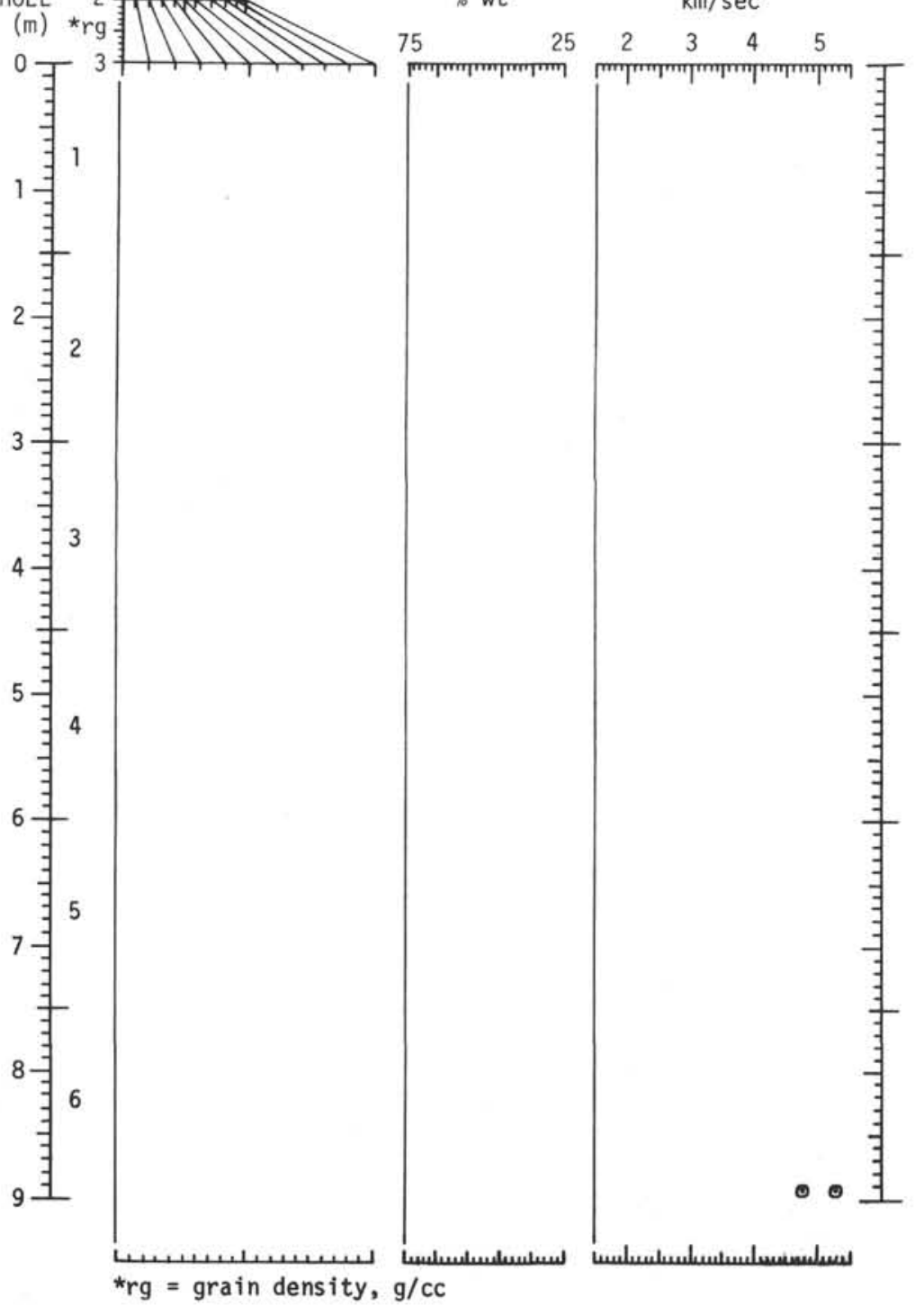


CORE $310 A-9$

- $=$ GRAPE WET-BULK DENSITY, $\mathrm{g} / \mathrm{CC}$

○ Syringe porosity, \% COMPRESSIONAL SOUND VELOCITY

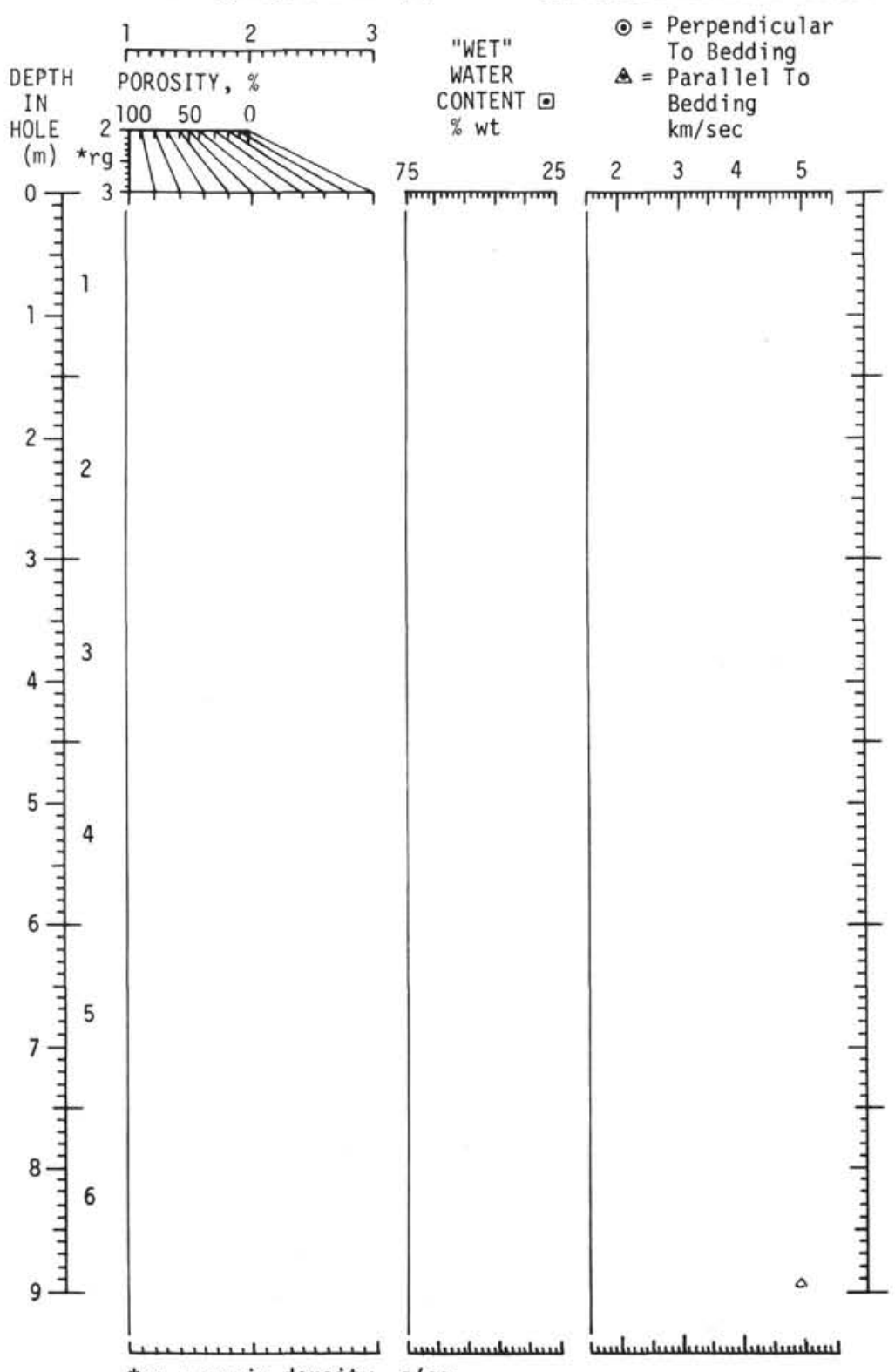

CORE $310 \mathrm{~A}-11$

- Syringe porosity, \% COMPRESSIONAL SOUND VELOCITY

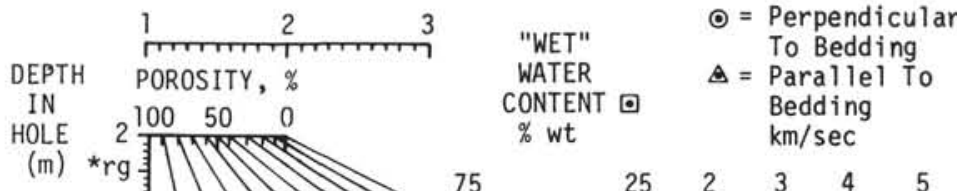

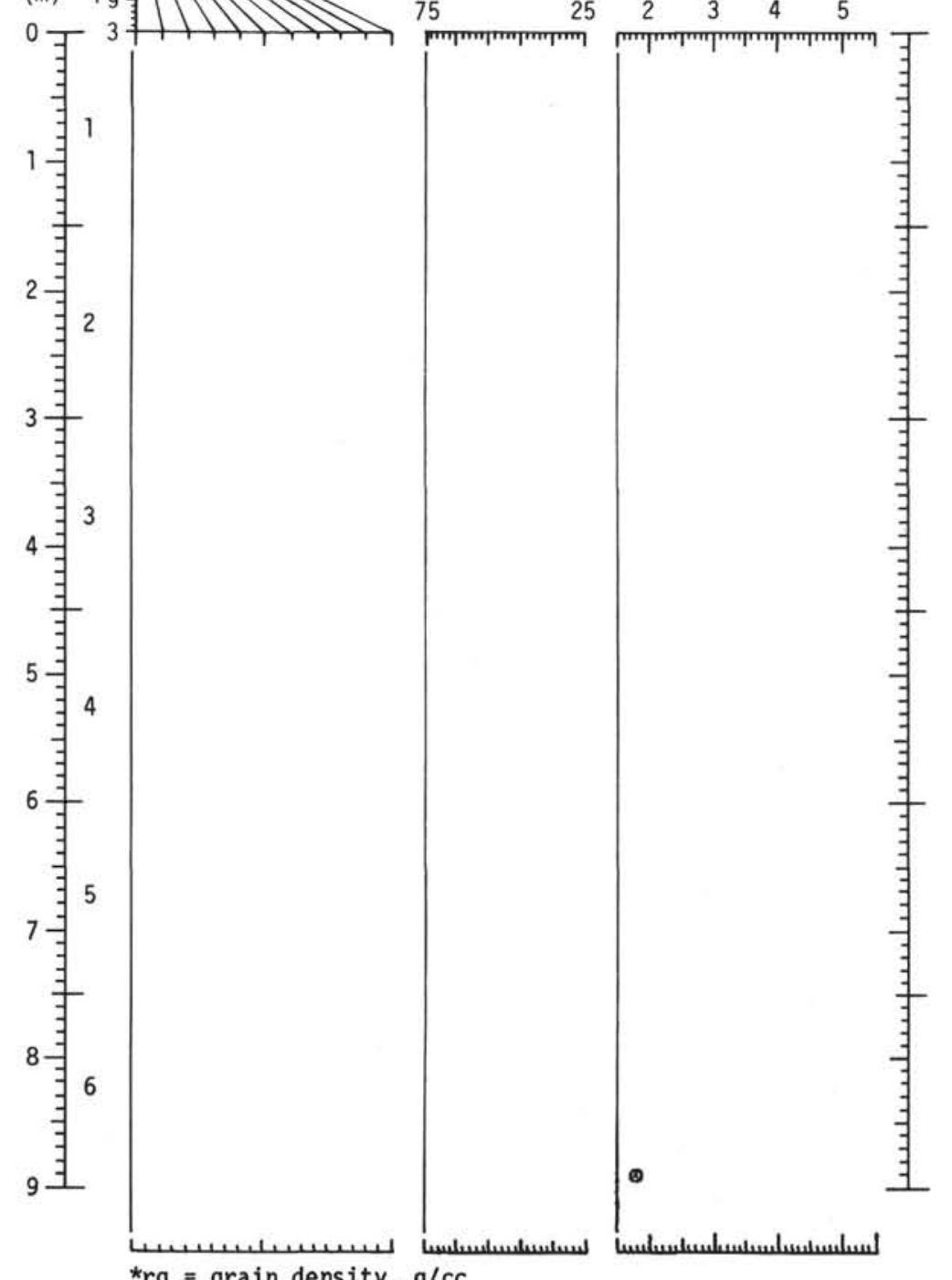


CORE $310 \mathrm{~A}-12$

- = GRAPE WET-BULK DENSITY, g/cC

- Syringe porosity, \% COMPRESSIONAL SOUND VELOCITY

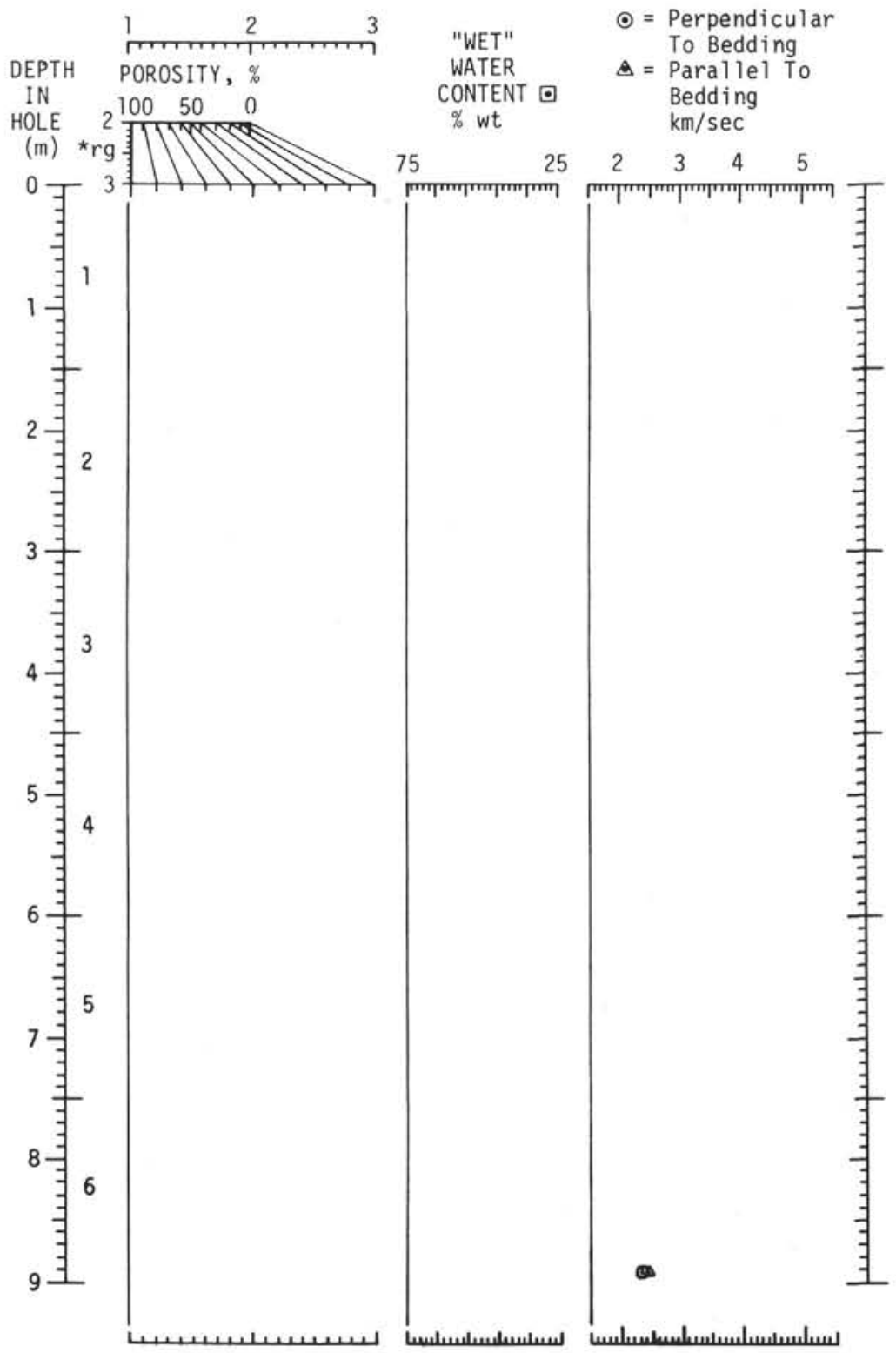

${ }^{*} r g=$ grain density, $g / c c$ 


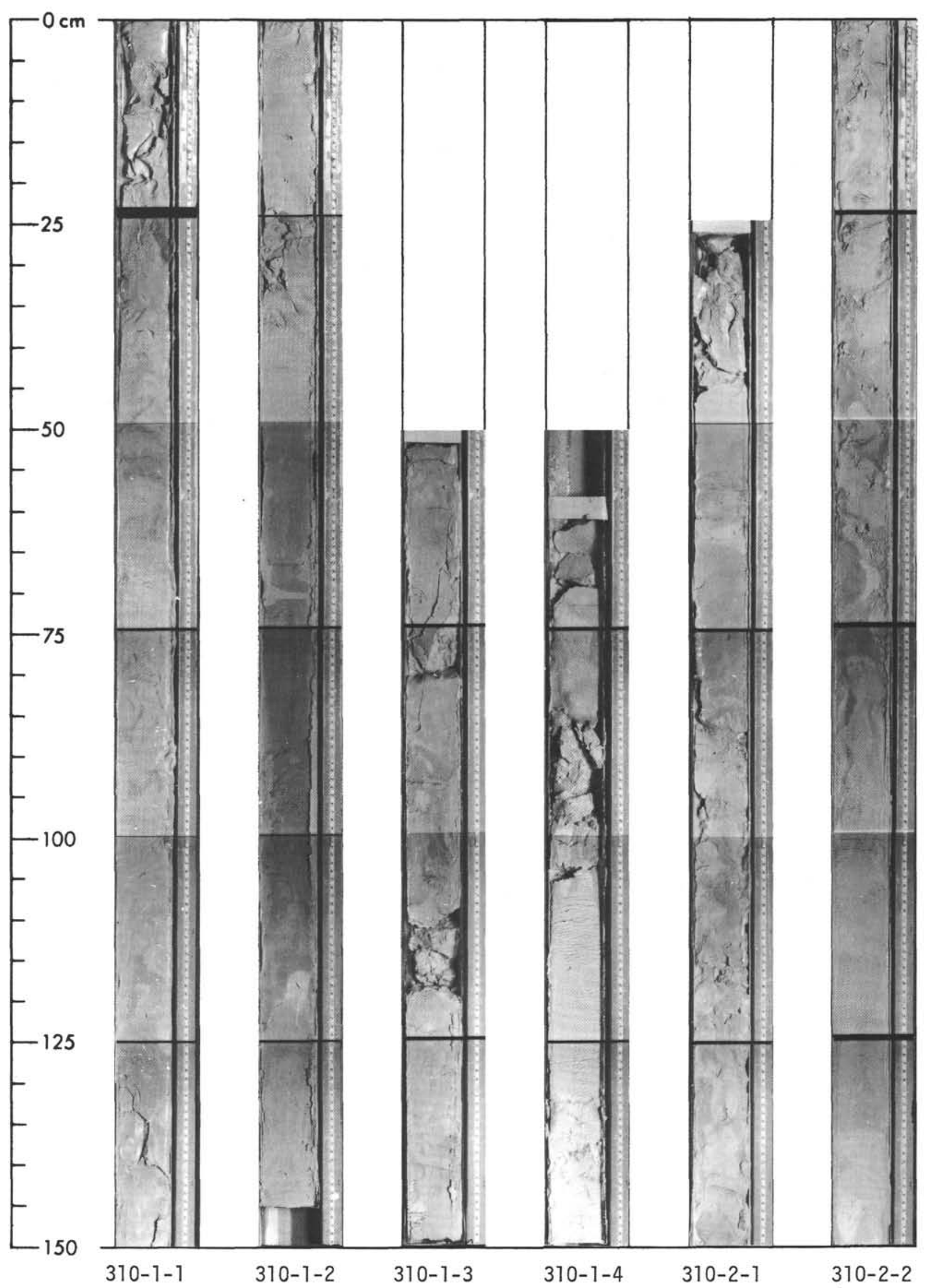


SITE 310

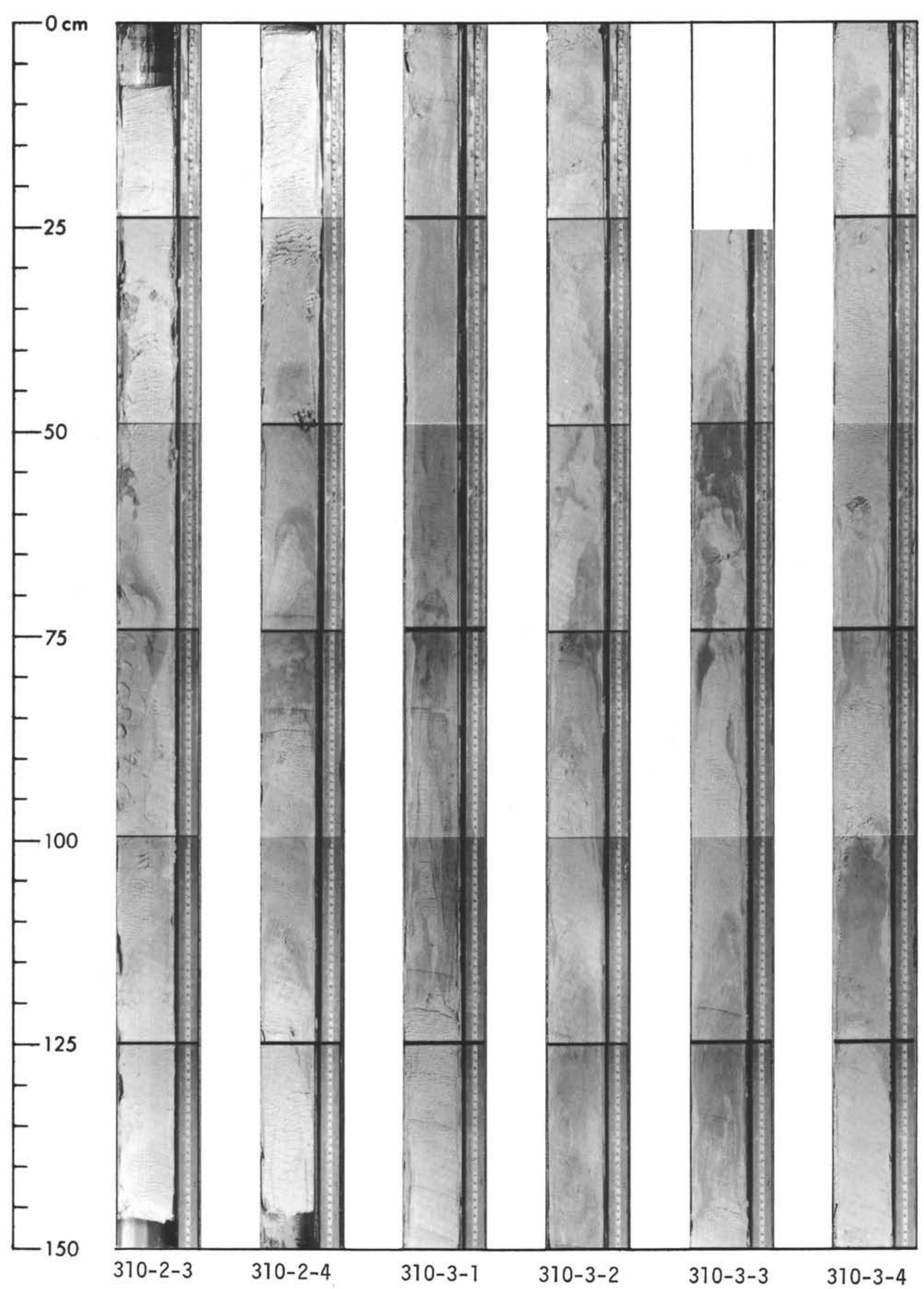




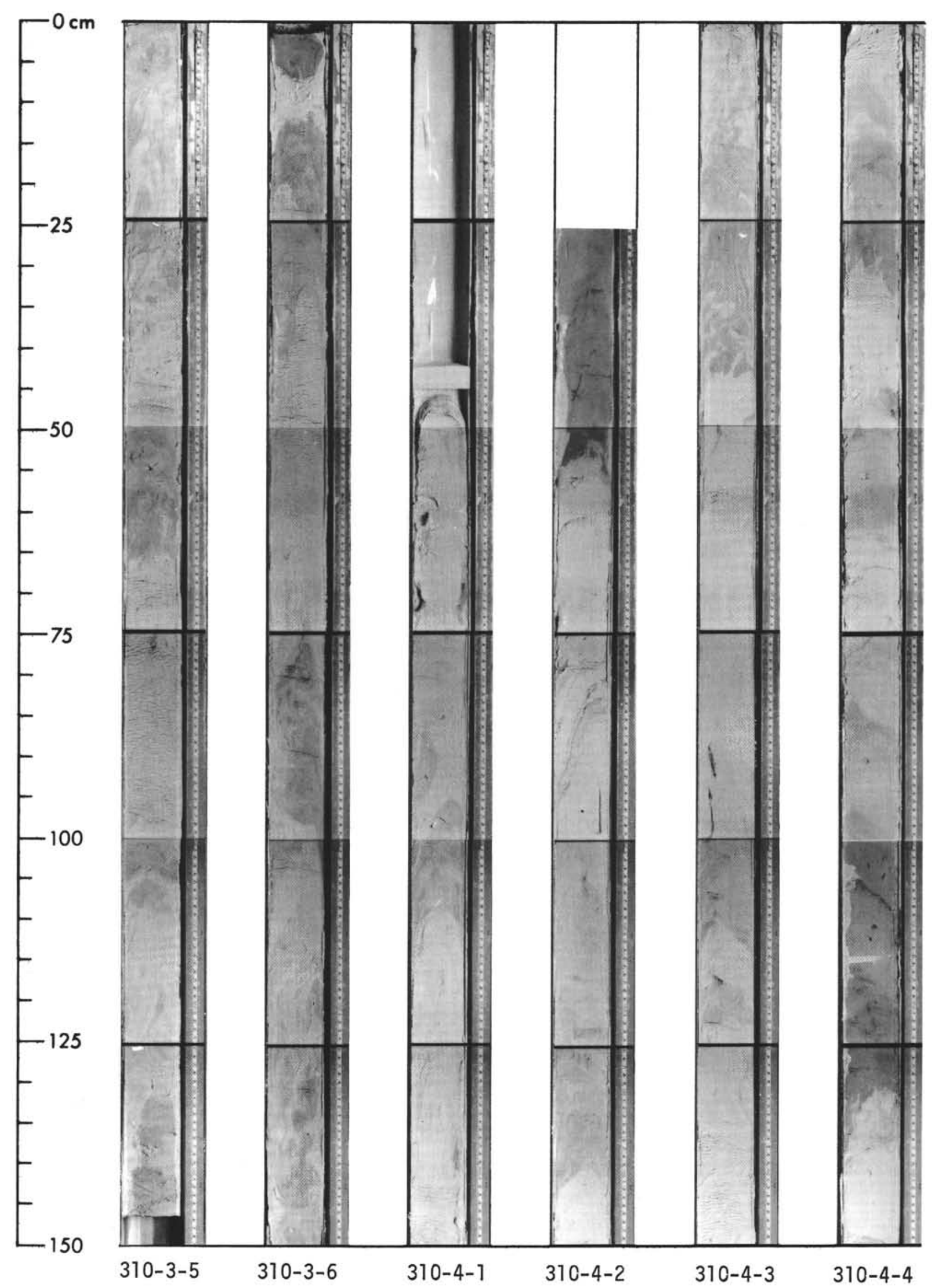


SITE 310

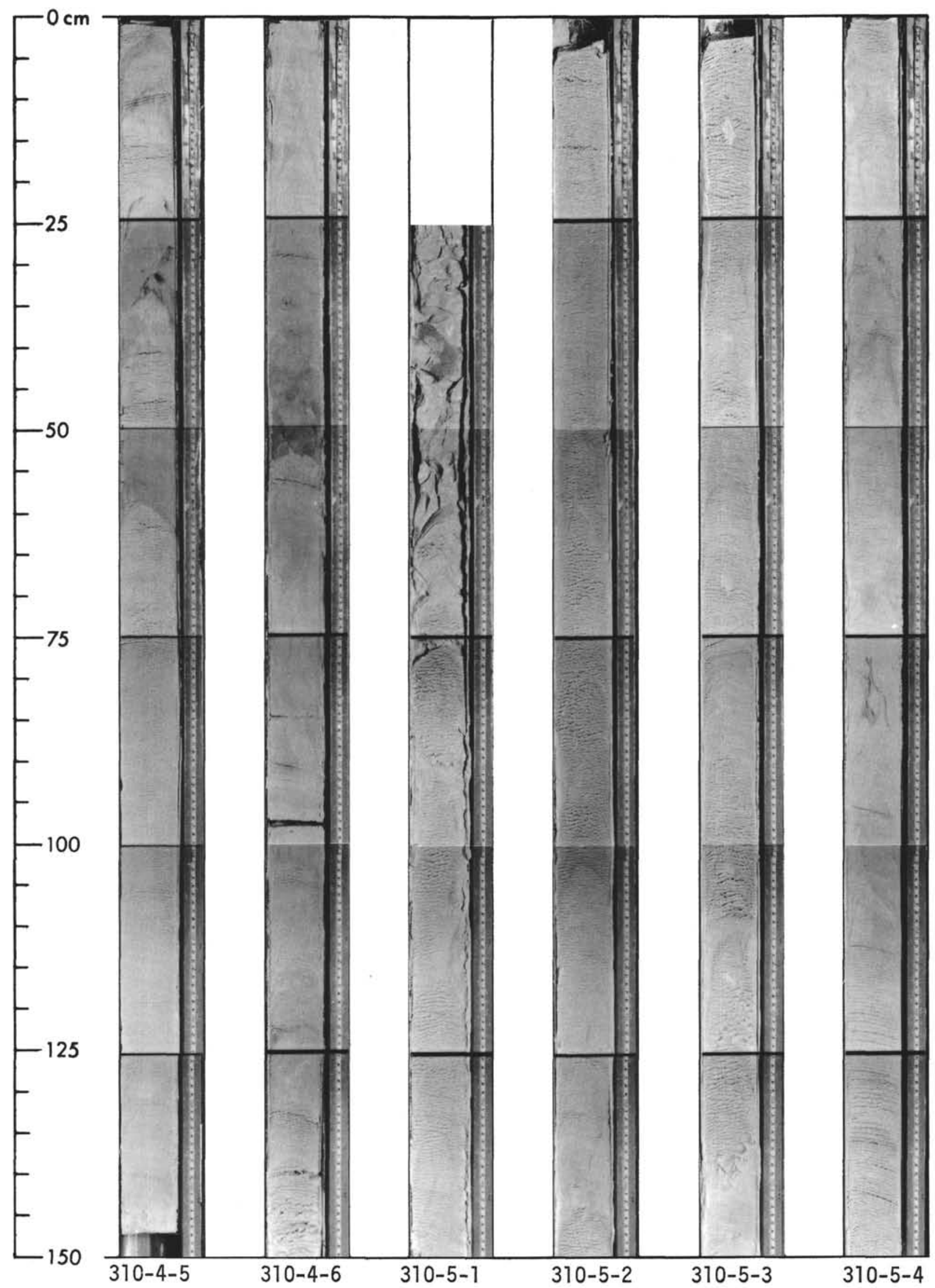


SITE 310

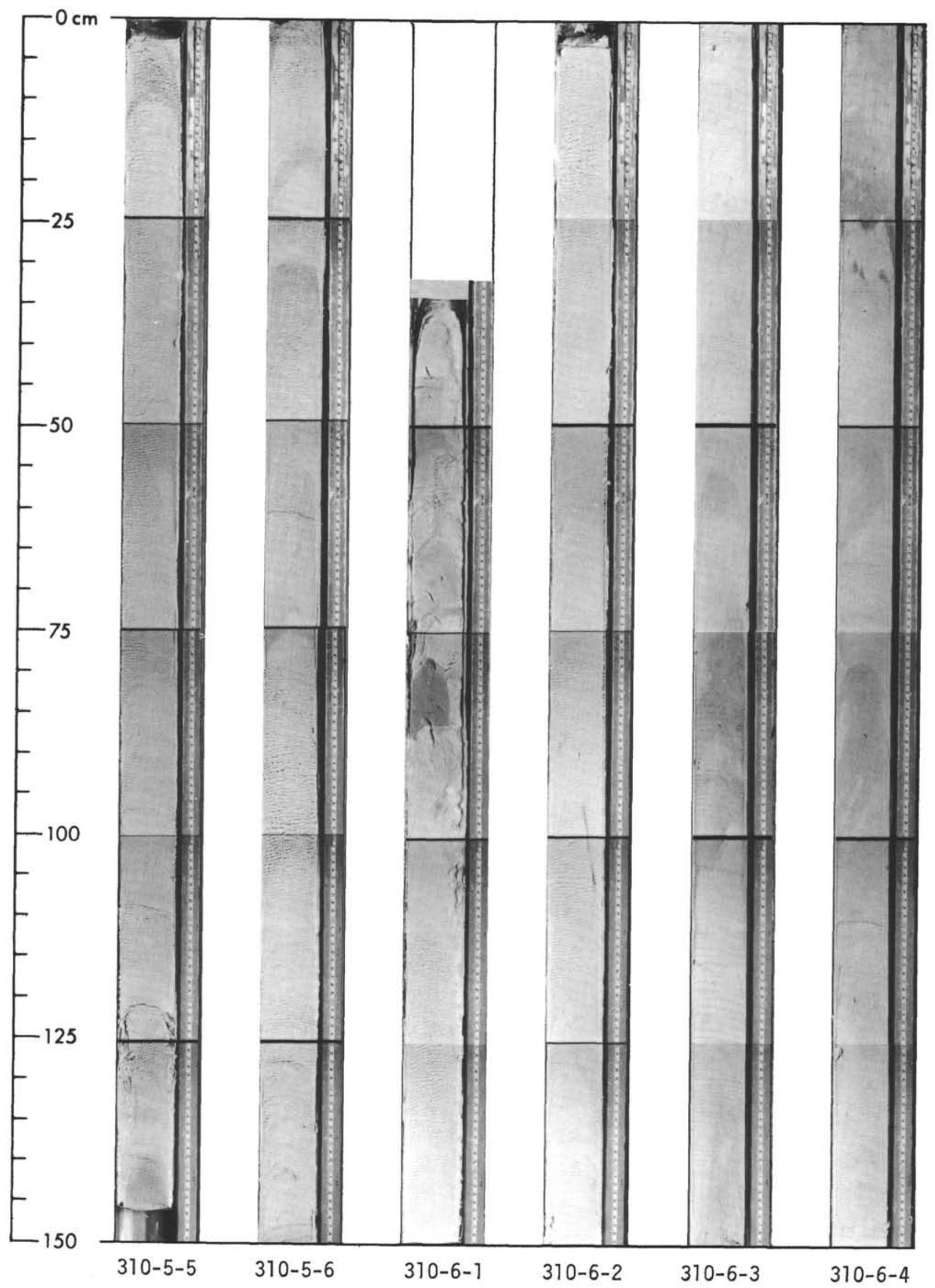




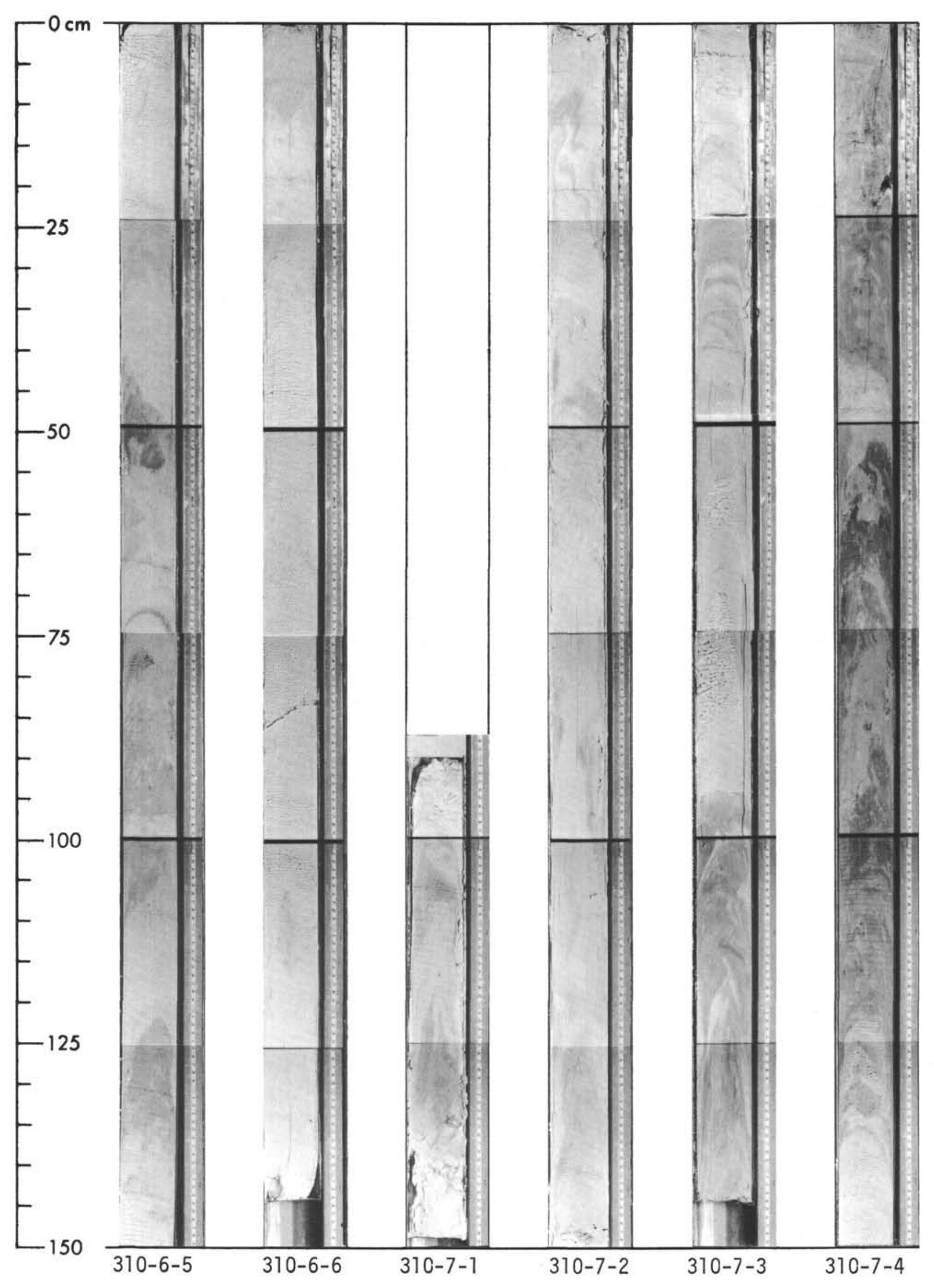




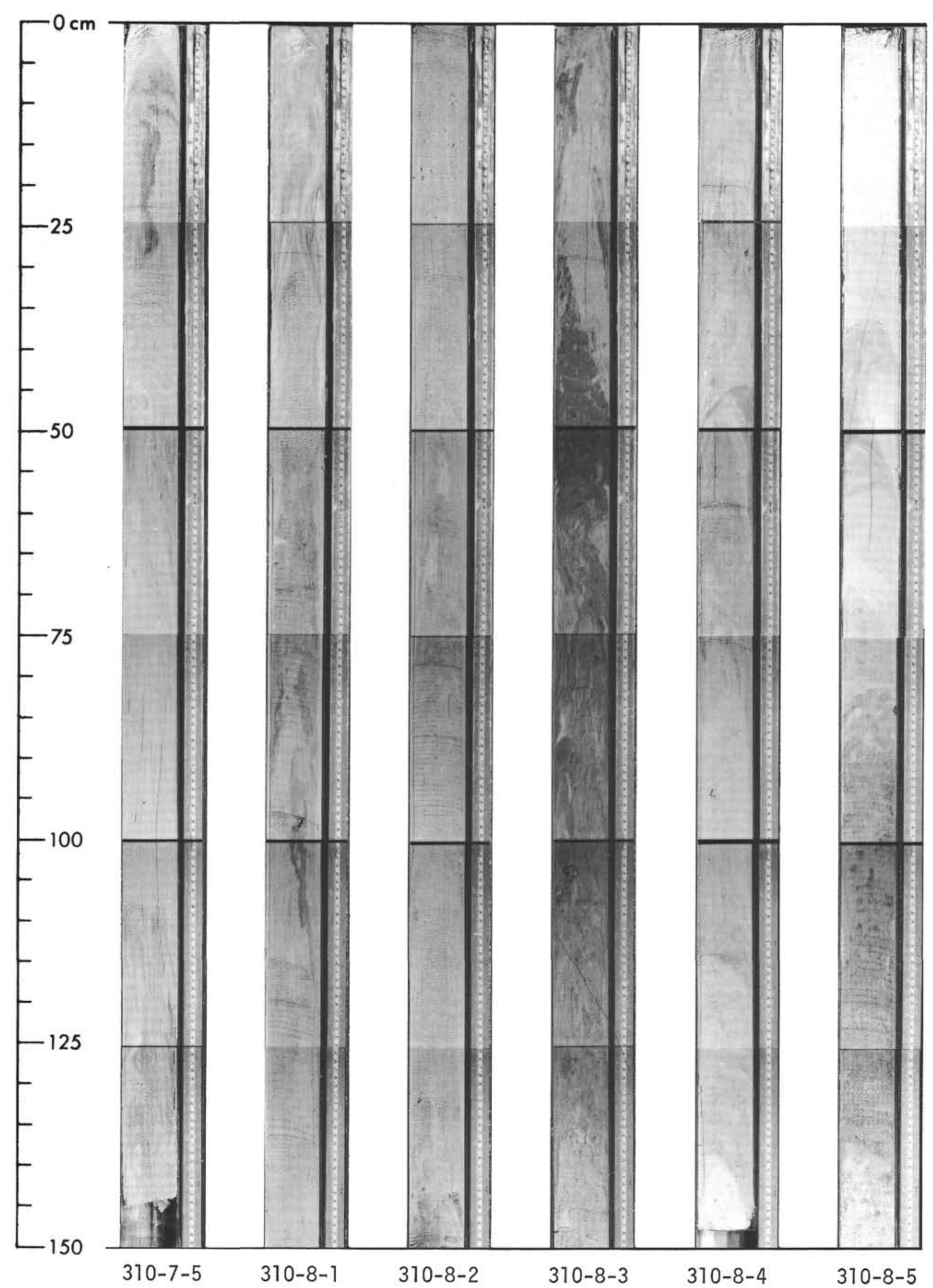




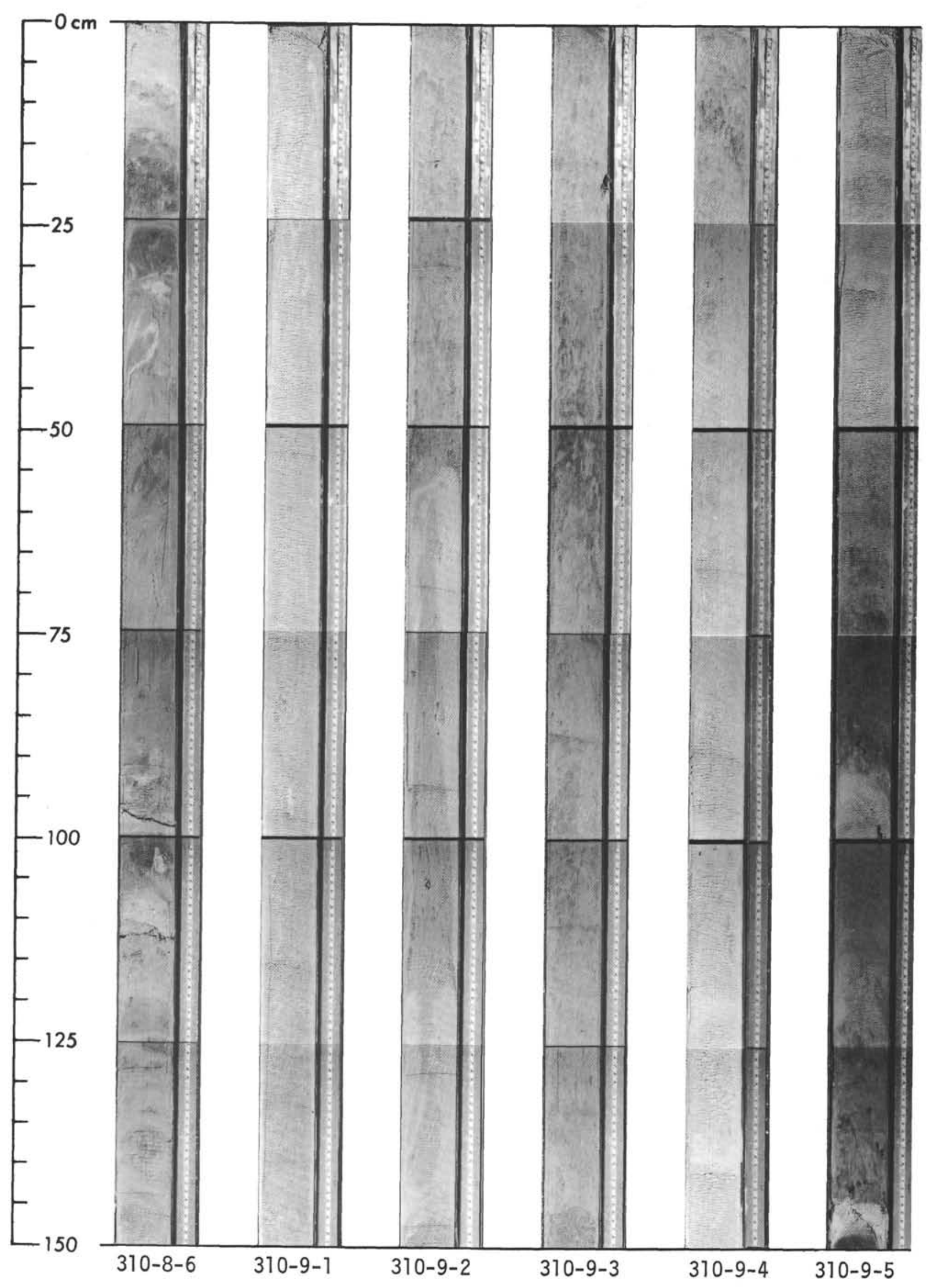


SITE 310

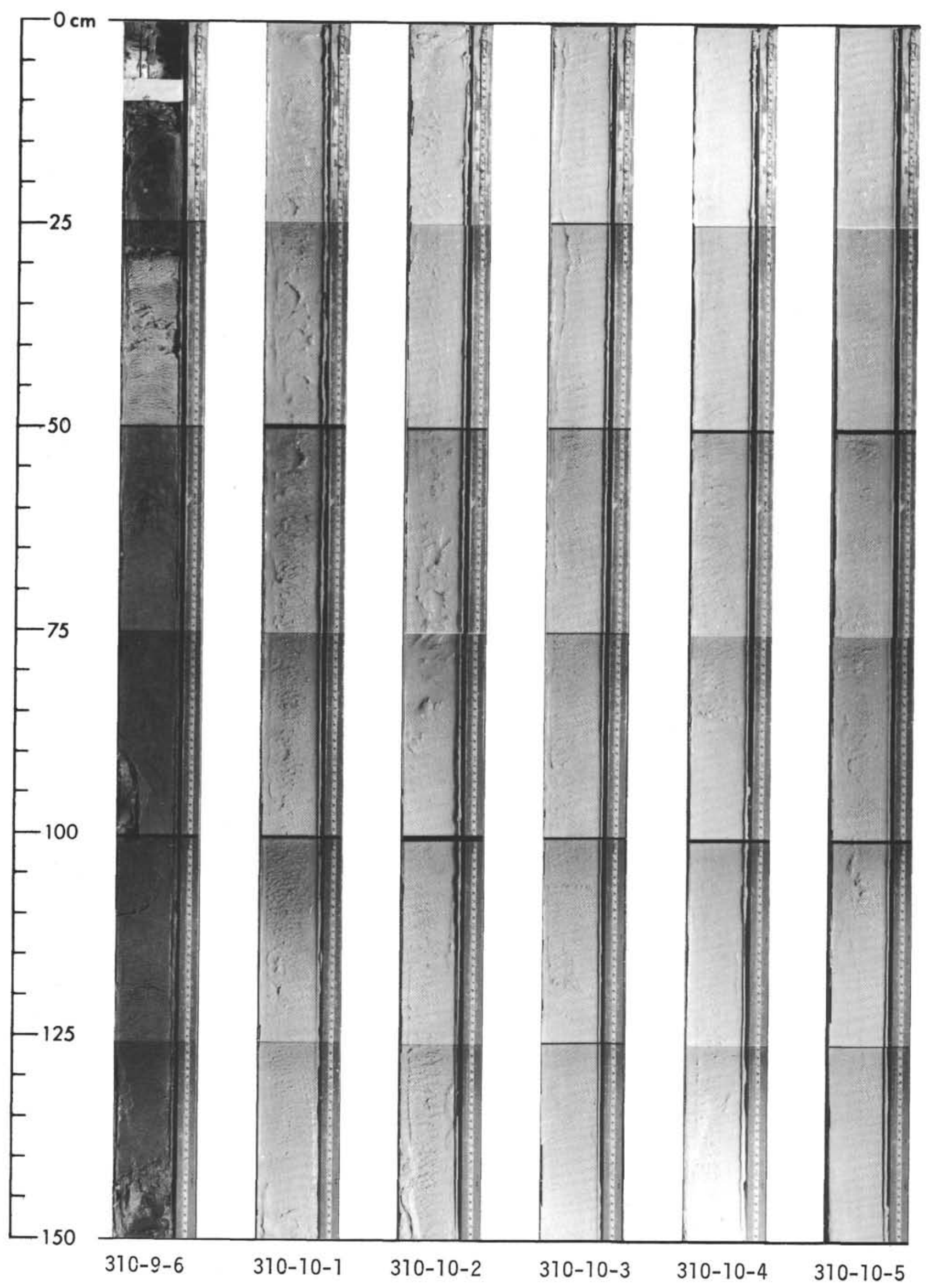




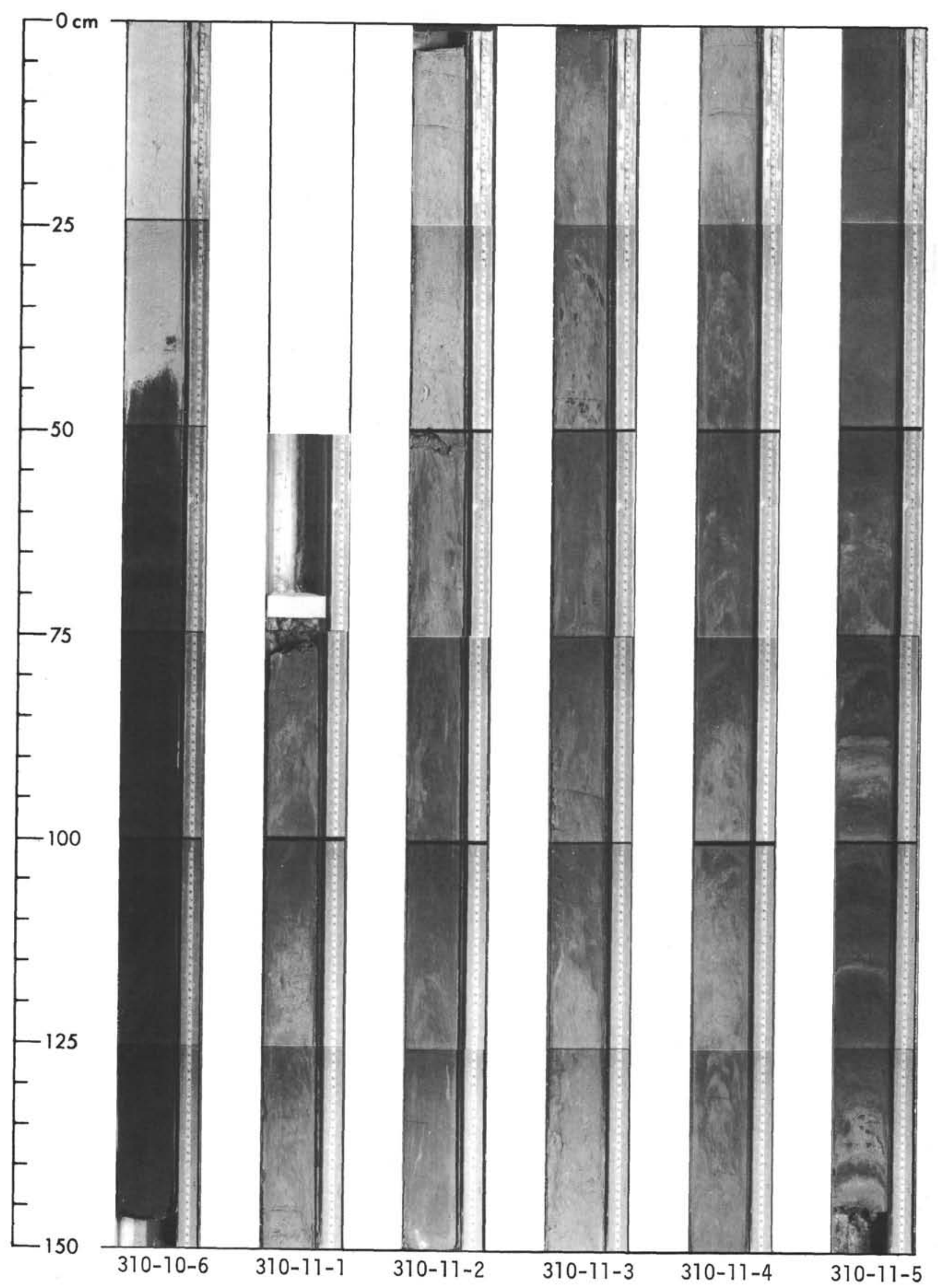




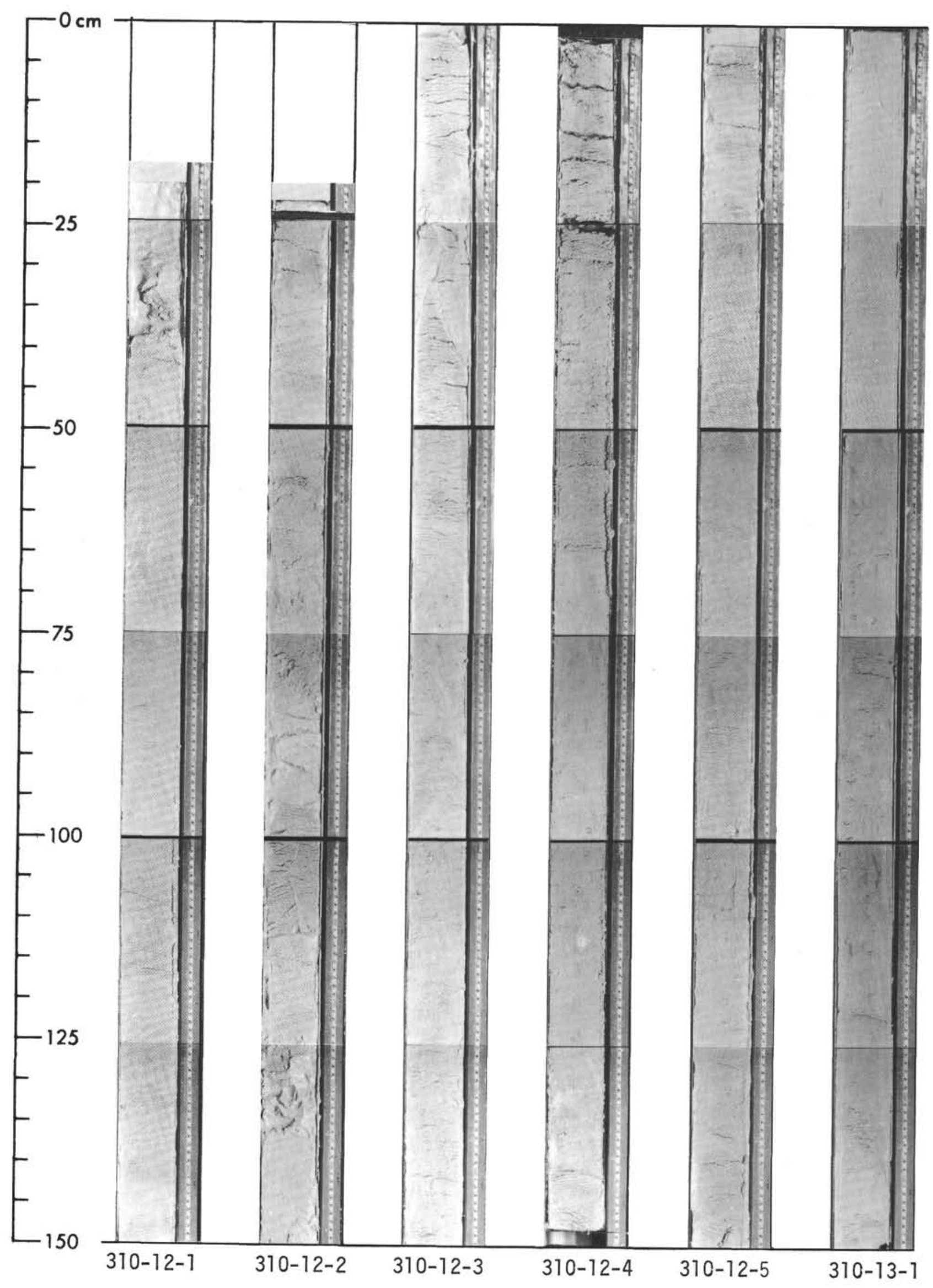




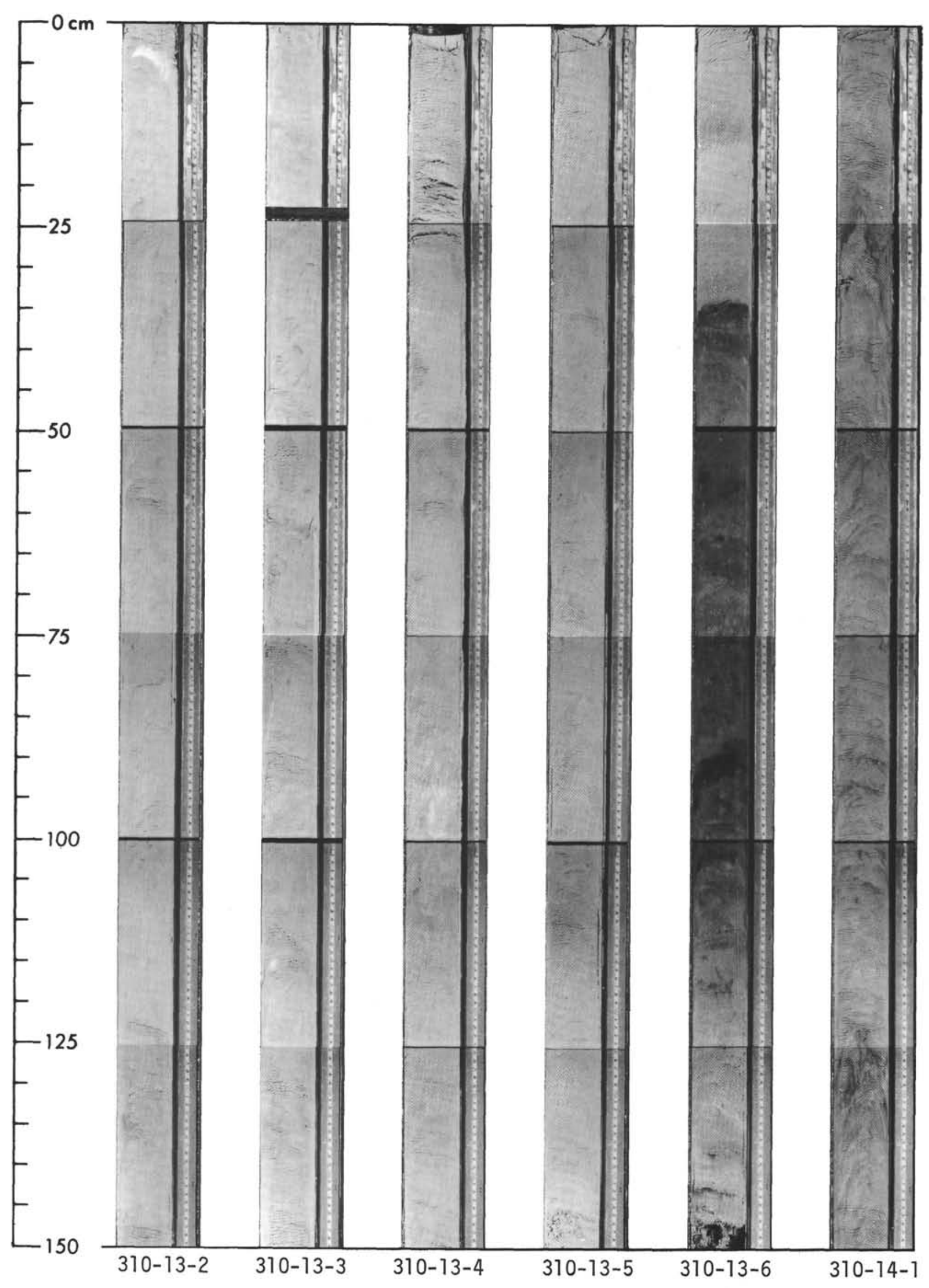




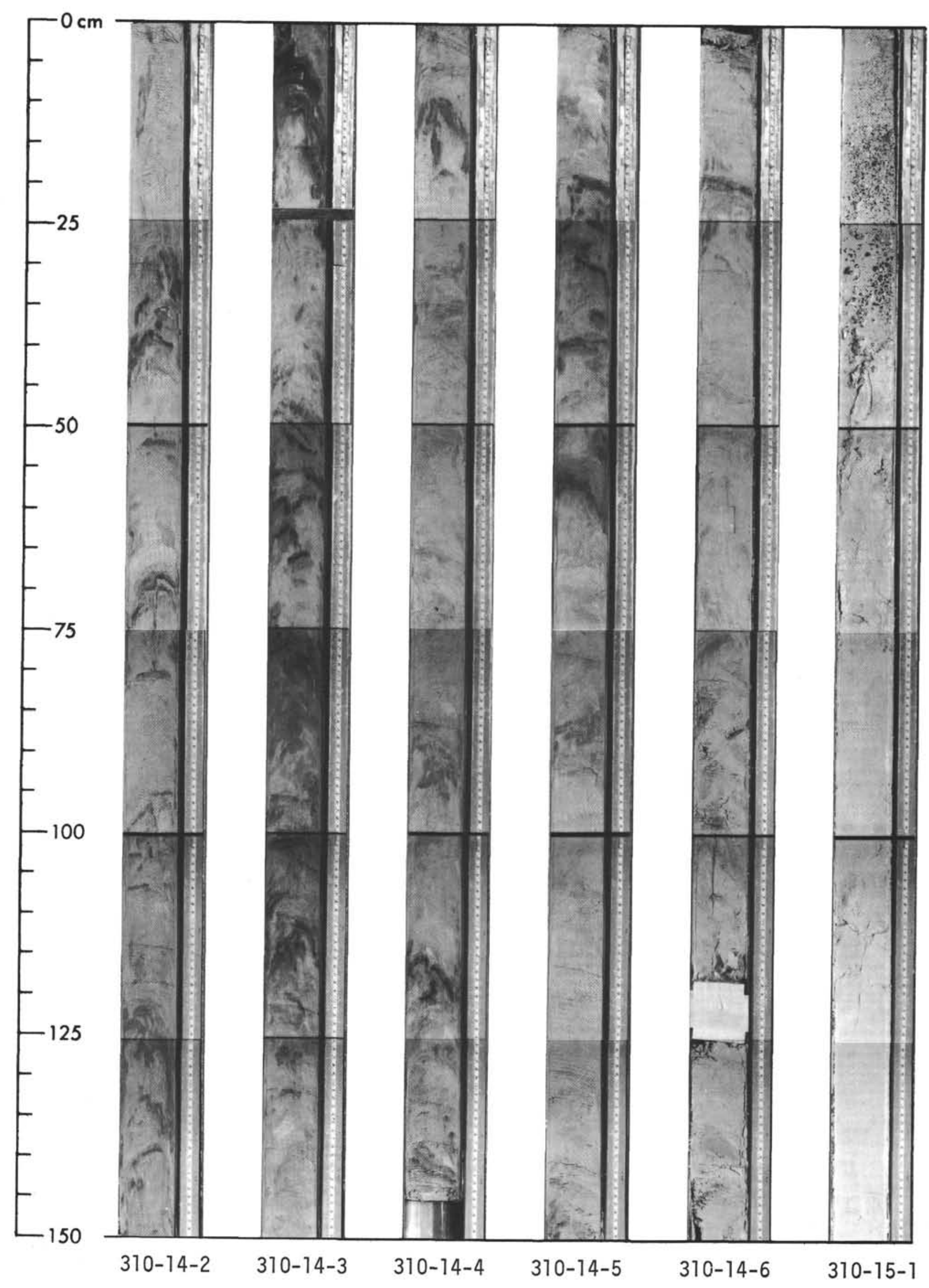




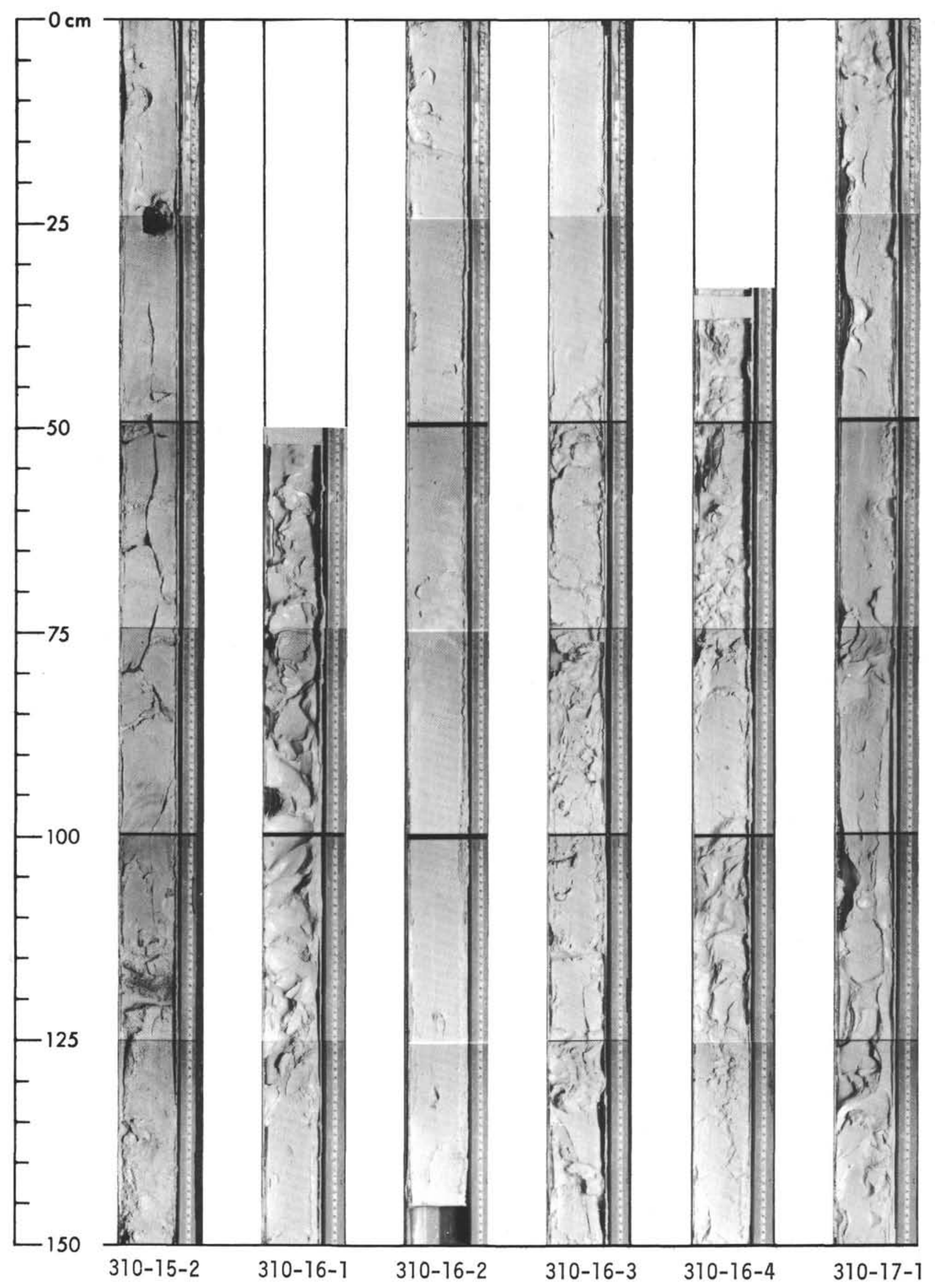




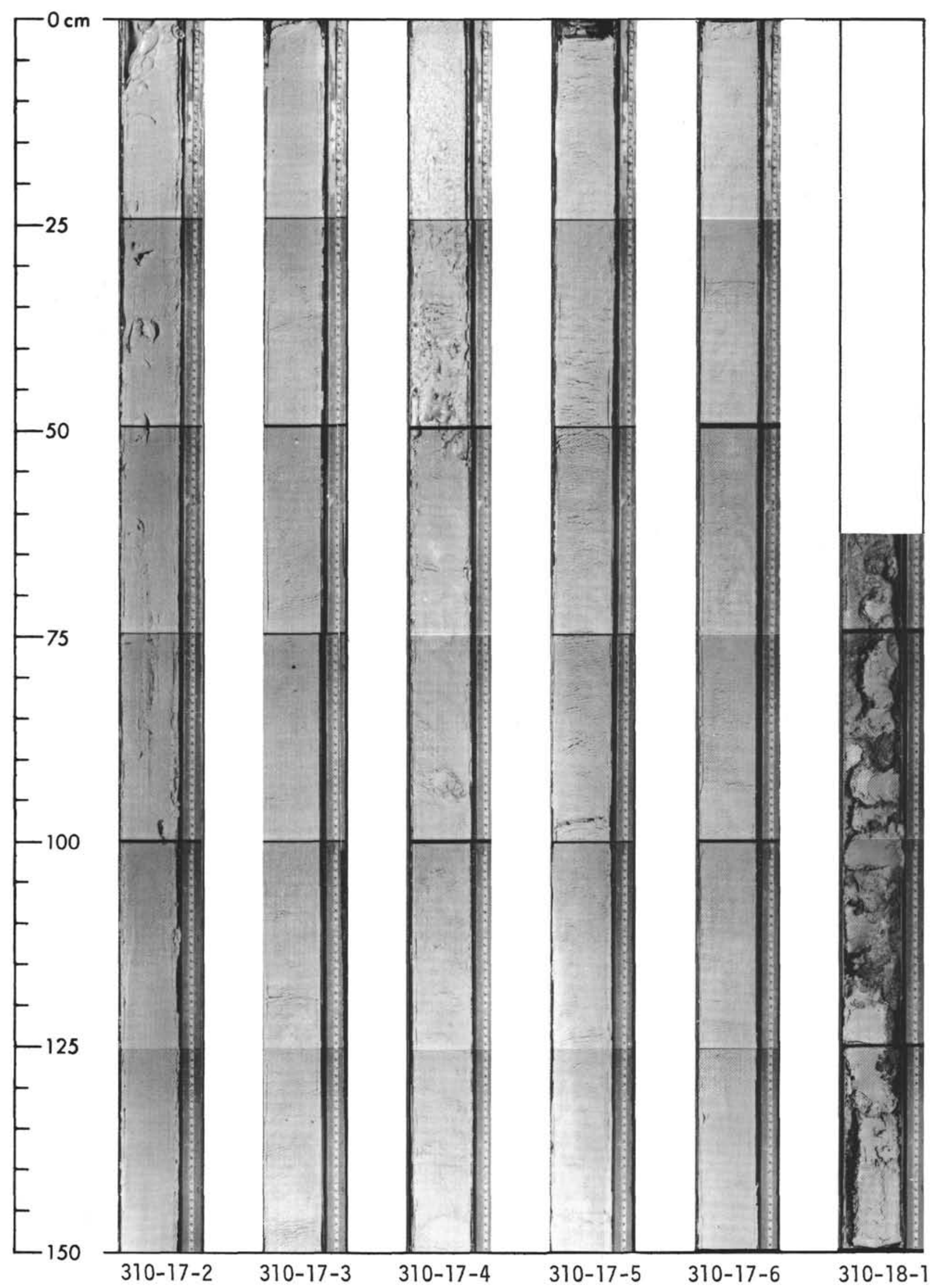




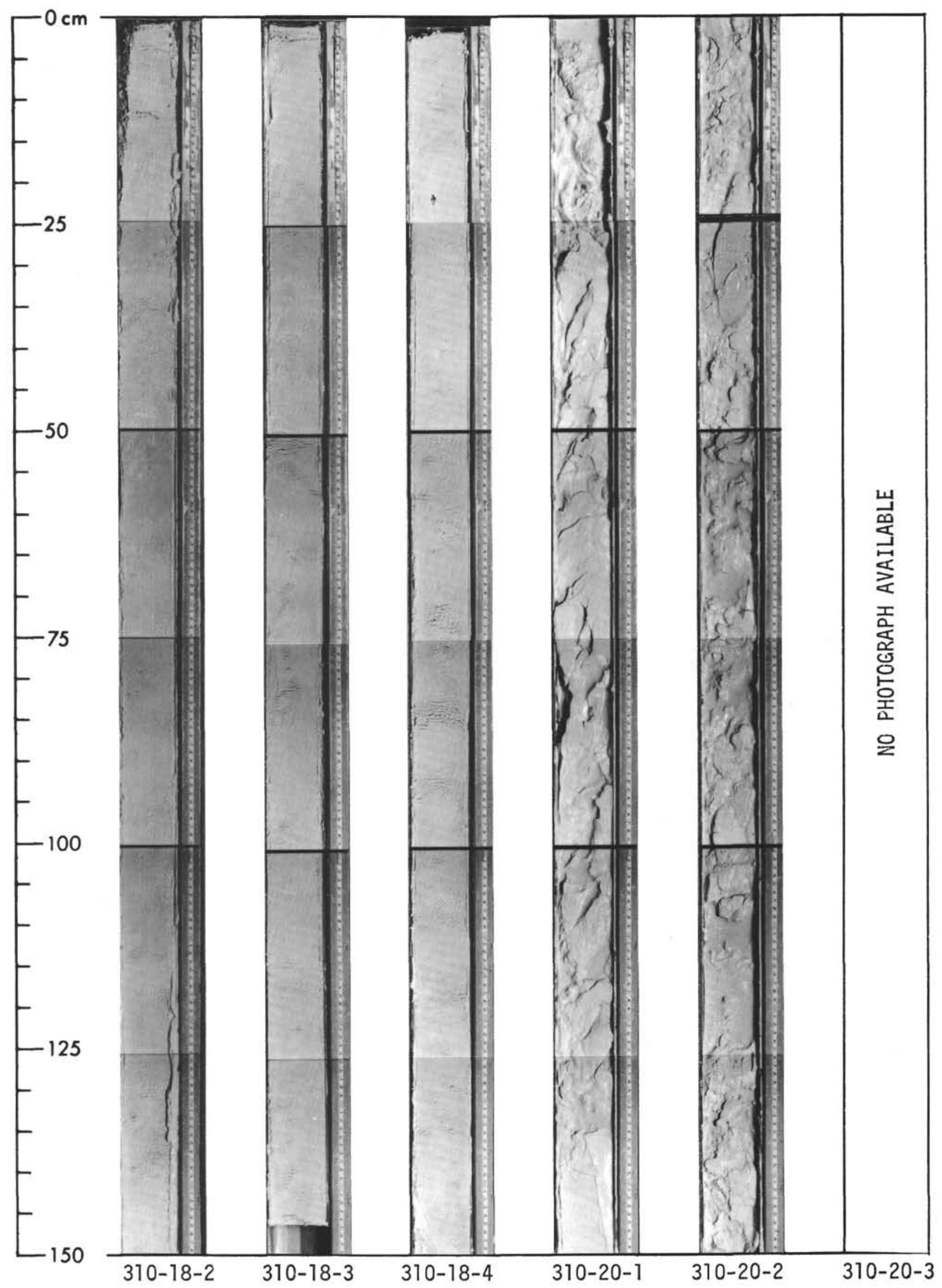




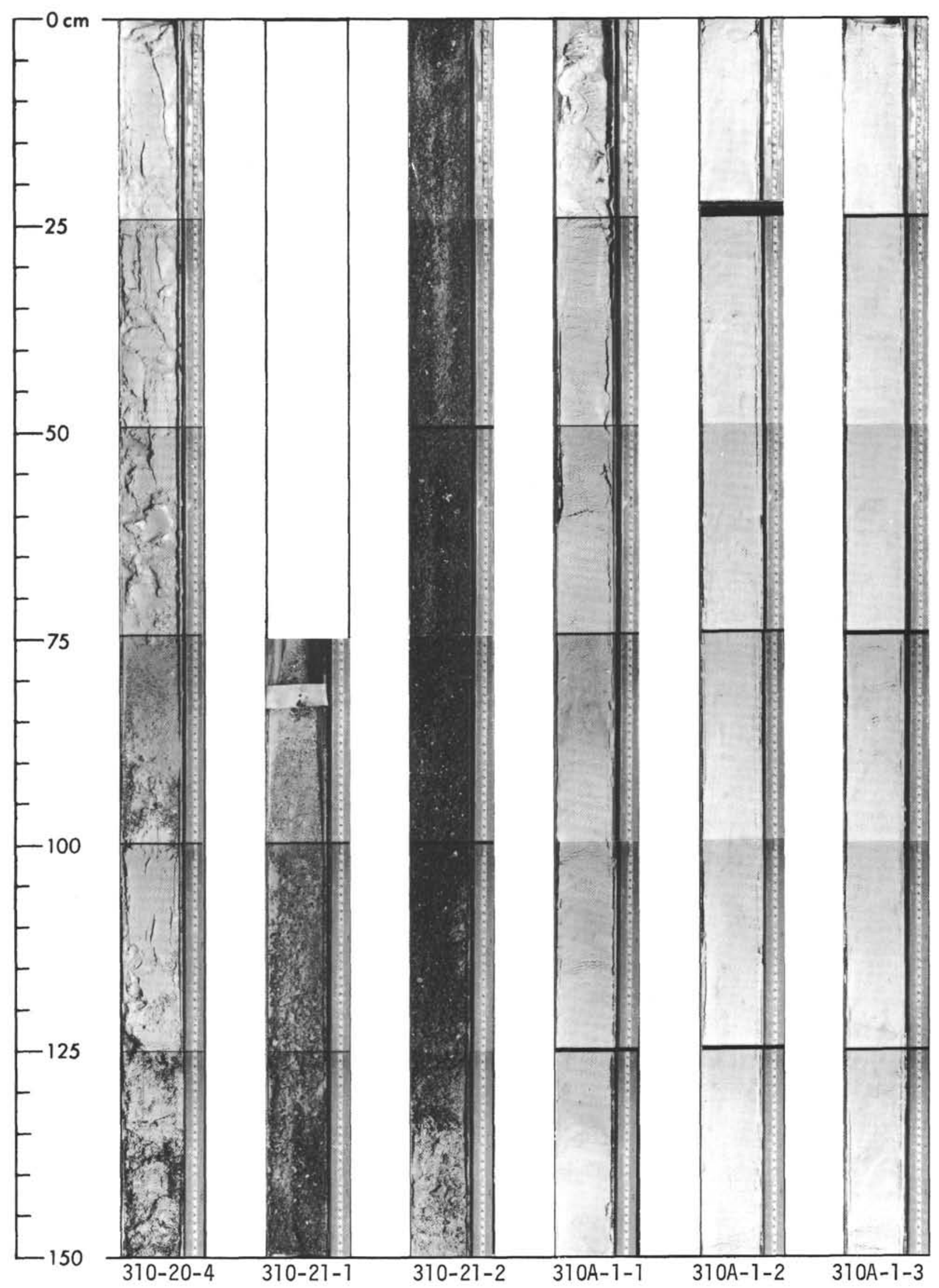




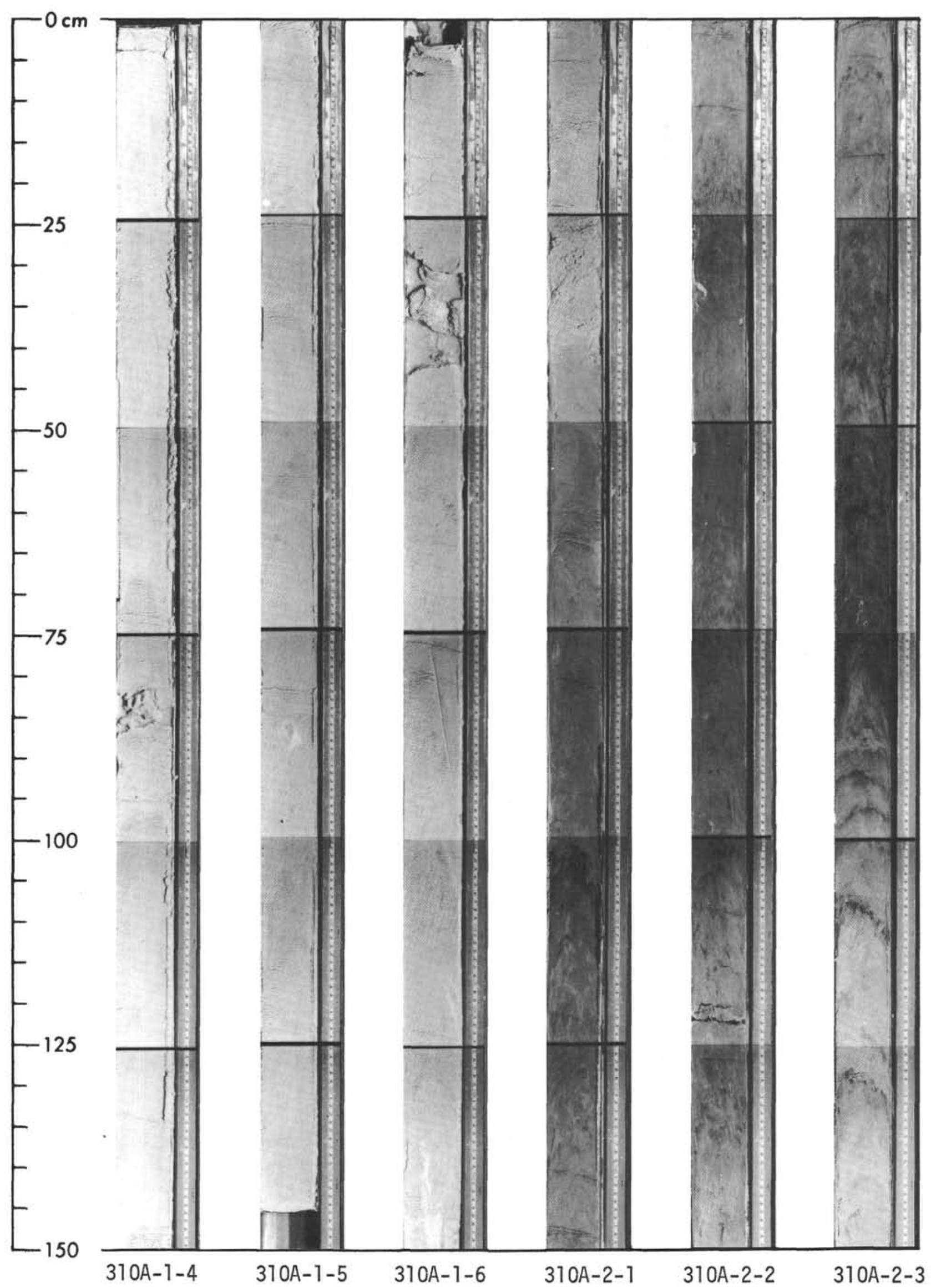




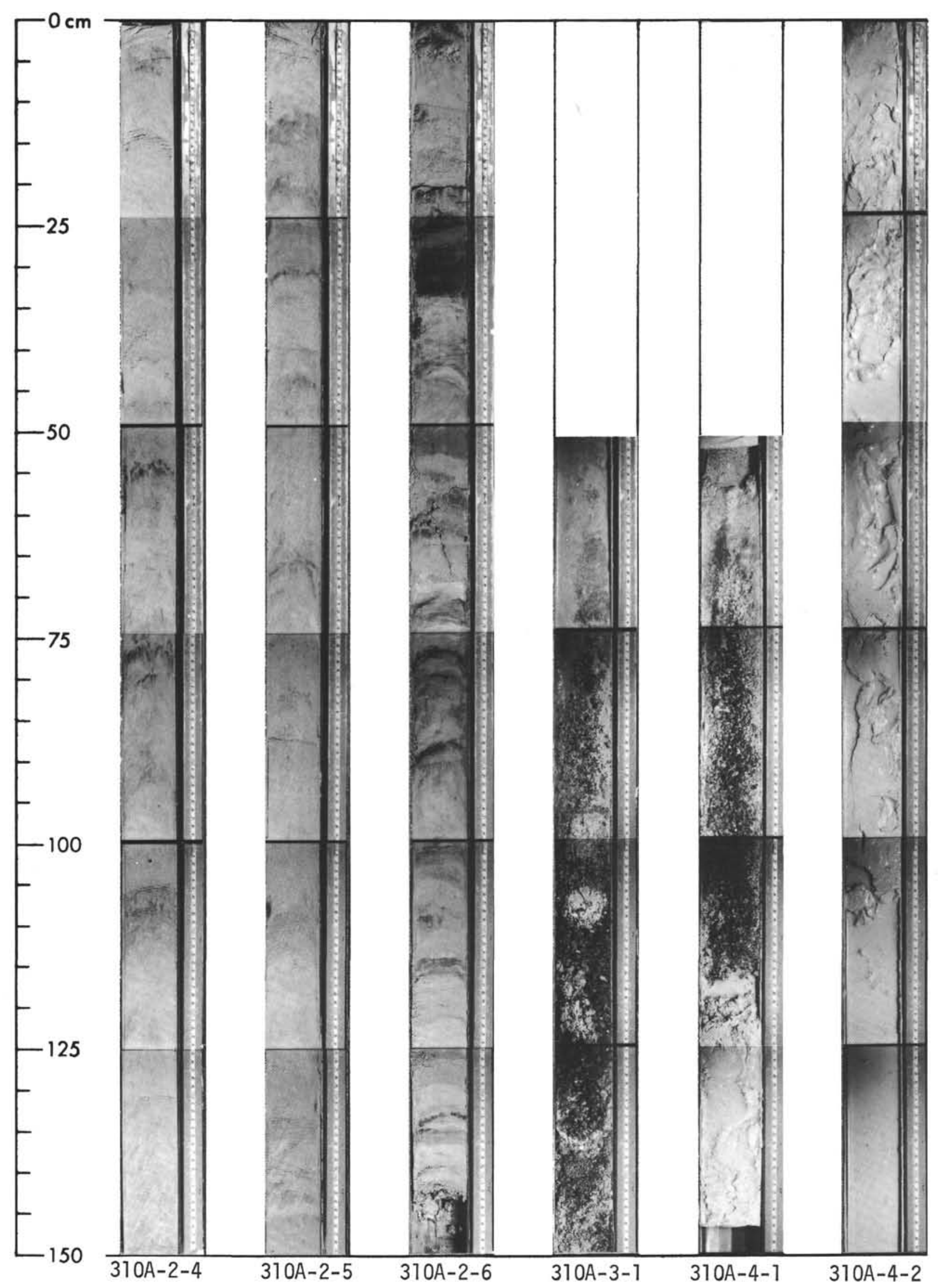




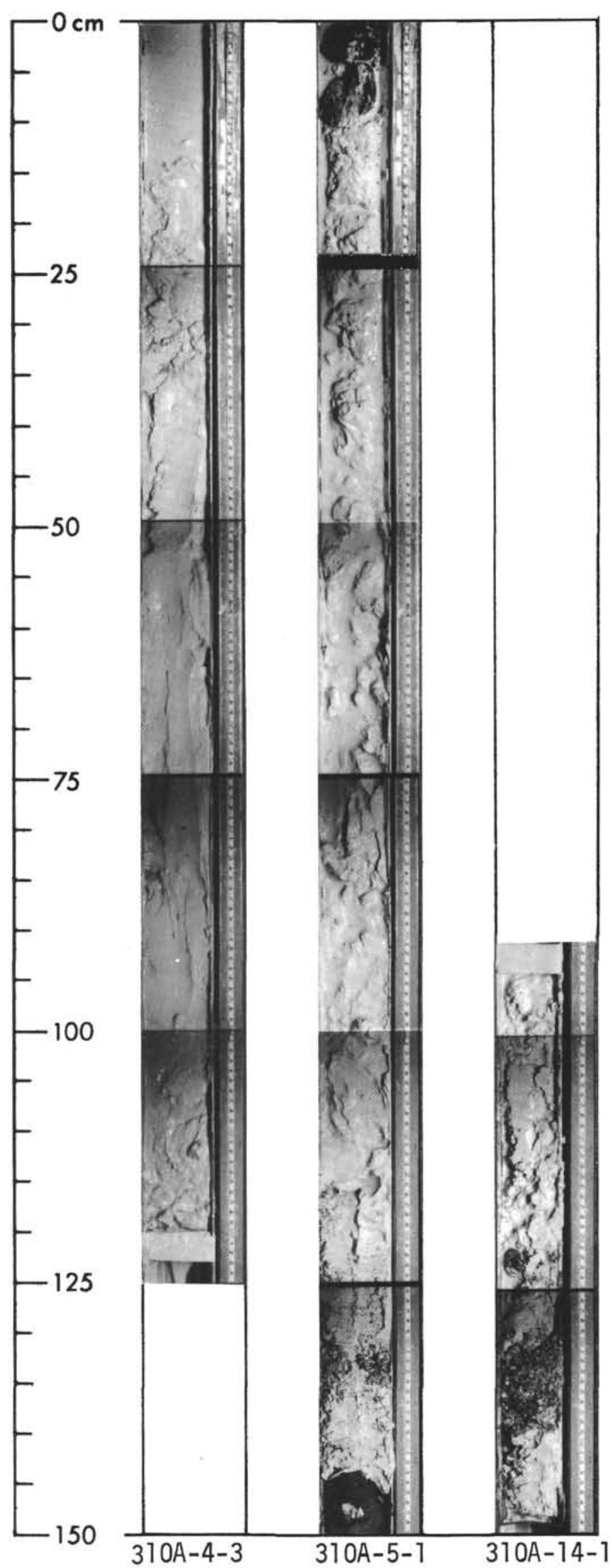

